\title{
Long-acting insulin analogues versus NPH insulin (human isophane insulin) for type 2 diabetes mellitus (Review)
}

Horvath K, Jeitler K, Berghold A, Ebrahim SH, Gratzer TW, Plank J, Kaiser T, Pieber TR, Siebenhofer A

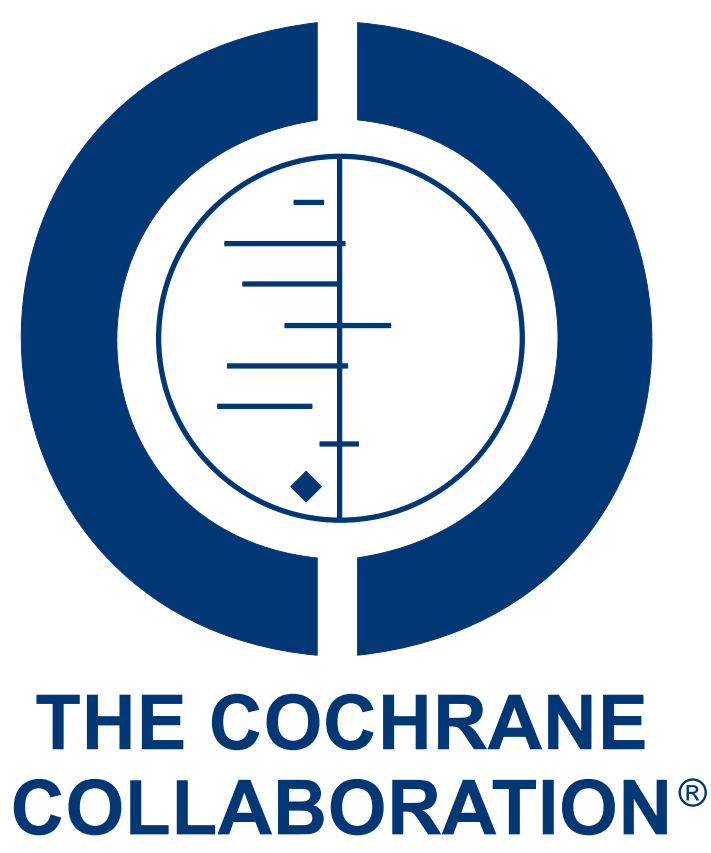

This is a reprint of a Cochrane review, prepared and maintained by The Cochrane Collaboration and published in The Cochrane Library 2007, Issue 2

http://www.thecochranelibrary.com

\section{WILEY}

Long-acting insulin analogues versus NPH insulin (human isophane insulin) for type $\mathbf{2}$ diabetes mellitus (Review)

Copyright @ 2009 The Cochrane Collaboration. Published by John Wiley \& Sons, Ltd. 
TABLE OF CONTENTS

HEADER . . . . . . . . . . . . . . . . . . . . . . . . . . . . . . . . . . . . . . . . 1

ABSTRACT . . . . . . . . . . . . . . . . . . . . . . . . . . . . . . . . . . . . . . . . . . . .

PLAIN LANGUAGE SUMMARY . . . . . . . . . . . . . . . . . . . . . . . . . . . . . . . . . . . . 2

BACKGROUND . . . . . . . . . . . . . . . . . . . . . . . . . . . . . . . . . . . . . .

OBJECTIVES . . . . . . . . . . . . . . . . . . . . . . . . . . . . . . . . . . . . . . . . . . . . .

METHODS . . . . . . . . . . . . . . . . . . . . . . . . . . . . . . . . . . . . . . . 4.4

RESULTS . . . . . . . . . . . . . . . . . . . . . . . . . . . . . . . . . . . . . . . 6

Figure 1. . . . . . . . . . . . . . . . . . . . . . . . . . . . . . . . . . . . . . 47

DISCUSSION . . . . . . . . . . . . . . . . . . . . . . . . . . . . . . . . . . . . .

AUTHORS' CONCLUSIONS . . . . . . . . . . . . . . . . . . . . . . . . . . . . . . . . 16

ACKNOWLEDGEMENTS . . . . . . . . . . . . . . . . . . . . . . . . . . . . . . . . . . . 17

REFERENCES . . . . . . . . . . . . . . . . . . . . . . . . . . . . . . . . . . . . . 17

CHARACTERISTICS OF STUDIES . . . . . . . . . . . . . . . . . . . . . . . . . . . . . . . . . . . . . . .

DATA AND ANALYSES . . . . . . . . . . . . . . . . . . . . . . . . . . . . . . . . . . . . . . . . . . . . . . .

Analysis 1.1. Comparison 1 Hypoglycaemia, Outcome 1 Severe hypoglycaemia - Glargine vs. NPH. . . . . . . . $\quad 32$

Analysis 1.2. Comparison 1 Hypoglycaemia, Outcome 2 Severe hypoglycaemia - Detemir vs. NPH. . . . . . . . 33

Analysis 1.3. Comparison 1 Hypoglycaemia, Outcome 3 Symptomatic hypoglycaemia - Glargine vs. NPH. . . . . . 33

Analysis 1.4. Comparison 1 Hypoglycaemia, Outcome 4 Overall hypoglycaemia - Detemir vs. NPH. . . . . . . 34

Analysis 1.5. Comparison 1 Hypoglycaemia, Outcome 5 Nocturnal hypoglycaemia - Glargine vs. NPH. . . . . . 35

Analysis 1.6. Comparison 1 Hypoglycaemia, Outcome 6 Nocturnal hypoglycaemia - Detemir vs. NPH. . . . . . 35

Analysis 2.1. Comparison 2 HbA1c, Outcome 1 Change in HbA1c - Glargine vs. NPH. . . . . . . . . . . . . 36

Analysis 2.2. Comparison 2 HbA1c, Outcome 2 Change in HbA1c (pooled SD) - Glargine vs. NPH. . . . . . 37

Analysis 2.3. Comparison 2 HbA1c, Outcome 3 Change in HbA1c - Detemir vs. NPH. . . . . . . . . . . . . 38

Analysis 2.4. Comparison 2 HbA1c, Outcome 4 Change in HbA1c (pooled SD) - Detemir vs. NPH. . . . . . . 38

ADDITIONAL TABLES . . . . . . . . . . . . . . . . . . . . . . . . . . . . . . . . . . . . . . . . 38

APPENDICES . . . . . . . . . . . . . . . . . . . . . . . . . . . . . . . . . . . . . . . . . . . . . . . . .

FEEDBACK . . . . . . . . . . . . . . . . . . . . . . . . . . . . . . . . . . . . . . 71

WHAT'S NEW . . . . . . . . . . . . . . . . . . . . . . . . . . . . . . . . . . . . . . 75

HISTORY . . . . . . . . . . . . . . . . . . . . . . . . . . . . . . . . . . . . . . . 76

CONTRIBUTIONS OF AUTHORS . . . . . . . . . . . . . . . . . . . . . . . . . . . . . . . . . . . . . . . 76

DECLARATIONS OF INTEREST . . . . . . . . . . . . . . . . . . . . . . . . . . . . . . . . 76

SOURCES OF SUPPORT . . . . . . . . . . . . . . . . . . . . . . . . . . . . . . . . . . . . . . 76

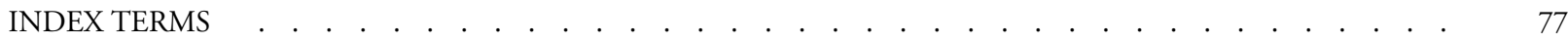

Long-acting insulin analogues versus NPH insulin (human isophane insulin) for type 2 diabetes mellitus (Review)

Copyright $\odot 2009$ The Cochrane Collaboration. Published by John Wiley \& Sons, Ltd. 


\title{
[Intervention Review]
}

\section{Long-acting insulin analogues versus NPH insulin (human isophane insulin) for type 2 diabetes mellitus}

\author{
Karl Horvath ${ }^{1}$, Klaus Jeitler ${ }^{1}$, Andrea Berghold ${ }^{2}$, Susanne H Ebrahim ${ }^{3}$, Thomas W Gratzer ${ }^{4}$, Johannes Plank ${ }^{1}$, Thomas Kaiser ${ }^{5}$, \\ Thomas R Pieber ${ }^{1}$, Andrea Siebenhofer ${ }^{6}$ \\ ${ }^{1}$ Department of Internal Medicine, Medical University of Graz, Graz, Austria. ${ }^{2}$ Institute for Medical Informatics, Statistics and \\ Documentation, Medical University of Graz, Graz, Austria. ${ }^{3}$ Institute for Quality and Efficiency in Health Care, Cologne, Germany. \\ ${ }^{4}$ Department of Internal Medicine, Medical University Graz, Graz, Austria. ${ }^{5} \mathrm{IQWiG}$, Koln, Germany. ${ }^{6}$ Department of Internal \\ Medicine and Institute for Medical Informatics, Statistics and Documentation, Medical University of Graz, Graz, Austria
}

Contact address: Karl Horvath, Department of Internal Medicine, Medical University of Graz, Auenbruggerplatz 15, Graz, 8036, Austria. horvath.karl@klinikum-graz.at.

Editorial group: Cochrane Metabolic and Endocrine Disorders Group.

Publication status and date: Edited (no change to conclusions), published in Issue 4, 2009.

Review content assessed as up-to-date: 10 December 2006.

Citation: Horvath K, Jeitler K, Berghold A, Ebrahim SH, Gratzer TW, Plank J, Kaiser T, Pieber TR, Siebenhofer A. Long-acting insulin analogues versus NPH insulin (human isophane insulin) for type 2 diabetes mellitus. Cochrane Database of Systematic Reviews 2007, Issue 2. Art. No.: CD005613. DOI: 10.1002/14651858.CD005613.pub3.

Copyright (C) 2009 The Cochrane Collaboration. Published by John Wiley \& Sons, Ltd.

\begin{abstract}
A B S T R ACT
Background

Despite indications from epidemiological trials that higher blood glucose concentrations are associated with a higher risk for developing micro- and macrovascular complications, evidence for a beneficial effect of antihyperglycaemic therapy in patients with type 2 diabetes mellitus is conflicting. Two large studies, the United Kingdom Prospective Diabetes Study (UKPDS) and the University Group Diabetes Program (UGDP), did not find a reduction of cardiovascular endpoints through improvement of metabolic control. The theoretical benefits of newer insulin analogues might result in fewer macrovascular and microvascular events.
\end{abstract}

Objectives

To assess the effects of long-term treatment with long-acting insulin analogues (insulin glargine and insulin detemir) compared to NPH insulin in patients with type 2 diabetes mellitus.

\section{Search methods}

Studies were obtained from computerised searches of MEDLINE, EMBASE, The Cochrane Library and communication with experts in the field as well as insulin producing companies.

\section{Selection criteria}

Studies were included if they were randomised controlled trials in adults with diabetes mellitus type 2 and had a trial duration of at least 24 weeks.

\section{Data collection and analysis}

Two authors independently assessed trial quality and extracted data. Pooling of studies by means of random-effects meta-analyses was performed.

Long-acting insulin analogues versus NPH insulin (human isophane insulin) for type 2 diabetes mellitus (Review)

Copyright (c) 2009 The Cochrane Collaboration. Published by John Wiley \& Sons, Ltd. 


\section{Main results}

Six studies comparing insulin glargine to NPH (Neutral Protamine Hagedorn) insulin and two studies comparing insulin detemir to $\mathrm{NPH}$ insulin were identified. In these trials, 1715 patients were randomised to insulin glargine and 578 patients to insulin detemir. Duration of the included trials ranged from 24 to 52 weeks. Metabolic control, measured by glycosylated haemoglobin A1c (HbA1c) as a surrogate endpoint, and adverse effects did not differ in a clinical relevant way between treatment groups. While no statistically significant difference for severe hypoglycaemia rates was shown in any of the trials, the rate of symptomatic, overall and nocturnal hypoglycaemia was statistically significantly lower in patients treated with either insulin glargine or detemir. No evidence for a beneficial effect of long-acting analogues on patient-oriented outcomes like mortality, morbidity, quality of life or costs could be obtained.

\section{Authors' conclusions}

Our analysis suggests, if at all only a minor clinical benefit of treatment with long-acting insulin analogues for patients with diabetes mellitus type 2 treated with "basal" insulin regarding symptomatic nocturnal hypoglycaemic events. Until long-term efficacy and safety data are available, we suggest a cautious approach to therapy with insulin glargine or detemir.

\section{PLAIN LANGUAGE SUMMARY}

\section{Long acting insulin analogues versus NPH insulin (human isophane insulin) for type 2 diabetes mellitus}

NPH (Neutral Protamine Hagedorn) insulin is the current standard for basal insulin in the blood glucose lowering therapy in people with type 2 diabetes mellitus. The mode of action of this insulin is highly variable, which may be the cause for the difficulties some people with diabetes have to achieve current goals for long-term metabolic control. Therefore, new insulins which are thought to show more favourable properties of action have been developed: insulin glargine and insulin detemir. Because of their theoretical advantages, it is thought that treatment with these new insulin analogues might lead to a beneficial effect, for example less hypoglycaemia or a better metabolic control, possibly resulting in higher quality of life and treatment satisfaction less late diabetic complications such as problems with eyes, kidneys or feet and myocardial infarction, stroke or death.

Although epidemiological studies indicate that high concentrations of blood glucose carry a higher risk for these late complications, evidence for a beneficial effect of glucose-lowering therapy is conflicting. Following from the different results of large clinical trials, interventions seem to carry different substance specific beneficial or adverse effects. As a consequence, conclusions on the effects of different blood glucose lowering interventions on these outcomes can not be drawn from their effect on blood glucose concentration alone.

Methodological quality of all the studies was rated low (“C”). Eight studies investigated altogether 2293 people. Trials lasted between 24 and 52 weeks. Our analysis of the currently available long-term trials comparing long acting insulin analogues with NPH insulin showed that insulin glargine and insulin detemir were almost identically effective compared to NPH insulin in long-term metabolic control (HbAlc). Fewer people experienced symptomatic overall or nocturnal hypoglycaemic episodes with treatment with either of the two analogues. No conclusive information on late complications or on possible differences in the number of fatalities exists. For insulin glargine one study found a higher rate of progression of diabetic retinopathy in patients treated with insulin glargine, while in another investigation the opposite result was found. It was thus not possible to conclude for certain whether insulin glargine treatment is safe or not. From the retrieved trials it was also not possible to draw firm conclusions on the effects of these new insulins on quality of life or their cost effectiveness. Until long-term data on benefit and risk are available, we suggest a cautious approach to treatment with insulin glargine or insulin detemir.

\section{Description of the condition}

Diabetes mellitus type 2 is a metabolic disorder characterised by relative insulin deficiency resulting from a reduced sensitivity of 
tissues to insulin or an impairment of insulin secretion by pancreatic beta cells or both. This in turn leads to chronic hyperglycaemia (that is elevated levels of plasma glucose) with disturbances of carbohydrate, fat and protein metabolism. Long-term complications of diabetes mellitus include retinopathy, nephropathy, neuropathy and increased risk of cardiovascular disease. For a detailed overview of diabetes mellitus, please see 'Additional information' in the information on the Metabolic and Endocrine Disorders Group in The Cochrane Library (see 'About the Cochrane Collaboration', 'Collaborative Review Groups (CRGs)'). For an explanation of methodological terms, see the main Glossary in The Cochrane Library.

\section{Description of the intervention}

Even though epidemiological investigations indicate that higher blood glucose concentrations are associated with a higher risk for developing micro- and macrovascular complications (Adler 1997; Klein 1995; Turner 1998), evidence for a beneficial effect of antihyperglycaemic therapy is conflicting. In the past, investigations of different pharmacological interventions showed results from a marked risk reduction of microvascular complications (Ohkubo 1995), a reduction of macrovascular risk without a difference in blood glucose concentrations (UKPDS 34 1998) to a statistically non significant (Abraira 1997) and even statistically significant (UKPDS 34 1998) risk increase for macrovascular complications. Following from these results, it has to be assumed that the different interventions carry different substance specific beneficial or adverse effects. As a consequence, firm conclusions on the effect of interventions on patient-relevant outcomes can not be drawn from the effect of these interventions on blood glucose concentration alone.

Pharmacological anti-hyperglycaemic therapy in patients with type 2 diabetes mellitus can be done either by different oral agents or insulin. Insulin in itself is a group of heterogeneous preparations clinically differentiated by their course of action over time. While short-acting insulin is used to mimic the response of endogenous insulin to food intake and to correct pre- or betweenmeal hyperglycaemia (bolus insulin), intermediate and long-acting insulin is primarily used to provide a continuous supply of small amounts of insulin, independent of food intake, over a longer period of time to regulate lipolysis and the output of hepatic glucose (basal insulin). long-acting insulin preparations are obtained by crystallisation with either protamine (NPH type) or zinc (Lente type). Treatment with these basal insulins however does show some drawbacks. Achieving lower blood glucose levels carries an increased risk for hypoglycaemia. Because NPH, the most widely used basal insulin, is associated with a pronounced insulin peak following injection and variable absorption (Heinemann 2000; Lepore 2000), targeting for lower glycosylated haemoglobin A1c (HbA1c) levels is often difficult and leads to an increased rate of hypoglycaemic events.
In an effort to provide insulin with a more physiological time course of action to patients with diabetes mellitus, so called insulin analogues have been developed. Insulin analogues are insulin-like molecules, engineered on the basis of the human insulin molecular structure by changing the amino acid sequence and the physiochemical properties. Two such long-acting insulin analogues, insulin detemir (Levemir $\left.{ }^{\circledR}\right)$ and insulin glargine (Lantus $\left.{ }^{\circledR}\right)$ are currently available on the market.

Based on the altered time-action profiles of these insulin analogues, different possible advantages in the therapy of diabetic patients were suggested. For instance it was proposed that a lower HbA1c could be achieved with a simultaneous lower risk of hypoglycaemia due to the longer action (lower fasting plasma glucose) and the less pronounced peak (less hypoglycaemia especially during the night). It was also hypothesised that use of Insulin glargine or detemir could improve the patient's quality of life and treatment satisfaction.

\section{Adverse effects of the intervention}

Comparing human insulin with insulin analogues has shown a higher mitogenic potency and IGF binding affinity for some representatives of the group of insulin analogues in in-vitro and animal studies (Grant 1993; Jorgensen 1992; King 1985; Kurtzhals 2000). These effects differ among the individual insulin analogues and results provided from these studies cannot clarify the relevance for patients with diabetes mellitus. The American and the European pharmaceutical registration agencies FDA and EMEA (EMEA 2003; EMEA 2004; FDA 2000; FDA 2005) have commented on the mitogenic and carcinogenic potency of long-acting insulin analogues and conclude that the detrimental effects seems to be low. However, it must be noted that the clinical relevance for patients remains unknown.

\section{How the intervention might work}

Insulin glargine is produced by substituting glycine for asparagine at position 21 of the A-region of the insulin molecule and the addition of two arginine molecules at position B30. This leads to a shift of the isoelectric point toward a neutral $\mathrm{pH}$, resulting in a molecule which is less soluble at the injection site and forms an amorphous precipitate in the subcutaneous tissue which is gradually absorbed. From this depot insulin molecules are slowly released. Metabolic activity of insulin glargine has been shown in pharmacodynamic studies to last for 22 (Lepore 2000) and 30 (Heinemann 2000) hours and to have no peak (Lepore 2000). Different from this time course of action, NPH insulin, currently the most widely used basal-insulin, reaches a peak between four and eight hours with a duration of action of 12 to 14 hours (Lepore 2000). Variation among study participants in the rates of glucose infusion required to maintain euglycaemia after injection has also 
been found to be lower with insulin glargine than with both NPH and zinc insulin (Lepore 2000).

Compared to human insulin, the amino acid threonin at position 30 of the B-region has been omitted and a fatty acid acylated to lysin at position B 29 in insulin detemir. These modifications lead to a self association at the injection site and allow insulin detemir to reversibly bind to the fatty acid binding sites of albumin. Both of these mechanisms seem to be responsible for the slow absorption from the subcutaneous tissue and thus the protracted action of this insulin analogue (Havelund 2004). Also, euglycaemic clamp studies in type 1 diabetic patients showed a lower degree of intra patient variability of action compared with NPH insulin and insulin glargine (Heise 2004).

\section{Why it is important to do this review}

Several publications have evaluated the clinical efficacy of insulin glargine and insulin detemir in the treatment of patients with type 2 diabetes mellitus. Also, various reviews on this subject have been conducted. These reviews considered either only glargine (CCOHTA Glargine 2004; Dunn 2003; National 2002; Rosenstock 2005) or insulin detemir (CCOHTA Detemir 2004; Chapman 2004) or were published before new studies on these new insulin analogues became available.

While from their pharmacokinetic profile, long-acting insulin analogues appear to be an improvement in the insulin therapy of patients with diabetes mellitus, their superiority in the clinical setting has still to be proven. The aim of this work is to systematically review the clinical efficacy and safety of insulin glargine and detemir in the treatment of patients with type 2 diabetes mellitus.

\section{O B J E C T I VES}

To assess the effects of long-term treatment with long-acting insulin analogues (insulin glargine and insulin detemir) compared to NPH insulin in patients with type 2 diabetes mellitus.

\section{METHODS}

\section{Criteria for considering studies for this review}

\section{Types of studies}

All randomised controlled trials with parallel or cross-over design, blinded or open-label with a duration of 24 weeks or longer. Reports of which no full publication exists were considered for inclusion in this review only, if the information available would allow for a publication in accordance with all criteria of the CONSORT statement.

\section{Types of participants}

People with type 2 diabetes mellitus.

\section{Types of interventions}

Comparison of long-acting insulin analogues (insulin glargine or insulin detemir) to NPH insulin. In case of a combination therapy (long-acting insulin analogue combined with another antihyperglycaemic drug) the additional antihyperglycaemic agent had to be part of each treatment arm. Only studies reporting on insulin scheme with subcutaneous application were considered for inclusion in this review.

\section{Types of outcome measures}

\section{Primary outcomes}

- number of overall, severe and nocturnal hypoglycaemia;

- glycaemic control as measured by glycosylated haemoglobin A1c (HbA1c).

\section{Secondary outcomes}

- mortality (total, diabetes specific and cardiovascular);

- cardiovascular morbidity (for example myocardial infarction, stroke, heart failure, revascularization procedures);

- diabetic late complications: renal failure, amputation, blindness or worsening of retinopathy;

- quality of life measured with a validated instrument;

- adverse events;

- costs.

\section{Covariates, effect modifiers and confounders}

Comparability of the antihyperglycaemic therapeutic scheme.

\section{Search methods for identification of studies}

\section{Electronic searches}

Published studies were identified through a literature search using

- The Cochrane Library (including the Cochrane Controlled

Trials Register (CENTRAL)),

- MEDLINE,

- EMBASE, and the CRD Databases (DARE, NHSEED, HTA) via Ovid Web Gateway.

For detailed search strategies please see under Appendix 1. 


\section{Searching other resources}

We also searched the reference lists of included trials and reviews. Handsearching was done by using cross-references from original articles and reviews.

Further

searches

for published or unpublished studies were carried out in registries of clinical trials at http://www.clinicalstudyresults.org and http:// www.clinicaltrials.gov.

We further on searched publicly accessible documents at the European Medicines Agency (EMEA) at http://www.emea.eu.int and the Food and Drug Administration (FDA) at http://www.fda.gov. Information on unpublished trials was sought from Sanofi-Aventis Pharmaceuticals (producer of insulin glargine) and Novo Nordisk (producer of insulin detemir)

\section{Data collection and analysis}

\section{Selection of studies}

Two authors independently screened the title and abstract of each reference identified by the search and applied the inclusion criteria. Interrater agreement was calculated using the kappa-statistic (Cohen 1960). Articles that appeared to fulfil the inclusion criteria were retrieved in full. In case of disagreement between the two authors, the full article was obtained and inspected independently by the two authors. Where differences in opinion existed, the differences were resolved by a third party. If a resolution of the disagreement was not possible, the article was added to those 'awaiting assessment' and the authors of the study were contacted for clarification.

\section{Data extraction and management}

Data from each included study were extracted by two independent authors using our data extraction form. Differences in data extraction were resolved by consensus, referring back to the original article. When necessary, information was sought from the authors of the primary studies. Our data extraction form was headed by the identification of the trial, the name of the first author, the year in which the trial was first published and the quality assessment criteria. The following data were extracted, checked and recorded: 1. General Information

The general information included the publication status (published or unpublished), if it was a duplicate publication, the sponsor of the trial (specified, known or unknown), the language of publication, the country of publication, the geographical area (urban or rural) and the setting where the trial was carried out (hospital inpatient, hospital outpatient, general practice).

2. Methods Section
The information about the methods summarised the characteristics of the trial, the characteristics of participants, the characteristics of interventions and the outcome measures used and reported in the publication.

2.1. Characteristics of the trial

The reported items included the design and duration of the trial, randomisation (and method), allocation concealment (and method), blinding (patients, people administering treatment, outcome assessors) and the check of blinding.

2.2. Characteristics of participants

Information about the participants included the number of participants in each group, how the participants were selected (random, convenience), the exclusion criteria used and the general characteristics (e.g. age, gender, nationality, ethnicity). Disease related information concerning duration of diabetes and late complications such as retinopathy, nephropathy, neuropathy and foot complications was extracted. The similarity of groups at baseline was checked as well as reports about withdrawals and losses to followup (reasons / description). If subgroup analysis was done, the reported reasons and the method were noted.

2.3. Characteristics of interventions

The relevant information to extract were the time of intervention, the length of follow-up (in months), the types of insulin (longacting analogues versus $\mathrm{NPH}$ ), the dose and route of administration and the administration schedule.

2.4. Characteristics of outcome measures

The measures mentioned in the outcome section and any other outcomes measured in the study were reported.

\section{Assessment of risk of bias in included studies}

Trials fulfilling the review inclusion criteria were assessed independently by two authors to evaluate methodological quality. Interrater agreement was calculated using the kappa-statistic (randomisation, allocation concealment, blinding). Again, any differences in opinion were resolved by discussion with a third author. Assessment for methodological quality was done using a modification of the criteria given in the Cochrane Handbook for Systematic Reviews of Interventions (Higgins 2005) and the criteria of Jadad and Schulz (Jadad 1996; Schulz 1995) and was made based on the following criteria:

(1) Minimisation of selection bias: - a) was the randomisation procedure adequate? - b) was the allocation concealment adequate? (2) Minimisation of performance bias: - a) were the patients and people administering the treatment blind to the intervention?

(3) Minimisation of attrition bias: - a) were withdrawals and dropouts completely described? - b) was analysis done by intention-totreat?

(4) Minimisation of detection bias: - a) were outcome assessors blind to the intervention?

Based on these criteria, studies were subdivided into the following three categories as set forth by the Cochrane Handbook for System- 
atic Reviews of Interventions (Higgins 2005):

A - all quality criteria met: low risk of bias.

$\mathrm{B}$ - one or more of the quality criteria only partly met: moderate risk of bias.

C - one or more criteria not met: high risk of bias.

For the purpose of the analysis in this review, trials were included if they meet the criteria A, B or C according to the Cochrane Handbook for Systematic Reviews of Interventions (Higgins 2005; Kunz 1998) (see also sensitivity analysis below). Also, individual quality criteria were investigated.

\section{Assessment of heterogeneity}

Heterogeneity between trials was assessed by the $\chi^{2}$-test. Quantification of heterogeneity was also examined with $\mathrm{I}^{2}$, ranging from $0 \%$ to $100 \%$ including its $95 \%$ confidence interval (Higgins 2002). $I^{2}$ demonstrates the percentage of total variation across studies due to heterogeneity and was used to judge the consistency of evidence. $\mathrm{I}^{2}$ values of $50 \%$ and more indicate a substantial level of heterogeneity (Higgins 2003).

\section{Data synthesis}

For the outcome percentage of glycosylated haemoglobin A1c (HbA1c), the change between baseline and endpoint was used for the comparison between the two groups. Weighted mean differences (WMD) were calculated using a random-effects model for the meta-analysis. In some studies the mean change and its variance for each group were presented in the published report of the trial. In other cases where these estimates were not reported, we had to calculate appropriate variances, if possible, from other statistics presented. We also took a second approach to assess the robustness of the results. We calculated a pooled estimate of the variance of change between baseline and endpoint from trials for which the correctly calculated values were reported.

Furthermore, we looked at patients with at least one episode of (severe, nocturnal, symptomatic and overall) hypoglycaemia. For the meta-analysis of severe hypoglycaemic episodes, the Peto-Odds Ratio was used, since the event rates were low. In all other cases a random-effects meta-analysis of the relative risk was performed.

\section{Subgroup analysis and investigation of heterogeneity}

We planned to perform subgroup analysis to explore the possible effect size differences for:

- different types of insulin analogues (glargine versus detemir).
- different additional anti hyperglycaemic therapy such as oral antidiabetic drugs versus insulin.

- NPH once daily versus NPH twice daily.

\section{Sensitivity analysis}

We planned to perform sensitivity analyses in order to explore the influence of the following factors on effect size:

- repeating the analysis excluding unpublished studies;

- repeating the analysis restricting for study quality;

- repeating the analysis excluding any very long or large studies to establish how much they dominate the results;

- repeating the analysis excluding studies using the following filters: language of publication, source of funding (industry versus other).

The robustness of the results was also planned to be tested by repeating the analysis using different measures of effect size (risk difference, odds ratio etc.) and different statistical models (fixed and random-effects models).

\section{RES U L T S}

\section{Description of studies}

See: Characteristics of included studies; Characteristics of excluded studies; Characteristics of studies awaiting classification.

\section{Results of the search}

The search in the electronic databases yielded 2065 records, of which 818 could be excluded as duplicates. Of the remaining 1247 publications, 1228 were excluded by consensus as not relevant to the question under study on the basis of their abstracts and 19 were identified for further examination. One additional publication of potential relevance, not listed in the electronic databases, was identified through communication with insulin producing companies (Kawamori 2003). No studies were identified through inquiries addressed to experts in the field, EMEA, FDA and registries of clinical trials. After screening the full text of the selected publications, 11 publications on nine studies finally met the inclusion criteria (see Figure 1 for details of the QUOROM (quality of reporting of meta-analyses) statement)).

All relevant studies were published after the year 2000 and written in English. 
Figure I. QUOROM (quality of reporting of meta-analyses) flow-chart of study selection

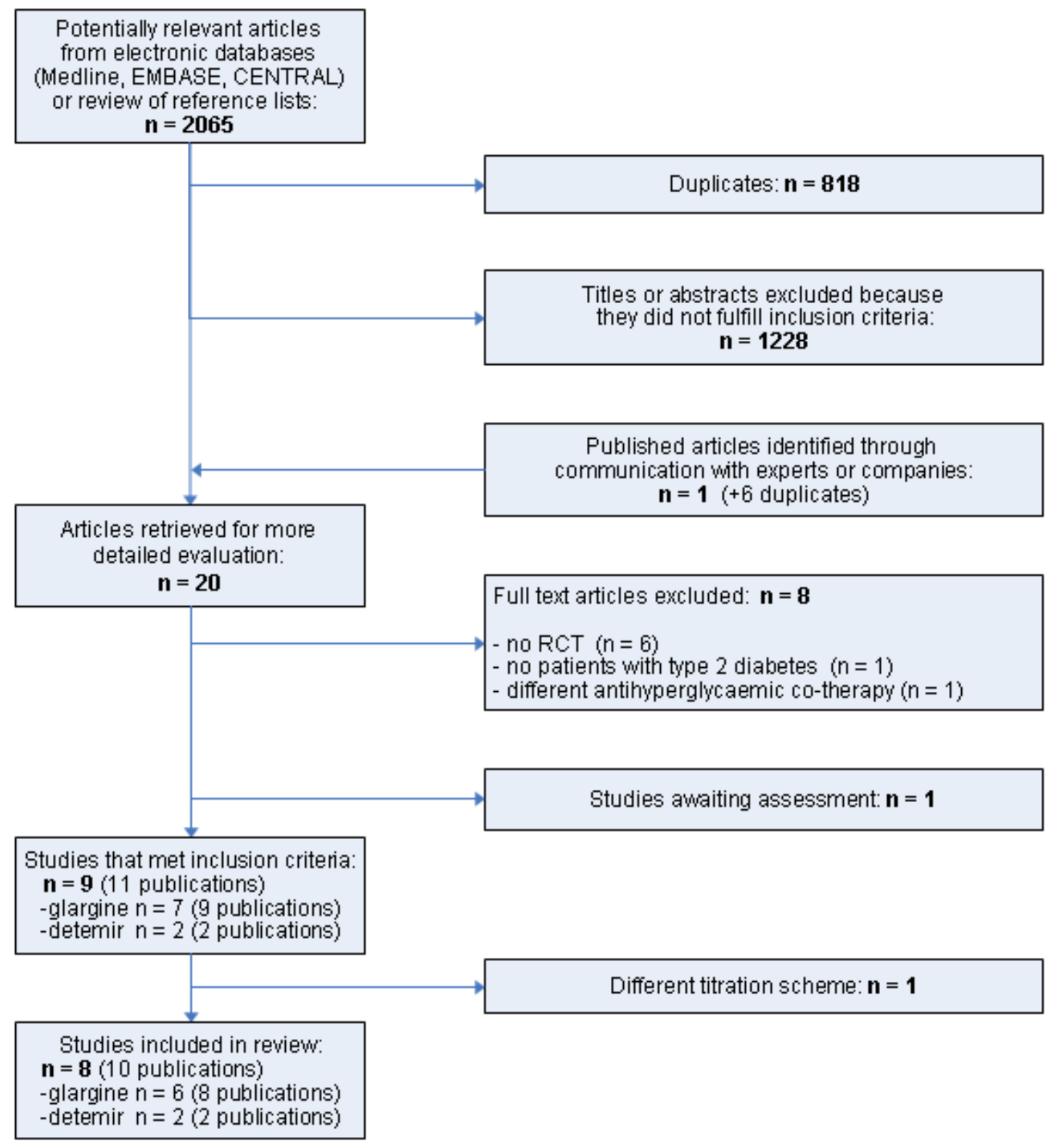




\section{Assessment of publication bias interrater agreement}

Interrater agreement for study selection, that is qualifying a study as "included" or "potentially relevant" was $99 \%$.

\section{Studies awaiting assessment}

Through communication with Sanofi-Aventis we became aware of one additional study comparing insulin glargine with NPH insulin in patients with type 2 diabetes mellitus (Kawamori 2003), which was not listed in any of the electronic databases searched. Unfortunately, the publication was not available in time for inclusion in this review. We therefore will assess its relevance in the next update of this review.

\section{Included studies}

\section{Interventions}

\section{Comparisons}

Of the nine included studies seven investigated the comparable effects of insulin glargine (Eliaschewitz 2006; Fritsche 2003; Massi 2003; Rosenstock 2001; Riddle 2003; Yki-Järvinen 2006; Yokoyama 2006) and NPH insulin and two studies insulin detemir (Haak 2005; Hermansen 2006) versus NPH insulin, either in combination with oral antidiabetic drugs (OADs) (Eliaschewitz 2006; Fritsche 2003; Hermansen 2006; Massi 2003; Riddle 2003; Yki-Järvinen 2006) or a short-acting insulin (Haak 2005; Rosenstock 2001) or both (Yokoyama 2006).

The design of the investigation by Yokoyama 2006 required an upward titration of insulin glargine with a target of a fraction of $50 \%$ of the basal insulin on the total daily insulin requirement. In contrast to this, the fraction of NPH on the total daily insulin requirement was left unchanged, thus introducing a difference in the treatments of the two comparison groups, making the study unfit to answer the question of substance specific differences of insulin glargine and NPH insulin. Even though this was the case, we were not able to exclude this study formally on the basis of the prespecified exclusion criteria. We therefore present this investigation in the table Characteristics of included studies and in Table 1, Appendix 2, Appendix 3, Appendix 4, Appendix 5 and Appendix 6; but did not consider it for the meta-analyses, nor discuss it any further.

\section{Glargine versus $\mathrm{NPH}$}

One study (Fritsche 2003) compared two interventional arms with different insulin schedules, glargine in the morning and at bedtime, versus NPH at bedtime. In all the other studies insulin glargine was injected at bedtime. NPH was given once daily at bedtime in all investigations with the exception of one study (Rosenstock 2001) in which NPH could be applied at bedtime or twice daily (at bedtime and in the morning):

- Fritsche 2003 glargine at morning plus $3 \mathrm{mg}$ glimepiride versus NPH at bedtime plus $3 \mathrm{mg}$ glimepiride;

- Fritsche 2003 glargine at bedtime plus $3 \mathrm{mg}$ glimepiride versus NPH at bedtime plus $3 \mathrm{mg}$ glimepiride;

- Massi 2003 glargine at bedtime plus sulphonylurea (SU) alone or in combination with metformin, acarbose or metformin alone versus NPH at bedtime plus SU alone or in combination with metformin, acarbose or metformin alone;

- Riddle 2003 glargine at bedtime plus SU, metformin or pioglitazone or rosiglitazone versus NPH at bedtime plus SU, metformin or pioglitazone or rosiglitazone;

- Yki-Järvinen 2006 glargine at bedtime plus metformin versus NPH at bedtime plus metformin;

- Eliaschewitz 2006 glargine at bedtime plus $4 \mathrm{mg}$ glimepiride in the morning versus NPH at bedtime plus $4 \mathrm{mg}$ glimepiride in the morning;

- Rosenstock 2001 glargine at bedtime plus premeal regular insulin versus NPH at bedtime or at bedtime and in the morning plus premeal regular insulin.

Two additional publications were identified which reported on the results for different subgroups of the studies by Massi 2003 and Rosenstock 2001. In the publication by Yki-Järvinen 2000 the results on the subgroup of insulin-naive patients from the study by Massi 2003 are presented. Fonseca 2004 describes the findings on the subgroup of patients applying insulin only once daily from the investigation by Rosenstock 2001 .

\section{Detemir versus $\mathrm{NPH}$}

In both included studies (Haak 2005; Hermansen 2006) insulin detemir as well as NPH insulin was applied once or twice daily, either in combination with oral antidiabetic drugs (OADs) (Hermansen 2006) or with premeal insulin aspart (Haak 2005):

- Haak 2005 detemir once daily at bedtime or twice daily at bedtime and in the morning plus premeal insulin aspart versus $\mathrm{NPH}$ once daily at bedtime or twice daily at bedtime and in the morning plus premeal insulin aspart

- Hermansen 2006 detemir twice daily plus metformin, insulin secretagogues or alpha-glucosidase inhibitors versus NPH

Long-acting insulin analogues versus NPH insulin (human isophane insulin) for type 2 diabetes mellitus (Review) 
twice daily plus metformin, insulin secretagogues or alphaglucosidase inhibitors

\section{Number of study centres}

All included trials had a multi-centre design ranging from 7 to 111 centres. Seven studies involved more than 50 centres (Eliaschewitz 2006; Fritsche 2003; Haak 2005; Hermansen 2006; Massi 2003; Riddle 2003; Rosenstock 2001).

\section{Country and location}

Four studies were performed in Europe (Fritsche 2003; Haak 2005; Hermansen 2006; Yki-Järvinen 2006), two in North America (Riddle 2003; Rosenstock 2001), one in Europe, one in South Africa (Massi 2003) and one Latin America (Eliaschewitz 2006).

\section{Setting}

None of the publications presented details about the setting.

\section{Treatment before study}

Pre-study treatment consisted of OADs in five investigations (Eliaschewitz 2006; Fritsche 2003; Hermansen 2006; Riddle 2003; Yki-Järvinen 2006), mostly sulfonylureas, metformin and acarbose. Additionally, glitazones and insulin secretagogues were each allowed in one study. In another study patients could be treated with OADs or insulin (Massi 2003) and had to be treated with insulin in two further studies (Haak 2005; Rosenstock 2001).

\section{Methods}

\section{Duration of intervention and duration of follow-up}

Most studies had a treatment duration of approximately six months. One trial (Massi 2003) lasted for 12 months and one (Yki-Järvinen 2006) for nine months.

Treatment duration and duration of follow-up were identical in all trials.

\section{Run-in period}

Only one study had a formal run-in period (Riddle 2003). All other studies, with the exception of one (Hermansen 2006) reported on a screening period of four weeks duration in most cases and 1 to 4 weeks in one study (Rosenstock 2001) and three weeks in another study (Haak 2005): During this phase, in two investigations ( Eliaschewitz 2006; Fritsche 2003) the treatment was changed from previous oral antihyperglycaemic therapy to glimepiride. In the publication by Haak 2005 no information was given on possible changes in treatment. In the rest of the studies patients continued their ongoing antihyperglycaemic treatment during this screening phase.

\section{Language of publication}

All included publications were published in English.

\section{Participants}

\section{Who participated}

Only patients with diabetes mellitus type 2 were included in the studies. Mean duration of diabetes ranged from 8 to 14 years. Participants were mostly of Caucasian origin (for those publications with no information on the ethnic composition of the study population, it can be inferred from the study locations) with mean age ranging from 55 to 62 years. Most patients were overweight, with a body mass index (BMI) ranging from 27 to $33 \mathrm{~kg} / \mathrm{m}^{2}$. None of the studies was performed with pharmaco-naive (that is, people treated with diet or exercise or both only) patients. Metabolic control in patients randomised to insulin glargine or detemir ranged from $7.9 \%$ to $9.5 \%$ glycosylated haemoglobin A1c (HbAlc) at baseline.

Only one study (Rosenstock 2001) showed a possible clinically important difference in baseline characteristics. In this investigation more patients in the NPH group had retinopathy at the beginning of the trial than in the insulin glargine group (for details see table Characteristics of included studies).

\section{Inclusion criteria}

Various inclusion criteria, such as certain HbA1c levels, age and BMI ranges and pre-study treatment requirements, were specified by the investigators. Three studies (Eliaschewitz 2006; Fritsche 2003; Hermansen 2006) explicitly chose participants who were poorly controlled on oral antihypertensive therapy (for details see table Characteristics of included studies).

\section{Exclusion criteria}

Investigators specified various exclusion criteria. In two studies (Haak 2005; Hermansen 2006) patients with proliferative retinopathy or maculopathy requiring treatment and in one (Massi 2003) patients with retinopathy who have received surgical treatment or would require surgical treatment within three months were excluded. In two publications (Haak 2005; Hermansen 2006) a history of recurrent major hypoglycaemia and hypoglycaemia unawareness (Hermansen 2006; Riddle 2003) were listed among exclusion criteria (for details see table Characteristics of excluded studies). 


\section{Diagnostic criteria}

None of the included studies explicitly reported diagnostic criteria.

\section{Outcomes}

\section{Primary outcomes}

Seven studies investigated $\mathrm{HbA1c}$, either at endpoint or change from baseline to endpoint and one (Riddle 2003) the percentage of patients achieving HbA1c equal to or less than $7.0 \%$ without symptomatic nocturnal hypoglycaemia as primary outcome. Fritsche 2003 also lists the frequency of patients experiencing hypoglycaemia as a primary outcome.

\section{Secondary and additional outcomes}

Most studies evaluated the frequency of overall or symptomatic, severe and nocturnal hypoglycaemia, fasting plasma glucose (FPG), blood glucose (BG) profiles, insulin doses, body weight and adverse events as further outcomes (for details see table Characteristics of included studies). Two investigations ( Eliaschewitz 2006; Fritsche 2003) compared the percentage of patients achieving a HbA1c equal to or less than $7.5 \%$ and one (Hermansen 2006) the percentage of patients achieving a HbAlc equal to or less than $7.0 \%$ without hypoglycaemia as a secondary outcome (for details see table Characteristics of included studies).

\section{Hypoglycaemia}

All studies investigating insulin glargine versus NPH insulin reported data on severe, symptomatic and nocturnal hypoglycaemic events. From the two trials comparing insulin detemir with NPH insulin results for severe, overall and nocturnal hypoglycaemic events were available.

In all included studies neither the participants nor the caregivers were blinded. Therefore, the reliability of the results revealed is heavily dependent on how much room the definition of hypoglycaemic events in the studies leaves for subjective interpretation or deliberate or non-deliberate exertion of influence. Since symptoms without blood glucose measurements were sufficient for counting an event as hypoglycaemia in all studies, it is not possible to exclude bias for any reported results on hypoglycaemia. This is also true for severe hypoglycaemic events because the criterion of "requirement of assistance from another person" alone is also susceptible to bias.

The definition of hypoglycaemic events as given in the methods sections or as reported in the different publications are listed in Table 1 alongside with our appraisal of possible bias.

None of the studies reported on blinded outcome assessment, which would be one method for minimisation of possible detection bias.

\section{Excluded studies}

Eight studies were excluded upon further scrutiny. Reasons for exclusion were: not a randomised controlled trial, not a comparable co-intervention and no individuals with type 2 diabetes mellitus included (see Characteristics of excluded studies).

\section{Risk of bias in included studies}

For details on methodological quality of included studies see Appendix 6.

All included studies were parallel trials. No cross-over studies or trials with factorial design fulfilling the inclusion criteria were identified by the search. Two studies (Riddle 2003; Yki-Järvinen 2006) had a superiority design, one (Eliaschewitz 2006) an equivalence and two (Haak 2005; Hermansen 2006) a non-inferiority design. In the equivalence and non-inferiority trials equivalence intervals ranging from $0.4 \%$ (Haak 2005; Hermansen 2006) to $0.5 \%$ (Eliaschewitz 2006) HbAlc were specified. For three studies (Fritsche 2003; Massi 2003; Rosenstock 2001) the hypothesis remained unclear.

Interrater agreement for the key quality indicators randomisation, concealment of allocation and blinding was $100 \%$.

All included studies were rated as being of insufficient methodological quality ("C"). Mostly, this was due to the poor quality of key methodological elements or poor reporting on them.

\section{Allocation}

All included studies were randomised controlled trials and randomised individuals. Reporting on methods of randomisation was poor in most of the trials. The method of randomisation was adequate in one study Haak 2005 and specified somewhat in three (Fritsche 2003; Massi 2003; Riddle 2003) and described in more detail in one publication (Yki-Järvinen 2006).

The method of concealment of allocation was adequate in five studies (Haak 2005; Hermansen 2006; Massi 2003; Riddle 2003; Rosenstock 2001) and unclear in the other three. For one study (Haak 2005) information on both items was available through personal communication.

\section{Blinding}

Participants or caregivers were not blinded to the treatment in any of the studies. None of the publications contained information on possible blinded outcome assessment. Even if blinding seems to be hard in such trials because insulines glargine and detemir are clear solutions while NPH insulin is of milky appearance, the fact remains that an open design, especially with no blinded outcome assessment and poor or unclear concealment of allocation, carries an increased risk for bias. 


\section{Incomplete outcome data}

\section{Intention-to-treat, per-protocol analyses and missing data}

In all investigations main analyses used an intention-to-treat approach, which was clearly defined in six publications. Even though none of the studies included all randomised patients in the analyses (so that they are not, in a strict sense, intention to treat analyses) the difference between randomised and analysed patients was so small in four studies (Fritsche 2003; Riddle 2003; Hermansen 2006; Yki-Järvinen 2006) that no substantial problems should arise from this fact. For one study (Haak 2005) the difference between the number of randomised and analysed patients was considerable. In three publications (Massi 2003; Rosenstock 2001; Eliaschewitz 2006) the number of analysed patients was not reported.

A per-protocol analysis was reported for one study with an equivalence (Eliaschewitz 2006) design and one with a non-inferiority design (Hermansen 2006), but not for the second investigation with a non-inferiority analysis (Haak 2005).

For analyses in four studies (Eliaschewitz 2006; Hermansen 2006; Riddle 2003; Rosenstock 2001) last observation carried forward (LOCF) was used for missing data. LOCF was defined in only four of these publications (Eliaschewitz 2006; Hermansen 2006; Riddle 2003; Rosenstock 2001). For the four investigations it remained unclear how missing data were considered for the analyses.

\section{Screened and randomised patients}

The number of screened patients was available for all studies. Altogether, in the studies included in this review, approximately 1715 patients were randomised to insulin glargine and 578 patients to insulin detemir. The largest study investigating insulin glargine included a total of 764 patients, the smallest 110 patients. The studies on insulin detemir included a total of 505 and 476 patients.

\section{Discontinuing participation and attrition rates}

All studies on insulin glargine described discontinuing patients and provided at least some details on the reasons for terminating the trial. Discontinuation rates in the glargine arms varied from $1.6 \%$ to $10.2 \%$. The rate of patients discontinuing participation was dissimilar between the treatment arms in three (Eliaschewitz 2006; Fritsche 2003; Rosenstock 2001) of these studies. In all of these cases the rate was lower in the NPH arm.

One study reporting on insulin detemir (Haak 2005) showed a higher rate of discontinuation in the insulin detemir group, while in the second study the discontinuation rate was $4.2 \%$ in the detemir arm and similar (though slightly higher) for patients treated with NPH insulin.

\section{Other potential sources of bias}

\section{Definition of primary and secondary endpoints}

Primary endpoints were clearly defined in all the studies. In one publication (Fritsche 2003) two primary endpoints were described.

The number of further endpoints reported varied between four and 11; additional endpoints not described in the methods or statistics section of the papers were presented in most publications. Adjustment for multiple testing was described in one study (YkiJärvinen 2006), not done in five (Fritsche 2003; Haak 2005; Hermansen 2006; Riddle 2003; Rosenstock 2001) and unclear in two (Massi 2003; Eliaschewitz 2006).

\section{Power calculation}

For all studies details of power calculation were reported. The numbers of participants required ranged from 110 to 375 and were not known for one publication (Rosenstock 2001).

\section{Compliance measures}

None of the publications reported compliance measures, but some reported that participants were withdrawn because of lack of compliance.

\section{Funding}

Five publications reported commercial funding, three (Haak 2005; Hermansen 2006; Rosenstock 2001) did not indicate funding sources.

\section{Publication status}

All studies were published in peer review journals. None was circulated as a journal supplement.

\section{Effects of interventions}

Because it is not possible to include a comparison group twice in the same meta-analysis we could not consider all treatment arms from the Fritsche study (Fritsche 2003) for the meta-analyses. For reasons of homogeneity, only the comparison of glargine in the evening versus NPH in the evening was included in our analyses.

\section{Glycosylated haemoglobin A Ic (HbAlc)}

HbA1c values were available in all studies for verification of metabolic control. For the meta-analysis the difference in change of HbA1c from baseline to study endpoint was chosen as the outcome of interest. 


\section{Glargine versus NPH}

In two studies (Eliaschewitz 2006; Fritsche 2003) with three comparisons, the change in $\mathrm{HbAlc}$ from baseline to endpoint and measures of variance for each treatment arm were reported. One study (Rosenstock 2001) presented adjusted values for the HbA1c change and measures of variance. In two publications (Massi 2003; Riddle 2003) the changes of HbA1c but no measures of variances were reported. For one investigation (Yki-Järvinen 2006) the change in $\mathrm{HbA1c}$ was calculated from the given figures for $\mathrm{HbA1c}$ at baseline and endpoint; values for SD were also calculated for this study.

Meta-analyses were performed:

(1) including only studies for which relevant data were either available or could be calculated based on information in the study report (Eliaschewitz 2006; Fritsche 2003; Rosenstock 2001; Yki-Järvinen 2006). The weighted mean difference of change of $\mathrm{HbA1c}$ from baseline to study endpoint was estimated to be $0.1 \%$ (95\% confidence interval $(\mathrm{CI})-0.1$ to $0.2 ; \mathrm{P}=0.49$ ) in favour of $\mathrm{NPH}$. The test of heterogeneity yielded a $\mathrm{P}$ value of $0.41\left(\mathrm{I}^{2}=\right.$ $0 \%)$.

(2) including all studies (Eliaschewitz 2006; Fritsche 2003; Massi 2003; Riddle 2003; Rosenstock 2001; Yki-Järvinen 2006) using pooled values for SD, for further confirmation of the above result: The weighted mean difference of change of HbA1c from baseline to study endpoint was estimated to be $0.00 \%$ (95\% CI -0.1 to $0.1 ; \mathrm{P}=0.93$ ). The test of heterogeneity gave a P-value of 0.43 (I $2=0 \%)$.

The second comparison of the Fritsche study (Fritsche 2003) showed that reduction of $\mathrm{HbA1c}$ from baseline to end of study was significantly greater in patients administering insulin glargine in the morning versus patients injecting NPH insulin in the evening. For the subgroup of insulin-naive patients in the study by Massi 2003, no statistically significant differences were found for the change of HbA1c or HbA1c at endpoint (Massi 2003). Also, the differences in HbAlc at endpoint and in the change of HbA1c were not statistically significant different for the subgroup of patients applying insulin NPH only once daily in the investigation by Rosenstock 2001 (Rosenstock 2001).

\section{Detemir versus NPH}

For one study (Haak 2005) the changes of HbA1c from baseline to endpoint were reported without measures of variances. Values for HbAlc at baseline and endpoint are presented in the other investigation (Hermansen 2006).

Meta-analyses performed:

(1) Change of $\mathrm{HbA1c}$ from baseline to endpoint, SDs were calculated for both studies:

The weighted mean difference of change of HbA1c from baseline to study endpoint was estimated to be $0.1 \%$ (95\% CI 0.01 to 0.2 ; $\mathrm{P}=0.03)$ in favour of NPH insulin. The test of heterogeneity gave a $\mathrm{P}$ value of $0.46\left(\mathrm{I}^{2}=0 \%\right)$. Even though this result indicates a statistically significant difference in change of HbAlc between insulin detemir and NPH insulin, the difference is well inside the non-inferiority margin of $0.4 \% \mathrm{HbA} 1 \mathrm{c}$ which both of the studies specified.

(2) Change of HbAlc from baseline to endpoint, pooled SDs were used for both studies.

The weighted mean difference of change of HbA1c from baseline to study endpoint was estimated to be $0.2 \%$ ( $95 \%$ CI -0.02 to $0.3 ; \mathrm{P}=0.08)$ in favour of $\mathrm{NPH}$ insulin. The test of heterogeneity gave a $\mathrm{P}$ value of $0.56\left(\mathrm{I}^{2}=0 \%\right)$.

\section{Hypoglycaemia}

Information on hypoglycaemia was available from all included studies. Reporting on hypoglycaemic events differed in various aspects: While most studies presented the number of patients or percentage of patients with hypoglycaemic episodes, only a few reported frequency of hypoglycaemia as events / patient / time or as the number of events. Also, the definition of hypoglycaemia was different between studies. For detailed information on the various definitions of symptomatic, overall, severe and nocturnal hypoglycaemic episodes see Table 1 . Duration of follow-up was approximately six months in the majority of the studies and nine months (Yki-Järvinen 2006) in one study and 12 months (Massi 2003) in another. Since the chance of patients experiencing a hypoglycaemic event rises with duration of follow-up, and because it was not possible to calculate the frequency of hypoglycaemia as events / patient / time for most of the studies, it was judged not to be appropriate to include the investigations with follow-up periods of 9 and 12 months (Yki-Järvinen 2006; Massi 2003) in the meta-analyses.

\section{Severe hypoglycaemia}

For details see Appendix 4.

\section{Glargine versus NPH}

Information on severe hypoglycaemia was available from all included studies expressed as the number of patients with severe hypoglycaemic episodes. Uniformly in all investigations only a few such episodes occurred. Because of the small number of affected patients in the meta-analysis the Peto-Odds Ratio was calculated. The Peto-OR was estimated to be 0.70 (95\% CI 0.40 to 1.23 ) in favour of insulin glargine. The test of heterogeneity gave a $P$ value of $0.26\left(I^{2}=26 \%\right)$.

\section{Results from studies not included in the meta-analysis:}

For the second comparison of the Fritsche study (Fritsche 2003) the incidence of severe hypoglycaemic events was comparable for 
patients applying insulin glargine in the morning and those injecting NPH insulin in the evening. In one of the longer studies (Yki-Järvinen 2006) no episodes of severe hypoglycaemia were detected during nine months of follow-up. The 12 months, study (Massi 2003) reported severe hypoglycaemia for $1.7 \%$ of patients treated with insulin glargine and $1.1 \%$ of patients treated with $\mathrm{NPH}$ insulin. No information on the statistical significance of this difference is presented.

\section{Detemir versus NPH}

Information on severe hypoglycaemia was available from reported data for one study (Hermansen 2006) and from data acquired through personal communication for the other study (Haak 2005). The Peto-OR for severe hypoglycaemia was estimated to be 0.50 (95\% CI 0.18 to $1.38 ; \mathrm{P}=0.18$ ) under therapy with insulin detemir compared to NPH treatment. The test of heterogeneity gave a $\mathrm{P}$ value of $0.2\left(\mathrm{I}^{2}=44 \%\right)$.

\section{Symptomatic and overall hypoglycaemia}

For details see Appendix 4.

\section{Glargine versus NPH}

Three studies (Eliaschewitz 2006; Fritsche 2003; Rosenstock 2001) reported frequency of symptomatic hypoglycaemia as the number or the percentage of patients with events, and could be included in the meta-analysis. The relative risk was 0.84 (95\% CI 0.75 to $0.95 ; \mathrm{P}=0.005)$ in favour of treatment with insulin glargine. The test of heterogeneity gave a $\mathrm{P}$ value of $0.17\left(\mathrm{I}^{2}=\right.$ $44 \%)$.

\section{Results from studies not included in the meta-analysis:}

In the second comparison of the Fritsche study (Fritsche 2003), between patients applying insulin glargine in the morning and those injecting NPH insulin in the evening, no statistically significant difference in the percentage of patients experiencing symptomatic hypoglycaemic events was found.

One study, reporting event rates only (Riddle 2003), also found a statistically significant difference in the event rates in favour of insulin glargine. Event rates were 14 events / patient / year in the glargine group and 18 events / patient / year in the NPH group, $\mathrm{P}<0.02$.

Of the two longer studies, one (Yki-Järvinen 2006) found an event rate of 5.4 events / patient / year for therapy with insulin glargine and of 8 events / patient / year for NPH therapy, with a P value for the difference of event rates of 0.12 . The other of the longer studies (Massi 2003) reported 35\% of patients in the glargine group and $41 \%$ of patients in the NPH group affected by symptomatic hypoglycaemic events. The difference was described as statistically not significant.

Results for overall hypoglycaemia were reported only for one study (Fritsche 2003) and thus no meta-analysis was conducted for this outcome. In the study by Fritsche 2003, 74\% of patients treated with insulin glargine in the morning, $68 \%$ of patients treated with insulin glargine in the evening and $75 \%$ of patients treated with $\mathrm{NPH}$ insulin at bedtime experienced at least one episode of hypoglycaemia. Neither of the differences was statistically different. For the subgroup of insulin-naive patients in the study by Massi 2003, Yki-Järvinen reports in her 2001 publication that 33\% of patients treated with insulin glargine and $43 \%$ of NPH treated patients experienced at least one episode of symptomatic hypoglycaemia. The difference in frequency of hypoglycaemia between the two treatment groups was statistically significant $(P=0.04)$. Also, in the subgroup of patients applying insulin only once daily in the study by Rosenstock 2001, reported in the paper by Fonseca 2004, fewer patients in the glargine group (15\%) experienced symptomatic hypoglycaemia than in the NPH group (27\%).

\section{Detemir versus NPH}

Symptomatic hypoglycaemia was reported only in one study ( Hermansen 2006). Reported event rates were 4.9 events / patient / year in the detemir group and 9.7 events / patient / year in the NPH group. The difference was statistically significant: $\mathrm{P}<0.001$, RR 0.56 (95\% CI 0.42 to 0.74$)$.

Information on overall hypoglycaemia was available from both included studies. The meta-analysis yielded a relative risk of 0.82 (95\% CI 0.74 to $0.90 ; \mathrm{P}<0.0001)$ for treatment with insulin detemir versus NPH insulin. No statistically significant heterogeneity was detected, $\mathrm{P}$ value $0.4\left(\mathrm{I}^{2}=0 \%\right)$.

\section{Symptomatic nocturnal hypoglycaemia}

For details see Appendix 4.

\section{Glargine versus NPH}

Three studies (Eliaschewitz 2006; Fritsche 2003; Rosenstock 2001) reported frequency of nocturnal hypoglycaemia as the number or the percentage of patients with events, and could be included in the meta-analysis. The relative risk was 0.66 (95\% CI 0.55 to $0.80 ; \mathrm{P}<0.0001)$ in favour of treatment with insulin glargine. The test of heterogeneity gave a $\mathrm{P}$ value of $0.23\left(\mathrm{I}^{2}=33 \%\right)$.

\section{Results from studies not included in the meta-analysis:}

The number of patients experiencing nocturnal hypoglycaemic events was statistically significantly lower for patients treated with insulin glargine in the morning compared to patients treated with NPH insulin in the evening in the Fritsche study (Fritsche 2003). 
The other study reporting event rates only (Riddle 2003) also found a statistically significant difference in the event rates in favour of insulin glargine. Event rates were four events / patient / year in the glargine group and seven events / patient / year in the $\mathrm{NPH}$ group.

Of the two longer studies, one (Yki-Järvinen 2006) did not report on nocturnal hypoglycaemia. The other of the longer studies (Massi 2003) reported 12\% of patients in the glargine group and $24 \%$ of patients in the NPH group affected by nocturnal hypoglycaemic events. The difference was statistically significant, $P$ value 0.0002 .

For the subgroup of insulin-naive patients in the study by Massi 2003, Yki-Järvinen reports in her paper from 2001 that $10 \%$ of patients treated with insulin glargine and $24 \%$ of NPH treated patients experienced at least one episode of nocturnal hypoglycaemia. The difference in frequency of hypoglycaemia between the two treatment groups was statistically significant, P value 0.0001 . In a second study (Rosenstock 2001), for the subgroup of patients applying NPH insulin once daily a reduction of the proportion of patients experiencing nocturnal hypoglycaemia was found for treatment with insulin glargine (15\%) compared to NPH therapy (27\%) (Fonseca 2004).

\section{Detemir versus NPH}

Combined results from the two studies showed a relative risk of 0.63 (95\% CI 0.52 to 0.76 ; $\mathrm{P}<0.00001$ ) for patients experiencing at least one nocturnal hypoglycaemic event in favour of insulin detemir compared to NPH insulin. The test of heterogeneity gave a $\mathrm{P}$ value of $0.88\left(\mathrm{I}^{2}=0 \%\right)$.

\section{Mortality}

No study was designed or adequately powered to investigate mortality.

\section{Glargine versus NPH}

The number of patients who died during follow-up was reported in three studies (Eliaschewitz 2006; Fritsche 2003; Massi 2003). Numbers of events were very small in all cases. Formal statistical tests were not reported. For details see Appendix 5.

\section{Detemir versus NPH}

Data on mortality were available from one study (Haak 2005). In this study one patient in the insulin detemir treatment group and no patients in the NPH insulin therapy group died.

\section{Cardiovascular morbidity}

Not a single trial reported on cardiovascular morbidity, but from personal communication data for one study (Haak 2005) investigating the effects of insulin detemir versus NPH insulin became available. Only a very small number of events occurred during this trial. Due to this fact no inferences on possible different effects on cardiovascular morbidity can be drawn from this study. For a detailed listing see Appendix 5.

\section{Diabetic late complications}

There were no reports on diabetic late complications in any of the trials. For two studies (Massi 2003; Rosenstock 2001) some results on retinopathy could be found in the FDA reports. In one of these investigations (Massi 2003) 8.4\% of patients in the glargine group and $14 \%$ of patients in the NPH group who had no retinopathy at baseline developed non-proliferative retinopathy during the study, and $1.8 \%$ versus $2.4 \%$ in the respective treatment groups developed clinically significant macula oedema. Progression of retinopathy by more than three stages was seen in $5.9 \%$ versus $9.1 \%$ of patients. Development of clinically significant macula oedema was found to be statistically not significantly more frequent in patients treated with insulin glargine with $11.2 \%$ of patients affected in the glargine group and $6.5 \%$ of patients in the NPH group, $\mathrm{P}=$ 0.1 . For this outcome there was a marked difference between patients without pre-treatment with insulin and insulin pre-treated patients. While in the former group glargine therapy resulted in a higher rate of macula oedema with $14 \%$ affected versus $4 \%$ in the NPH group, the opposite was found in the subgroup of patients already treated with insulin before the study: $1.9 \%$ versus $12.7 \%$. Results in the second study (Rosenstock 2001), according to the FDA report, showed a statistically significant higher rate of progression of retinopathy by three or more stages in patients treated with glargine $(7.5 \%)$ than in patients treated with $\mathrm{NPH}$ insulin (2.7\%); $\mathrm{P}=0.028$.

For one study comparing insulin detemir with NPH insulin ( Haak 2005), results on diabetic late complications were available through personal communication with the author. But because of the short duration of the trial only a very few events occurred, making it impossible to draw any conclusions from results of this study. A detailed listing of events is presented in Appendix 5.

\section{Quality of life}

No trial reported results on quality of life. Only one trial (Eliaschewitz 2006) reported results on treatment satisfaction with the Diabetes Treatment and Satisfaction Questionnaire (DTSQc). In this investigation a statistically significant more pronounced improvement of mean scores of treatment satisfaction was reported for treatment with insulin glargine versus NPH insulin. While the DTSQc version measures change, the publication reports baseline and end of study values for the status version of the DTSQ only. 


\section{Adverse events}

For details see Appendix 3.

Some information on adverse events could be derived from all studies, even though reporting on adverse events was limited.

Due to the differences in duration of follow-up and reporting of adverse events or lack of data, a meta-analysis was not performed.

\section{Glargine versus NPH}

Four studies (Eliaschewitz 2006; Fritsche 2003; Massi 2003; YkiJärvinen 2006) presented data concerning the overall number of patients with events or the number of events. In all these studies numbers for adverse events were comparable for all treatment arms. Formal statistical testing was not reported in any of the studies. Results for serious adverse events were reported only in two studies (Eliaschewitz 2006; Yki-Järvinen 2006) and adverse events possibly related to study medication in four (Eliaschewitz 2006; Massi 2003; Rosenstock 2001; Yki-Järvinen 2006). No important differences were found for these events.

The number of patients withdrawing due to adverse events was reported in another six studies (Eliaschewitz 2006; Fritsche 2003; Massi 2003; Riddle 2003; Rosenstock 2001; Yki-Järvinen 2006). Again the numbers were comparable between treatment groups.

\section{Detemir versus NPH}

For both studies (Haak 2005; Hermansen 2006) the authors stated in their publications that no difference in frequency of adverse events was found between the treatment groups, but no numbers or formal statistics were reported.

In one study (Haak 2005) the percentage of patients with treatment related events was comparable for both treatments while the percentage of patients experiencing serious adverse events was smaller under treatment with insulin detemir. The number of patients who withdrew from the study because of adverse events was higher in the insulin detemir group. Numbers of affected patients in the two latter comparisons are very small. No formal statistical tests were presented. Also, in the second study (Hermansen 2006) the authors state that no difference in frequency of adverse events or the number of patients who withdrew because of adverse events was found between the treatment groups, but no numbers or formal statistics were reported.

Both studies (Haak 2005; Hermansen 2006) found that patients under treatment with insulin detemir gained statistically significant less weight than patients with NPH therapy. The difference was $-0.8 \mathrm{~kg}$ in one (Haak 2005) and $-1.6 \mathrm{~kg}$ in the other (Hermansen 2006) trial.

\section{Costs}

No study reported data on costs of treatment with long-acting insulin analogues compared to NPH insulin therapy.

\section{Heterogeneity}

In all studies except one (Riddle 2003) the number of patients experiencing severe hypoglycaemic events was lower in the insulin glargine group. Since differences in the design of the trials or the definition of severe hypoglycaemia are not a likely explanation and because numbers of affected patients were very small, a chance result seems to be the most plausible cause for the different results. Heterogeneity of results was also found for the frequency of severe hypoglycaemic events in the trials comparing insulin detemir and $\mathrm{NPH}$ insulin. While the difference in co-medication pre-meal insulin aspart (Haak 2005) or OADs (Hermansen 2006) could be a possible explanation for this finding, it seems more likely to be caused by a chance result due to the very small numbers of affected patients.

Heterogeneity was also found for the magnitude of the reduction of symptomatic hypoglycaemia. Compared to insulin glargine in the evening in combination with a sulfonylureas in the morning (Eliaschewitz 2006; Fritsche B 2003), the treatment with glargine combined with premeal short-acting insulin (Rosenstock 2001) resulted in a lower reduction of symptomatic hypoglycaemia. This difference is likely due to the additional premeal insulin leading to a higher chance for hypoglycaemia.

Heterogeneity was also detected in the results concerning the differences of nocturnal hypoglycaemia in patients treated with insulin glargine versus NPH insulin. All studies included in the metaanalysis (Eliaschewitz 2006; Fritsche 2003; Rosenstock 2001) found a statistically significant reduction in the number of patients experiencing nocturnal hypoglycaemia for the treatment with insulin glargine. The amount of this reduction was lowest in the study combining insulin glargine with short-acting premeal insulin (Rosenstock 2001). The additional effect of evening premeal insulin might be the reason for a higher rate of nocturnal hypoglycaemia in this study.

\section{Subgroup analyses}

Not performed due to lack of data.

\section{Sensitivity analyses}

As for pre-planned sensitivity analyses, those restricting for study quality and excluding unpublished studies were not done since all studies were of the same quality "C" and no unpublished trials were identified. Also, because all publications were in the English language and not significantly different in size, sensitivity analyses were not done for these items. The source of funding was commercial in five studies comparing insulin glargine to NPH insulin and unknown for one study. Since results were not heterogeneous with known and unknown sources of funding, no sensitivity analysis was performed. No sensitivity analysis was performed for studies investigating insulin detemir because only two studies were available. 


\section{Publication bias}

A formal assessment of publication bias was not performed due to the lack of data. Having considered only papers published in full text, publication bias cannot be excluded completely.

\section{DISCUSSION}

This systematic review and meta-analysis included eight studies comparing the effects of long-acting insulin analogues to NPH insulin in patients with type 2 diabetes mellitus. Six studies investigated insulin glargine and two insulin detemir.

No superiority in $\mathrm{HbA} 1 \mathrm{c}$ was observed for insulin glargine. For insulin detemir the meta-analysis yielded a statistically significant but clinically unimportant superiority of NPH insulin in metabolic control. Symptomatic and nocturnal hypoglycaemic events were lower in patients treated with insulin glargine than in patients with $\mathrm{NPH}$ therapy. Also, for insulin detemir the two included studies found a lower number of patients experiencing overall or nocturnal hypoglycaemic episodes in the insulin detemir treatment groups.

The methodological quality of the included studies allowed only a cautious interpretation of the results. Because only a small percentage of authors answered our request for additional information as yet, study quality assessment could not be substantially improved. Since personal correspondence with authors and companies is an ongoing process, any future information from these sources will be incorporated in future updates.

No study designed to investigate possible long-term effects was found. Therefore, it remains unclear if and to what extent the treatment with long-acting insulin analogues will affect the development and progression of microvascular and macrovascular events compared to results obtained with NPH insulin. Since the differences in overall effects on metabolic control were only small for insulin glargine and NPH and even disadvantageous for insulin detemir, no important improvements in the development of microvascular late complications would be expected from treatment with long-acting insulin analogues.

As for the advantages found in the rate of severe hypoglycaemic events some caution is warranted. No statistically significant advantage was found for therapy with insulin glargine or detemir. Also, interpretation of the results of the frequency of severe hypoglycaemia is difficult due to bias-prone definitions. Patients may inappropriately deny severe hypoglycaemia and in this context "third party help" is a soft and variable description of severity. More robust definitions as "injection of glucose or glucagon by another person" may result in more reliable data (Mühlhauser 1998). In all studies the frequency of severe hypoglycaemia was very low, making it unlikely to see an important clinical effect for the different treatments.
Even though the meta-analysis found a consistent reduction in symptomatic or overall hypoglycaemic effects for therapy with long-acting insulin analogues, no safe inferences can be drawn from these results because defining hypoglycaemia by symptoms only makes the results prone to bias, especially in open trials with (likely) no blinded outcome assessment.

The advantage of insulin glargine and detemir could be a lowering of nocturnal hypoglycaemic events in patients with type 2 diabetes mellitus and treatment with basal insulin. But again, bias cannot be ruled out and thus makes the interpretation of the results difficult.

No trial reported data on quality of life. One trial reported data on treatment satisfaction (Eliaschewitz 2006) and reported a more pronounced improvement in therapy satisfaction in patients treated with insulin glargine. The interpretation of the clinical importance of this result is hindered by the fact that baseline and end of trial values are reported even though the trialists claim a statistically significant improvement in the change of treatment satisfaction. Additionally, the reporting of this outcome was poor and therefore the assessment of the quality of this outcome was not possible.

Owing to the maximum observation period of 12 months, this review cannot provide any further guidance on potential adverse properties, such as mitogenic effects or progression of microvascular complications under treatment with long-acting insulin analogues. (For insulin glargine one study found a higher rate of progression of diabetic retinopathy in patients treated with insulin glargine, while in another investigation the opposite result was found.)

Since the mean age of patients in the included studies ranged from 55 to 62 years, no information on possible differences of the effects of the different insulins in old or in young patients, a growing group among patients with diabetes mellitus type 2 , can be derived from the studies at hand.

\section{A U THORS'CONCLUSIONS}

\section{Implications for practice}

Our analysis suggests, if at all only a minor clinical benefit of treatment with long-acting insulin analogues for patients with diabetes mellitus type 2 treated with "basal" insulin regarding symptomatic nocturnal hypoglycaemic events. Until long-term efficacy and safety data are available, we suggest a cautious approach to therapy with insulin glargine or detemir.

\section{Implications for research}

For safety purposes and judgment on the efficacy of long-acting insulin analogues in terms of diabetic late complications, we need 
a long-term follow-up of larger numbers of patients who use these insulins. Studies including young and old patients should be conducted. We also suggest a more uniform and more rigorous reporting of results from upcoming trials to warrant a better comparison and pooling of data and to enable safer inferences from these results.

\section{ACKNOW LEDGEMENTS}

We would like to thank Prof Haak, Prof Yokoyama, Prof YkiJärvinen, Prof Riddle and Dr. Laurent Vaur from Sanofi-Aventis for providing additional information on their trials.

\section{R E F E R E N C E S}

\section{References to studies included in this review}

\section{Eliaschewitz 2006 \{published data only\}}

Eliaschewitz FG, Calvo C, Valbuena H, Ruiz M, Aschner P, Villena J, et al.Therapy in type 2 diabetes: insulin glargine vs. NPH insulin both in combination with glimepiride. Archives of Medical Research 2006;37(4):495-501.

Fritsche 2003 \{published data only\}

Fritsche A, Schweitzer MA, Haring HU, Study Group. Glimepiride combined with morning insulin glargine, bedtime neutral protamine hagedorn insulin, or bedtime insulin glargine in patients with type 2 diabetes. A randomized, controlled trial.[see comment]. Annals of internal medicine 2003;138(12):952-9.

Haak 2005 \{published data only\}

Haak T, Tiengo A, Draeger E, Suntum M, Waldhausl W. Lower within-subject variability of fasting blood glucose and reduced weight gain with insulin detemir compared to $\mathrm{NPH}$ insulin in patients with type 2 diabetes. Diabetes, obesity \& metabolism 2005;7(1):56-64.

Hermansen 2006 \{published data only\}

Hermansen K, Davies M, Derezinski T, Martinez RG, Clauson P, Home P. A 26-week, randomized, parallel, treatto-target trial comparing insulin detemir with NPH insulin as add-on therapy to oral glucose-lowering drugs in insulinnaive people with type 2 diabetes. Diabetes care 2006;29(6): 1269-74.

Massi 2003 \{published data only\}

Massi BM, Humburg E, Dressler A, Ziemen M. A oneyear, randomised, multicentre trial comparing insulin glargine with NPH insulin in combination with oral agents in patients with type 2 diabetes. Hormone \& Metabolic Research 2003;35(3):189-96.

Yki-Jarvinen H, Dressler A, Ziemen M, Study Group. Less nocturnal hypoglycemia and better post-dinner glucose control with bedtime insulin glargine compared with bedtime NPH insulin during insulin combination therapy in type 2 diabetes. HOE 901/3002 Study Group. Diabetes care 2000;23(8):1130-6.

Riddle 2003 \{published data only\}

Riddle MC, Rosenstock J, Gerich J, Insulin G. The treatto-target trial: randomized addition of glargine or human NPH insulin to oral therapy of type 2 diabetic patients. Diabetes care 2003;26(11):3080-6.

Rosenstock 2001 \{published data only\} Fonseca V, Bell DS, Berger S, Thomson S, Mecca TE. A comparison of bedtime insulin glargine with bedtime neutral protamine hagedorn insulin in patients with type 2 diabetes: subgroup analysis of patients taking once-daily insulin in a multicenter, randomized, parallel group study. American Journal of the Medical Sciences 2004;328(5): 274-80.

Rosenstock J, Schwartz SL, Clark CM Jr, Park GD, Donley DW, Edwards MB. Basal insulin therapy in type 2 diabetes: 28-week comparison of insulin glargine (HOE 901) and NPH insulin. Diabetes care 2001;24(4):631-6.

Yki-Järvinen 2006 \{published data only\} Yki-Jarvinen H, Kauppinen-Makelin R, Tiikkainen M, Vahatalo M, Virtamo H, Nikkila K, et al.Insulin glargine or $\mathrm{NPH}$ combined with metformin in type 2 diabetes: The LANMET study. Diabetologia 2006;49(3):442-51.

Yokoyama 2006 \{published data only\} Yokoyama H, Tada J, Kamikawa F, Kanno S, Yokota Y, Kuramitsu M. Efficacy of conversion from bedtime NPH insulin to morning insulin glargine in type 2 diabetic patients on basal-prandial insulin therapy. Diabetes Research o Clinical Practice 2006;73(1):35-40.

\section{References to studies excluded from this review}

Cada 2005 \{published data only\}

Cada DJ, Levien T, Baker DE. Insulin detemir. Hospital Pharmacy 2005;40(12):1062-73. 
Garber 2003 \{published data only\}

Garber AJ. Benefits of combination therapy of insulin and oral hypoglycemic agents. Archives of Internal Medicine 2003;163(15):1781-2.

\section{Kacerovsky-Bielesz \{published data only\}} Authors Kacerovsky-Bielesz G, Dressler A, Freunscht, R. Long-term glycaemic control with insulin glargine in Type 2 diabetes. Diabetes Research \& Clinical Practice 2006;71: 184-91.

Kaplan 2004 \{published data only\}

Kaplan W, Rodriguez LM, Smith OE, Haymond MW, Heptulla RA. Effects of mixing glargine and short-acting insulin analogs on glucose control. Diabetes care 2004;27 (11):2739-40.

Krankenpflege 2004 \{published data only\}

Anonymous. Lantus is superior in BOT (basic oral therapy) to standard mixed insulin. Krankenpflege Journal 2004;42 (5-6):172.

Nakhmanovich 2001 \{published data only\} Nakhmanovich Y, Belenkaya R, Rozenfeld V. Insulin glargine in the management of diabetes mellitus. Pharmacy and Therapeutics 2001;26(4):176-81.

Riddle 2006 \{published data only\}

Riddle MC. The Treat-to-Target Trial and related studies. Endocrine Practice 2006;12 Suppl 1:71-9.

Stoneking 2005 \{published data only\} Stoneking K. Initiating basal insulin therapy in patients with type 2 diabetes mellitus. American Journal of HealthSystem Pharmacy 2005;62(5):510-8.

\section{References to studies awaiting assessment}

Kawamori 2003 \{published data only\}

Kawamori R, Iwamoto Y, Kadowaki T, Manabu Iwasaki. Efficacy and safety of insulin glargine in concurrent use with oral hypoglycemic agents for the treatment of Type 2 diabetes patients. Rinshoiyaku 2003;19(5):445-64.

\section{Additional references}

\section{Abraira 1997}

Abraira C, Colwell J, Nuttall F, Sawin CT, Henderson W, Comstock JP, et al.Cardiovascular events and correlates in the Veterans Affairs Diabetes Feasibility Trial. Veterans Affairs Cooperative Study on Glycemic Control and Complications in Type II Diabetes. Archives of internal medicine 1997;157(2):181-8.

Adler 1997

Adler AI, Boyko EJ, Ahroni JH, Stensel V, Forsberg RC, Smith DG. Risk factors for diabetic peripheral sensory neuropathy. Results of the Seattle Prospective Diabetic Foot Study. Diabetes Care 1997;20(7):1162-7.

\section{CCOHTA Detemir 2004}

Insulin detemir for diabetes mellitus. Ottawa: Canadian Coordinating Office for Health Technology Assessment (CCOHTA) 2004.

\section{CCOHTA Glargine 2004}

Insulin glargine for type 2 diabetes. Ottawa: Canadian Coordinating Office for Health Technology Assessment (CCOHTA) 2004.

\section{Chapman 2004}

Chapman TM, Perry CM. Insulin detemir: A review of its use in the management of type 1 and 2 diabetes mellitus. Drugs 2004;64(22):2577-95.

\section{Cohen 1960}

Cohen J. A coefficient of agreement for nominal scales. Educational and Psychological Measurement 1960;20:37-46.

Dunn 2003

Dunn CJ, Plosker GK, Keating GM, McKeage K, Scott LJ. Insulin glargine: an updated review of its use in the management of diabetes mellitus. Drugs 2003;63(16): 1743-78. [MEDLINE: DUNNCJ2003]

\section{EMEA 2003}

20. European Public Assessment Report (EPAR) on Lantus (Insulin Glargine) - Scientific Discussion (2003). http://www.emea.eu.int/humandocs/PDFs/EPAR/Lantus/ 061500en6.pdf (accessed 16 August 2006).

\section{EMEA 2004}

18. European Public Assessment Report (EPAR) on Levemir (Insulin Detemir) - Scientific Discussion (2004). http://www.emea.eu.int/humandocs/PDFs/EPAR/levemir/ 093604en6.pdf (accessed 16 August 2006).

FDA 2000

21.Center for Drug Evaluation and Research (CDER). Application Number 21-081: Lantus (Insulin Glargine) - Pharmacology Review(s) (2000). http://www.fda.gov/cder/foi/nda/2000/ 21081 Lantus' pharmr' P1.pdf und http://www.fda.gov/ cder/foi/nda/2000/21081 Lantus' pharmr' P2.pdf (accessed 16 August 2006).

\section{FDA 2005}

19.Center for Drug Evaluation and Research (CDER). Application Number 21-536: Levemir (Insulin Detemir) Pharmacology Review(s) (2005). http://www.fda.gov/cder/ foi/nda/2005/021-536 Levemir pharmr.PDF (accessed 16 August 2006).

\section{Grant 1993}

Grant MB, Mames RN, Fitzgerald C, Ellis EA, Aboufriekha $\mathrm{M}$, Guy J. Insulin-like growth factor I acts as an angiogenic agent in rabbit cornea and retina: comparative studies with basic fibroblast growth factor. Diabetologia 1993;36(4): 282-91. [MEDLINE: 23]

\section{Havelund 2004}

Havelund S, Plum A, Ribel U, Jonassen I, Volund A, Markussen J, et al.The mechanism of protraction of insulin detemir, a long-acting, acylated analog of human insulin. Pharmaceutical research 2004;21(8):1498-504. [MEDLINE: 1]

\section{Heinemann 2000}

Heinemann L, Linkeschova R, Rave K, Hompesch B, Sedlak M, Heise T. Time-action profile of the long-acting 
insulin analog insulin glargine (HOE901) in comparison with those of NPH insulin and placebo. Diabetes Care 2000;23(5):644-9. [MEDLINE: 5]

\section{Heise 2004}

Heise T, Nosek L, Ronn BB, Endahl L, Heinemann L, Kapitza C, et al.Lower within-subject variability of insulin detemir in comparison to NPH insulin and insulin glargine in people with type 1 diabetes. Diabetes 2004;53(6): 1614-20. [MEDLINE: 2]

\section{Higgins 2002}

Higgins JP, Thompson SG. Quantifying heterogeneity in a meta-analysis. Statistics in Medicine 2002;21(11):1539-58.

\section{Higgins 2003}

Higgins JPT, Thompson SG, Deeks JJ, Altman DG. Measuring inconsistency in meta-analysis. BMJ 2003;327: 557-60.

\section{Higgins 2005}

Higgins JPT, Green S, editors. Cochrane Handbook for Systematic Reviews of Interventions 4.2.5 [updated May 2005]. In: The Cochrane Library, Issue 3, 2005. Chichester, UK: John Wiley \& Sons, Ltd.

\section{Jadad 1996}

Jadad AR, Moore RA, Carroll D, Jenkinson C, Reynolds DJ, Gavaghan DJ, et al.Assessing the quality of reports of randomized clinical trials: is blinding necessary?. Controlled clinical trials 1996;17(1):1-12. [MEDLINE: 128]

\section{Jorgensen 1992}

Jorgensen LN, Didriksen LH, Drejer K. Cardinogen effect of the human insulin analogue B10 Asp in female rats. Diabetologia 1992;35:A3 (Abstract).

\section{King 1985}

King GL, Goodman AD, Buzney S, Moses A, Kahn CR. Receptors and growth-promoting effects of insulin and insulinlike growth factors on cells from bovine retinal capillaries and aorta. The Journal of clinical investigation 1985;75(3):1028-36. [MEDLINE: 17]

\section{Klein 1995}

Klein R. Hyperglycemia and microvascular and macrovascular disease in diabetes. Diabetes Care 1995;18 (2):258-68

\section{Kunz 1998}

Kunz R, Oxman AD. The unpredictability paradox: review of empirical comparisons of randomised and nonrandomised clinical trials. BMJ 1998;317(7167):1185-90. [MEDLINE: 123]

\section{Kurtzhals 2000}

Kurtzhals P, Schaffer L, Sorensen A, Kristensen C, Jonassen I, Schmid C, et al.Correlations of receptor binding and metabolic and mitogenic potencies of insulin analogs designed for clinical use. Diabetes 2000;49(6):999-1005. [MEDLINE: 21]
Lepore 2000

Lepore M, Pampanelli S, Fanelli C, Porcellati F, Bartocci L, Di VA, et al.Pharmacokinetics and pharmacodynamics of subcutaneous injection of long-acting human insulin analog glargine, NPH insulin, and ultralente human insulin and continuous subcutaneous infusion of insulin lispro. Diabetes 2000;49(12):2142-8. [MEDLINE: 3]

\section{Mühlhauser 1998}

Muehlhauser I, Overmann H, Bender R, Bott U, Berger M. Risk factors of severe hypoglycaemia in adult patients with Type 1 diabetes - a prospective population based study. Diabetologia 1998;41:1274-82.

\section{National 2002}

National Institute for Clinical Excellence. Guidance on the use of long-acting insulin analogues for the treatment of diabetes insulin glargine. United Kingdom: London: National Institute for Clinical Excellence (NICE), 2002. [MEDLINE: 104]

\section{Ohkubo 1995}

Ohkubo Y, Kishikawa H, Araki E, Miyata T, Isami S, Motoyoshi S, et al.Intensive insulin therapy prevents the progression of diabetic microvascular complications in Japanese patients with non-insulin-dependent diabetes mellitus: a randomized prospective 6-year study. Diabetes research and clinical practice 1995;28(2):103-17. [MEDLINE: 8]

\section{Rosenstock 2005}

Rosenstock J, Dailey G, Massi-Benedetti M, Fritsche A, Lin Z, Salzman A. Reduced hypoglycemia risk with insulin glargine: a meta-analysis comparing insulin glargine with human NPH insulin in type 2 diabetes. Diabetes Care 2005; 28(4):950-5. [MEDLINE: 71]

\section{Schulz 1995}

Schulz KF, Chalmers I, Hayes RJ, Altman DG. Empirical evidence of bias. Dimensions of methodological quality associated with estimates of treatment effects in controlled trials. JAMA 1995;273(5):408-12. [MEDLINE: 122]

\section{Turner 1998}

Turner RC, Millns H, Neil HA, Stratton IM, Manley SE, Matthews DR, et al.Risk factors for coronary artery disease in non-insulin dependent diabetes mellitus: United Kingdom Prospective Diabetes Study (UKPDS: 23)[. BMJ 1998;316(7134):823-8.

\section{UKPDS 341998}

UK Prospective Diabetes Study (UKPDS) Group. Effect of intensive blood-glucose control with metformin on complications in overweight patients with type 2 diabetes (UKPDS 34). The Lancet 1998;352(9131):854-65. [MEDLINE: 6]

* Indicates the major publication for the study 


\section{CHARACTERISTICS OF STUDIES}

\section{Characteristics of included studies [ordered by study ID]}

\section{Eliaschewitz 2006}

\begin{tabular}{|c|c|}
\hline Methods & $\begin{array}{l}\text { DURATION OF INTERVENTION: } 24 \text { weeks } \\
\text { RUN-IN PERIOD: N; } 4 \text { weeks screening phase } \\
\text { LANGUAGE OF PUBLICATION: English }\end{array}$ \\
\hline Participants & $\begin{array}{l}\text { WHO PARTCIPATED: type } 2 \text { diabetes patients poorly controlled on OADs } \\
\text { INCLUSION CRITERIA: men or women;age }=<75 \text {; } \mathrm{BMI}=<35 \mathrm{~kg} / \mathrm{m}^{2} \text {; type } 2 \text { diabetes mellitus; failed } \\
\text { to achieve good metabolic control on OADs (HbAlc levels }=>7.5 \% \text { and }=<10.5 \% \text {; FBG levels => } 100 \\
\mathrm{mg} / \mathrm{dL} \text {; patients required to have been receiving OADs (any sulphonylureas, including glimepiride, or } \\
\text { a combination of sulfonylureas with other OADs such as metformin or acarbose) for at least } 6 \text { month; } \\
\text { previous doses of sulfonylureas were required to have been at least equivalent to glimepiride } 3 \mathrm{mg} \text {; patients } \\
\text { needed to be willing to follow a tight antidiabetic therapy; women of childbearing age needed to use an } \\
\text { acceptable form of contraception } \\
\text { EXCLUSION CRITERIA: previous treatment with any insulin in the three month before the study; } \\
\text { pregnant or breastfeeding, likely to require treatment with drugs not permitted by the study protocol } \\
\text { (non-cardioselective B-blockers and systemic corticosteroids); enrolment in a previous study of insulin } \\
\text { glargine, received an investigative drug within three month of the study; had a history of alcohol abuse } \\
\text { DIAGNOSTIC CRITERIA: nr }\end{array}$ \\
\hline
\end{tabular}

\begin{tabular}{|c|c|}
\hline Interventions & $\begin{array}{l}\text { NUMBER OF STUDY CENTRES: } 56 \\
\text { COUNTRY/ LOCATION: Latin American countries } \\
\text { SETTING: nr } \\
\text { INTERVENTION (ROUTE, TOTAL DOSE/DAY, FREQUENCY): oral, glimepiride } 4 \mathrm{mg} / \text { day, once } \\
\text { in the morning plus subcutaneous, glargine, once at bedtime } \\
\text { CONTROL (ROUTE, TOTAL DOSE/DAY, FREQUENCY): oral, glimepiride } 4 \mathrm{mg} / \mathrm{day} \text {, once in the } \\
\text { morning plus subcutaneous, NPH insulin, once at bedtime } \\
\text { TREATMENT BEFORE STUDY: OADs (any sulfonylureas, including glimepiride, or a combination } \\
\text { of sulfonylureas with other OADs such as metformin or acarbose) equivalent to glimepiride } 3 \text { mg per day } \\
\text { for at least } 6 \text { month } \\
\text { TITRATION PERIOD: } 6 \text { weeks }\end{array}$ \\
\hline Outcomes & $\begin{array}{l}\text { PRIMARY OUTCOMES: change in HbA1c from baseline to end of study } \\
\text { SECONDARY OUTCOMES: percentage of patients who achieved a target HbA1c value of }=<7.5 \% \text { by } \\
\text { the end of the study; change in FBG; percentage of patients who achieved a FBG level }=<100 \mathrm{mg} / \mathrm{dL} \\
\text { by the end of the study; treatment satisfaction (DTSQc); pharmacoeconomics; safety } \\
\text { ADDITIONAL PUBLISHED OUTCOMES: unclear } \\
\text { TIMING OF OUTCOME MEASURES: unclear }\end{array}$ \\
\hline
\end{tabular}

Notes

STATED AIM OF STUDY: To compare the efficacy and safety of basal insulin therapy with insulin glargine with those of NPH insulin, both in combination with glimepiride in a predominantly non-white (>53\%) population of patients with type 2 diabetes living in Central and South America

\section{Risk of bias}

\begin{tabular}{l|l}
\hline Item & Authors' judgement
\end{tabular}


Eliaschewitz 2006 (Continued)

Allocation concealment? Unclear $\quad$ B - Unclear

Fritsche 2003

\begin{tabular}{|c|c|}
\hline Methods & $\begin{array}{l}\text { DURATION OF INTERVENTION: } \\
24 \text { weeks } \\
\text { RUN-IN PERIOD: } \\
4 \text { weeks screening phase; patients discontinued use of previous oral antidiabetic drug treatment and } \\
\text { received } 3 \text { mg glimepiride in the morning } \\
\text { LANGUAGE OF PUBLICATION: } \\
\text { English }\end{array}$ \\
\hline Participants & $\begin{array}{l}\text { WHO PARTCIPATED: patients with type } 2 \text { diabetes mellitus, who did not achieve good metabolic } \\
\text { control while receiving oral antidiabetic drugs } \\
\text { INCLUSION CRITERIA: type } 2 \text { diabetes mellitus, age }<75 \text { years; previous oral SU as monotherapy or } \\
\text { in combination with metformin or acarbose; } \mathrm{BMI}<35 \mathrm{~kg} / \mathrm{m}^{2} ; \mathrm{HbA} 1 \mathrm{c} 7.5-10.5 \% \text {; FPG }=<6.7 \mathrm{mmol} / \mathrm{L} \\
\text { EXCLUSION CRITERIA: pregnancy or breast-feeding; pre-treatment with insulin or any investigational } \\
\text { drugs within the previous } 3 \text { months; clinically relevant somatic or mental diseases } \\
\text { DIAGNOSTIC CRITERIA: ? }\end{array}$ \\
\hline Interventions & $\begin{array}{l}\text { NUMBER OF STUDY CENTRES: } \\
111 \\
\text { COUNTRY/ LOCATION: } \\
\text { Europe } \\
\text { SETTING: } \\
\text { ? } \\
\text { INTERVENTION (ROUTE, TOTAL DOSE/DAY, FREQUENCY): } \\
\text { I1:glargine once daily subcutaneously in the morning + } 3 \text { mg glimepiride } \\
\text { I2: glargine once daily subcutaneously at bedtime + } 3 \text { mg glimepiride } \\
\text { CONTROL (ROUTE, TOTAL DOSE/DAY, FREQUENCY): } \\
\text { NPH once daily subcutaneously at bedtime + } 3 \text { mg glimepiride } \\
\text { TREATMENT BEFORE STUDY: } \\
\text { SU as monotherapy or in combination with metformin or acarbose } \\
\text { TITRATION PERIOD: complete treatment phase; pre-specified algorithm; }\end{array}$ \\
\hline Outcomes & $\begin{array}{l}\text { PRIMARY OUTCOMES: change of HbA1c from baseline to end point; frequency of patients who } \\
\text { experienced hypoglycaemic events } \\
\text { SECONDARY OUTCOMES: HbA1c }<=7.5 \% \text {; FPG }<=5.6 \mathrm{mmol} / \mathrm{L} \text {; response rates; mean 24-hour } \\
\text { blood glucose values } \\
\text { ADDITIONAL PUBLISHED OUTCOMES. insulin doses; adverse events; body weight } \\
\text { TIMING OF OUTCOME MEASURES: } 24 \text { weeks }\end{array}$ \\
\hline Notes & $\begin{array}{l}\text { STATED AIM OF STUDY: to investigate the efficacy and safety of a combination therapy of SU with } \\
\text { either morning or bedtime insulin glargine in patients with diabetes mellitus type } 2 \text { whose diabetes was } \\
\text { poorly controlled with oral antidiabetic drugs }\end{array}$ \\
\hline
\end{tabular}

Risk of bias

Long-acting insulin analogues versus NPH insulin (human isophane insulin) for type 2 diabetes mellitus (Review) 
Fritsche 2003 (Continued)

\begin{tabular}{lll}
\hline Item & Authors' judgement & Description \\
\hline Allocation concealment? & Unclear & B - Unclear \\
\hline
\end{tabular}

Haak 2005

\begin{tabular}{ll} 
Methods & DURATION OF INTERVENTION: 26 weeks \\
& RUN-IN PERIOD: N, 3 weeks screening period \\
& LANGUAGE OF PUBLICATION: English \\
\hline Participants & WHO PARTCIPATED: patients with type 2 diabetes mellitus \\
& INCLUSION CRITERIA: type 2 diabetes mellitus $>=12$ months, age $>=35$ years; insulin treatment for \\
at least 2 months (basal insulin dose $>=30 \%$ of the total daily insulin dose); HbAlc $<=12 \%$ \\
EXCLUSION CRITERIA: pregnancy or breast-feeding; OADs within the previous 2 months; prolifer- \\
$\begin{array}{l}\text { ative retinopathy; uncontrolled hypertension; recurrent major hypoglycaemia; impaired renal or hepatic } \\
\text { function; cardiac problems; daily basal insulin dose }>100 \text { IU/day; }\end{array}$ \\
DIAGNOSTIC CRITERIA: ?
\end{tabular}

NUMBER OF STUDY CENTRES: 63
COUNTRY/ LOCATION: Europe SETTING: ?
INTERVENTION (ROUTE, TOTAL DOSE/DAY, FREQUENCY): detemir once daily subcutaneously
at bedtime or detemir twice daily in the morning and at bedtime + mealtime insulin aspart
CONTROL (ROUTE, TOTAL DOSE/DAY, FREQUENCY): NPH once daily subcutaneously at bed-
time or NPH twice daily in the morning and at bedtime + mealtime insulin aspart
TREATMENT BEFORE STUDY: insulin
TITRATION PERIOD: complete treatment phase; aiming for blood glucose targets pre-breakfast, post-
prandial and nocturnal

Outcomes $\quad$ PRIMARY OUTCOMES: HbA1c after 26 weeks of treatment SECONDARY

OUTCOMES: not specified

ADDITIONAL PUBLISHED OUTCOMES. FPG; self measured blood glucose profiles; within subject variation of FBG; insulin doses; percentage of patients experiencing a hypoglycaemic episode (overall, severe and nocturnal); body weight; adverse events; safety

TIMING OF OUTCOME MEASURES: 26 weeks

Notes

STATED AIM OF STUDY: efficacy and safety comparison of insulin detemir and NPH insulin in patients with type 2 diabetes on a basal-bolus regimen

Risk of bias

\begin{tabular}{l|ll}
\hline Item & Authors' judgement & Description \\
\hline Allocation concealment? & Yes & A - Adequate \\
\hline
\end{tabular}

Long-acting insulin analogues versus NPH insulin (human isophane insulin) for type 2 diabetes mellitus (Review) 


$\begin{array}{ll}\text { Methods } & \text { DURATION OF INTERVENTION: } 24 \text { weeks } \\ \text { RUN-IN PERIOD: N LANGUAGE OF } \\ \text { PUBLICATION: English }\end{array}$

WHO PARTCIPATED: insulin-naive people with type 2 diabetes mellitus
INCLUSION CRITERIA: insulin-naive people; age $>=18 \mathrm{yrs} ; \mathrm{BMI}<=35 \mathrm{~kg} / \mathrm{m}^{2} ; \mathrm{A} 1 \mathrm{c}$ of $7.5 \%$ to $10.0 \% ;$
type 2 diabetes mellitus for at least 12 months; inadequate control required at least 4 months treatment
with one or two OADs at doses at least half the recommended maximum or highest tolerated
EXCLUSION CRITERIA: use of thiazolidinediones; secondary diabetes, maturity-onset diabetes of the
young; proliferate retinopathy / maculopathy requiring treatment, hypoglycaemia unawareness or recur-
rent major hypoglycaemia, use of drugs affecting glycaemia, impaired hepatic or renal function; significant
cardiovascular disease. pregnancy, breast feeding
DIAGNOSTIC CRITERIA: $\mathrm{nr}$

\begin{tabular}{|c|c|}
\hline Interventions & $\begin{array}{l}\text { NUMBER OF STUDY CENTRES: } 58 \\
\text { COUNTRY/ LOCATION: } 10 \text { countries of the European Union } \\
\text { SETTING: nr } \\
\text { INTERVENTION (ROUTE, TOTAL DOSE/DAY, FREQUENCY): detemir (subcutaneous, individu- } \\
\text { ally titrated, twice daily) plus OAD (metformin, insulin secretagogues, alpha-glucosidase inhibitors) (oral, } \\
\text { dose unclear- remained unchanged during treatment period, frequency unclear) } \\
\text { CONTROL (ROUTE, TOTAL DOSE/DAY, FREQUENCY): NPH (subcutaneous, individually } \\
\text { titrated, twice daily) plus OAD (metformin, insulin secretagogues, alpha-glucosidase inhibitors) (oral, } \\
\text { dose unclear- remained unchanged during treatment period, frequency unclear) } \\
\text { TREATMENT BEFORE STUDY: one or two OADs (metformin, insulin secretagogues, alpha-glucosi- } \\
\text { dase inhibitors) at doses at least half the recommended maximum or highest tolerated } \\
\text { TITRATION PERIOD: } 24 \text { weeks }\end{array}$ \\
\hline Outcomes & $\begin{array}{l}\text { PRIMARY OUTCOMES: A1c } \\
\text { SECONDARY OUTCOMES: fasting plasma glucose (FPG); proportion of participants achieving A1c } \\
=<7.0 \% \text {; proportion of participants achieving target A1c value without hypoglycaemia (hypoglycaemia } \\
\text { defined as symptomatic episodes confirmed by a plasma glucose value }<72 \mathrm{mg} / \mathrm{dL} \text { or any single plasma } \\
\text { glucose value }<56 \mathrm{mg} / \mathrm{dL} \text { ); within-participant variation in self-measured pre-breakfast and pre-dinner } \\
\text { plasma glucose; self-measured } 10 \text {-point plasma glucose profile; adverse events } \\
\text { ADDITIONAL PUBLISHED OUTCOMES: N } \\
\text { TIMING OF OUTCOME MEASURES: } 24 \text { weeks }\end{array}$ \\
\hline
\end{tabular}

Notes

STATED AIM OF STUDY: To assess efficacy and tolerability of insulin detemir or NPH insulin added to oral therapy for type 2 diabetes in a treat-to-target titration protocol

\section{Risk of bias}

\begin{tabular}{l|ll}
\hline Item & Author' judgement & Description \\
\hline Allocation concealment? & Yes & A - Adequate \\
\hline
\end{tabular}



antidiabetic treatment, and were familiarised with the insulin delivery device and blood glucose meter LANGUAGE OF PUBLICATION: English

\begin{tabular}{|c|c|}
\hline Participants & $\begin{array}{l}\text { WHO PARTCIPATED: patients with type } 2 \text { diabetes mellitus } \\
\text { INCLUSION CRITERIA: diabetes duration of at least } 3 \text { years; men or women; age } 40 \text { - } 80 \text { years; oral } \\
\text { therapy with SU alone or in combination with acarbose, metformin, or metformin alone, or insulin once } \\
\text { daily plus oral antihyperglycaemic drugs for => } 1 \text { year; BMI }<40 \mathrm{~kg} / \mathrm{m} 2 \text {; HbAlc } 7.5 \text { to } 12.0 \% \text {; negative } \\
\text { history of ketoacidosis; } \\
\text { EXCLUSION CRITERIA: regular insulin therapy during the last four weeks before screening; diabetic } \\
\text { retinopathy with surgical treatment in the } 3 \text { months before study entry or requiring treatment within } \\
3 \text { months of study entry; night shift worker; treatment with any investigational drugs in the last } 2 \\
\text { months before study entry; clinically relevant cardiovascular, hepatic, neurologic, endocrine, or other } \\
\text { major systemic diseases that would make implementation of the study protocol or interpretation of the } \\
\text { study results difficult; drug or alcohol abuse; likelihood of requiring treatment during the study period } \\
\text { with drugs not permitted by the protocol; impaired hepatic function as shown by but not limited to } \\
\text { alanine aminotransferase or aspartate aminotransferase greater than twice the upper limit measured at } \\
\text { visit one; impaired renal function as shown by but not limited to serum creatinine }>1.5 \text { mg/dL; mental } \\
\text { condition rendering the subject unable to understand the nature, scope, and possible consequences of the } \\
\text { study; evidence of an uncooperative attitude; inability to attend follow up visits } \\
\text { DIAGNOSTIC CRITERIA: ? }\end{array}$ \\
\hline Interventions & $\begin{array}{l}\text { NUMBER OF STUDY CENTRES: } 57 \\
\text { COUNTRY/ LOCATION: Europe, South Africa } \\
\text { SETTING: ? } \\
\text { INTERVENTION (ROUTE, TOTAL DOSE/DAY, FREQUENCY): glargine once daily subcutaneously } \\
\text { at bedtime + previous oral antihyperglycaemic agents continued } \\
\text { CONTROL (ROUTE, TOTAL DOSE/DAY, FREQUENCY): NPH once daily subcutaneously at bed- } \\
\text { time + previous oral antihyperglycaemic agents continued } \\
\text { TREATMENT BEFORE STUDY: oral therapy with SU alone or in combination with acarbose, met- } \\
\text { formin, or metformin alone, or insulin once daily plus oral antihyperglycaemic drugs } \\
\text { TITRATION PERIOD: as needed according to self monitored FPG (optimal dose was defined by an } \\
\text { FPG target of } 6.66 \mathrm{~mol} / \mathrm{L} \text { over at least } 2-4 \text { days without nocturnal hypoglycaemia) }\end{array}$ \\
\hline
\end{tabular}
events; E. coli and insulin antibodies; insulin dose; body weight; safety parameters TIMING OF PUBLISHED OUTCOMES: 52 weeks

STATED AIM OF STUDY: to compare the effects of insulin glargine and NPH human insulin on glycated haemoglobin values, fasting plasma glucose and FBG levels, the blood glucose profile, hypoglycaemia, and safety for a treatment period of 52 weeks in patients with Type 2 diabetes. In regard to in- and exclusion criteria information from the present paper are scarce. Most of the information is available only from the paper by H. Yki-Järvinen which reports on the insulin naive subgroup. According to the FDA report and the publication by Yki-Järvinen eye examinations and fundoscopy were done. No results concerning retinopathy are presented in the papers at hand 


\section{Risk of bias}

\begin{tabular}{|c|c|c|}
\hline Item & Authors' judgement & Description \\
\hline Allocation concealment? & Yes & A - Adequate \\
\hline
\end{tabular}

Riddle 2003

Methods

DURATION OF INTERVENTION: 24 weeks

RUN-IN PERIOD: 4 weeks; treatment?

LANGUAGE OF PUBLICATION: English

Participants

WHO PARTCIPATED: patients with type 2 diabetes mellitus

INCLUSION CRITERIA: men or women; age 30 to 70 years; stable dose of one or two oral antihyperglycaemic agents (SU, metformin, glitazone) for >= 3 months; BMI 26 to $40 \mathrm{~kg} / \mathrm{m} 2$; HbA1c $7.5 \%$ to 10 . $0 \%$; FPG > $>7.8 \mathrm{mmol} / \mathrm{L}$

EXCLUSION CRITERIA: prior use of insulin (except for gestational diabetes < 1 week); current use of alpha-glucosidase inhibitor or rapid-acting insulin secretagogues; use of other agents affecting glycaemic control; history of ketoacidosis or inability to recognise hypoglycaemia; history of drug or alcohol abuse; serum alanine or aspartate aminotransferase more than twofold above upper limit; serum creatinine $=>1$, $5 \mathrm{mg} / \mathrm{dL}(\mathrm{m})$ or $1,4 \mathrm{mg} / \mathrm{dL}(\mathrm{f})$; positive test for GAD antibody; fasting plasma C-peptide $<=0.25 \mathrm{pmol} /$ $\mathrm{mL}$

DIAGNOSTIC CRITERIA: ?

NUMBER OF STUDY CENTRES: 80
COUNTRY/ LOCATION: US, Canada
SETTING: ?
INTERVENTION (ROUTE, TOTAL DOSE/DAY, FREQUENCY): glargine once daily subcutaneously
at bedtime + oral antihyperglycaemic agents (SU, metformin, glitazones) continued at pre-study dosages
CONTROL (ROUTE, TOTAL DOSE/DAY, FREQUENCY): NPH once daily subcutaneously at bed-
time + oral antihyperglycaemic agents (SU, metformin, glitazones) continued at pre-study dosages
TREATMENT BEFORE STUDY: one or two oral antihyperglycaemic agents (SU, metformin, piogli-
tazone, rosiglitazone)
TITRATION PERIOD: as needed to achieve target FPG $<=5.6 \mathrm{mmol} / \mathrm{L}$ (predefined algorithm)

Outcomes

PRIMARY OUTCOME

percentage of subjects achieving HbA1c $<=7.0 \%$ without a single instance of symptomatic nocturnal hypoglycaemia confirmed by plasma-referenced glucose $<=4 \mathrm{mmol} / \mathrm{L}$ or meeting criteria for severe hypoglycaemia or both

SECONDARY OUTCOME

changes from baseline for HbA1c, FPG and weight; percentage of subjects achieving HbA1c $<=7.0 \%$ or FPG $<=5.6 \mathrm{mmolL}$ independent of occurrence of hypoglycaemia; subjects achieving FPG $<=5.6$ $\mathrm{mmol} / \mathrm{L}$ without confirmed hypoglycaemia; with-in subject variability between seven sequential fasting glucose measures; rates of symptomatic hypoglycaemia including unconfirmed, confirmed and severe hypoglycaemia;

ADDITIONAL PUBLISHED OUTCOMES.

$\mathrm{N}$

TIMING OF PUBLISHED OUTCOMES: 
Riddle 2003 (Continued)

24 weeks

\begin{tabular}{ll}
\hline Notes & $\begin{array}{l}\text { STATED AIM OF STUDY: to compare the abilities of glargine and NPH to reduce HbA1c to } 7 \% \text { when } \\
\text { added to ongoing oral therapy and the hypoglycaemia accompanying this effort using a simple algorithm } \\
\text { for insulin dosage titration seeking a FPG target of } 5.6 \mathrm{mmol} / \mathrm{L}\end{array}$ \\
\hline
\end{tabular}

Risk of bias

\begin{tabular}{l|ll}
\hline Item & Authors' judgement & Description \\
\hline Allocation concealment? & Yes & A - Adequate \\
\hline
\end{tabular}

Rosenstock 2001

\begin{tabular}{ll}
\hline Methods & DURATION OF INTERVENTION: 28 weeks \\
RUN-IN PERIOD: N LANGUAGE OF \\
PUBLICATION: English
\end{tabular}

Outcomes

PRIMARY OUTCOME: change of HbA1c from baseline to end point

SECONDARY OUTCOME: changes from baseline for FBG at weeks 8, 20, 28, and at study end point (mean self monitored blood glucose values on 7 consecutive days before study visits); hypoglycaemia ADDITIONAL PUBLISHED OUTCOMES: insulin doses; adverse events; insulin antibody levels; body weight TIMING OF PUBLISHED OUTCOMES: 28 weeks

Notes

STATED AIM OF STUDY: to compare the safety and effectiveness of once daily insulin glargine with once or twice daily NPH insulin in patients who were not taking oral agents and who had previously received basal insulin with or without regular insulin for postprandial glycaemic control According to the EMEA report :“...additional antidiabetic treatment was provided by oral antidiabetic drugs.” 
Rosenstock 2001 (Continued)

\section{Risk of bias}

\begin{tabular}{l|l} 
Item Authors' judgement $\quad$ Description
\end{tabular}

Allocation concealment? Yes $\quad$ A - Adequate

Yki-Järvinen 2006

\begin{tabular}{|c|c|}
\hline Methods & $\begin{array}{l}\text { DURATION OF INTERVENTION: } 36 \text { weeks } \\
\text { RUN-IN PERIOD: } 4 \text { weeks } \\
\text { LANGUAGE OF PUBLICATION: English }\end{array}$ \\
\hline Participants & $\begin{array}{l}\text { WHO PARTCIPATED: poorly controlled type } 2 \text { diabetes patients on oral hypoglycaemic agents } \\
\text { INCLUSION CRITERIA: male or female; age } 35 \text { to } 75 \text { years; type } 2 \text { diabetes mellitus; had been treated } \\
\text { with a stable dose of sulfonylurea (any dose) and metformin ( }>=1.5 \mathrm{~g} \text { ) or with metformin alone for at } \\
\text { least } 3 \text { months; BMI } 20 \text { to } 40 \mathrm{~kg} / \mathrm{m} 2 \text {; HbA1c }>=8.0 \% \text {; mean fasting plasma glucose }>=7 \mathrm{mmol} / \mathrm{L} \text { (daily } \\
\text { home glucose monitoring); fasting C-peptide }>=0.33 \mathrm{nmol} / \mathrm{L} \text { (reference range } 0.33 \text { to } 0.69 \mathrm{nmol} / \mathrm{L} \text { ) } \\
\text { EXCLUSION CRITERIA: other oral antihyperglycaemic agents; prior use of insulin; positive GAD } \\
\text { antibodies; history of ketoacidosis; non-compliance with regard to daily measurements of FPG in the run } \\
\text { in phase, abnormal safety laboratory tests; current or past history of alcohol or drug abuse; night shift- } \\
\text { work; pregnancy; treatment with any investigational drug in the past } 2 \text { month prior start of trial; use of } \\
\text { drugs likely to interfere with glucose control; clinically relevant major systemic disease other than diabetes; } \\
\text { diabetic retinopathy requiring surgical (laser or other) treatment in the } 3 \text { months before or during the } \\
\text { study } \\
\text { DIAGNOSTIC CRITERIA: nr }\end{array}$ \\
\hline
\end{tabular}

Interventions $\quad$ NUMBER OF STUDY CENTRES: 7

COUNTRY/ LOCATION: Six sites in Finland, one in UK

SETTING: $\mathrm{nr}$

INTERVENTION (ROUTE, TOTAL DOSE/DAY, FREQUENCY): glargine (subcutaneous, individually titrated, once at bedtime) plus metformin (oral, dose unclear [abstract $2 \mathrm{~g}$ ], frequency unclear)

CONTROL (ROUTE, TOTAL DOSE/DAY, FREQUENCY): NPH (subcutaneous, individually, once at bedtime) plus metformin (oral, dose unclear [abstract $2 \mathrm{~g}$ ], frequency unclear)

TREATMENT BEFORE STUDY: oral antihyperglycaemic agents: sulfonylurea and metformin or metformin alone; with a stable dose

TITRATION PERIOD: nr

Outcomes

PRIMARY OUTCOMES: Change in HbAlc from baseline to end of study

SECONDARY OUTCOMES: diurnal glucose concentrations; symptomatic hypoglycaemia; weight; S-

ALT; triglycerides; insulin doses between groups

ADDITIONAL PUBLISHED OUTCOMES. fasting plasma glucose, adverse events

TIMING OF OUTCOME MEASURES: 36 weeks

Notes

STATED AIM OF STUDY: To compare the combination therapy insulin glargine plus metformin with

$\mathrm{NPH}$ insulin plus metformin

\section{Risk of bias}

Long-acting insulin analogues versus NPH insulin (human isophane insulin) for type 2 diabetes mellitus (Review)

Copyright @ 2009 The Cochrane Collaboration. Published by John Wiley \& Sons, Ltd. 
Yki-Järvinen 2006 (Continued)

\begin{tabular}{lll}
\hline Item & Authors' judgement & Description \\
\hline Allocation concealment? & Unclear & B - Unclear \\
\hline
\end{tabular}

Yokoyama 2006

\begin{tabular}{|c|c|}
\hline Methods & $\begin{array}{l}\text { DURATION OF INTERVENTION: } \\
6 \text { months } \\
\text { RUN-IN PERIOD: } \\
3 \text { months } \\
\text { LANGUAGE OF PUBLICATION: } \\
\text { English }\end{array}$ \\
\hline Participants & $\begin{array}{l}\text { WHO PARTCIPATED: intensively treated type } 2 \text { diabetes patients } \\
\text { INCLUSION CRITERIA: type } 2 \text { diabetes mellitus; } 2 \text { years duration of diabetes mellitus; age }>=35 \text {; } \\
\text { negative GAD test; without any episodes of ketoacidosis; BMI }<=40 \mathrm{~kg} / \mathrm{m}^{2} ; \mathrm{HbAlc}<=10 \% \text {; patients } \\
\text { had once poor glycaemic control (HbAlc ? 8\%) despite optimal dose of sulfonylureas in addition to diet } \\
\text { and exercise; for more than } 1 \text { year on basal/prandial insulin therapy using aspart / lispro at each meal and } \\
\text { NPH at bedtime with or without any anti-diabetic oral agents } \\
\text { EXCLUSION CRITERIA: impaired hepatic, renal or cardiac function; recurrent major hypoglycaemia } \\
\text { DIAGNOSTIC CRITERIA: nr }\end{array}$ \\
\hline Interventions & $\begin{array}{l}\text { NUMBER OF STUDY CENTRES: } 1 \\
\text { COUNTRY/ LOCATION: Japan } \\
\text { SETTING: outpatient clinic } \\
\text { INTERVENTION (ROUTE, TOTAL DOSE/DAY, FREQUENCY): glargine at breakfast, subcutaneous } \\
\text { (total dose should be } 50 \% \text { of the total daily insulin dose, once) plus mealtime aspart / lispro subcutaneous, } \\
\text { (individually titrated, at each meal); additional treatment with oral antihyperglycaemic agents was possible } \\
\text { (oral, dose unclear, frequency unclear) } \\
\text { CONTROL (ROUTE, TOTAL DOSE/DAY, FREQUENCY): NPH at bedtime, subcutaneous plus } \\
\text { mealtime aspart / lispro, subcutaneous, (individually titrated, at each meal); additional treatment with } \\
\text { oral antihyperglycaemic agents was possible (oral, dose unclear, frequency unclear) } \\
\text { TREATMENT BEFORE STUDY: sulfonylureas in addition to diet and exercise then having been treated } \\
\text { for more than a year with basal-prandial insulin therapy using aspart / lispro at each meal and NPH at } \\
\text { bedtime with or without OADs } \\
\text { TITRATION PERIOD: nr }\end{array}$ \\
\hline Outcomes & $\begin{array}{l}\text { PRIMARY OUTCOMES: HbA1c (not specified in publication) } \\
\text { SECONDARY OUTCOMES: total daily insulin dose; fasting and postprandial blood glucose; BMI; } \\
\text { hypoglycaemia } \\
\text { ADDITIONAL PUBLISHED OUTCOMES: NA } \\
\text { TIMING OF OUTCOME MEASURES: } 6 \text { months }\end{array}$ \\
\hline Notes & $\begin{array}{l}\text { STATED AIM OF STUDY: To investigate if increasing the dose of morning glargine up to half the total } \\
\text { insulin requirement may lead to better glycaemic control }\end{array}$ \\
\hline
\end{tabular}

Risk of bias

Long-acting insulin analogues versus NPH insulin (human isophane insulin) for type 2 diabetes mellitus (Review) 
Yokoyama 2006 (Continued)

\begin{tabular}{l|ll}
\hline Item & Author' judgement & Description \\
\hline Allocation concealment? & Unclear & B - Unclear \\
\hline
\end{tabular}

OAD: oral antihyperglycaemic drug; ?: unclear; GAD: glutamic acid decarboxylase; FBG: fasting blood glucose; nr: not reported; DTSQc: Diabetes Treatment Satisfaction Questionaire; SU: sulfonylurea; FP(B)G: fasting plasma (blood) glucose; N: no, BMI: body mass index; FDA: Food and Drug Administration; S-ALT: serum alanin aminotrasferase; EMEA: european Medicines Agency; na: not applicable

Characteristics of excluded studies [ordered by study ID]

\begin{tabular}{l|l}
\hline Study & Reason for exclusion \\
\hline Cada 2005 & not a randomised controlled trial \\
\hline Garber 2003 & not a randomised controlled trial \\
\hline Kacerovsky-Bielesz & extension study of Massi 2003 under non-randomised conditions \\
\hline Kaplan 2004 & no patients with type 2 diabetes \\
\hline Krankenpflege 2004 & different antihyperglycaemic co-therapy in the treatment arms \\
\hline Nakhmanovich 2001 & not a randomised controlled trial \\
\hline Riddle 2006 & not a randomised controlled trial \\
\hline Stoneking 2005 & not a randomised controlled trial \\
\hline
\end{tabular}

Characteristics of studies awaiting assessment [ordered by study ID]

\section{Kawamori 2003}

Methods Through communication with Sanofi-Aventis we became aware of one additional study comparing insulin glargine with NPH insulin in patients with type 2 diabetes mellitus (Kawamori 2003), which was not listed in any of the electronic databases searched. Unfortunately, the publication was not available in time for inclusion in this review. We therefore will assess its relevance in the next update of this review

Participants

Interventions

Outcomes

Long-acting insulin analogues versus NPH insulin (human isophane insulin) for type 2 diabetes mellitus (Review)

Copyright @ 2009 The Cochrane Collaboration. Published by John Wiley \& Sons, Ltd. 
Kawamori 2003 (Continued)

Notes

Long-acting insulin analogues versus NPH insulin (human isophane insulin) for type 2 diabetes mellitus (Review)

Copyright () 2009 The Cochrane Collaboration. Published by John Wiley \& Sons, Ltd. 
DATA AND ANALYSES

\section{Comparison 1. Hypoglycaemia}

\begin{tabular}{|c|c|c|c|c|}
\hline Outcome or subgroup title & $\begin{array}{l}\text { No. of } \\
\text { studies }\end{array}$ & $\begin{array}{c}\text { No. of } \\
\text { participants }\end{array}$ & Statistical method & Effect size \\
\hline $\begin{array}{l}1 \text { Severe hypoglycaemia - Glargine } \\
\text { vs. NPH }\end{array}$ & 4 & 2207 & Peto Odds Ratio (Peto, Fixed, 95\% CI) & $0.70[0.40,1.23]$ \\
\hline $\begin{array}{l}2 \text { Severe hypoglycaemia - Detemir } \\
\text { vs. NPH }\end{array}$ & 2 & 980 & Peto Odds Ratio (Peto, Fixed, 95\% CI) & $0.50[0.18,1.38]$ \\
\hline $\begin{array}{l}3 \text { Symptomatic hypoglycaemia - } \\
\text { Glargine vs. NPH }\end{array}$ & 3 & 1458 & Risk Ratio (M-H, Random, 95\% CI) & $0.84[0.75,0.95]$ \\
\hline $\begin{array}{l}4 \text { Overall hypoglycaemia - } \\
\text { Detemir vs. NPH }\end{array}$ & 2 & 980 & Risk Ratio (M-H, Random, 95\% CI) & $0.82[0.74,0.90]$ \\
\hline $\begin{array}{l}5 \text { Nocturnal hypoglycaemia - } \\
\text { Glargine vs. NPH }\end{array}$ & 3 & 1458 & Risk Ratio (M-H, Random, 95\% CI) & $0.66[0.55,0.80]$ \\
\hline $\begin{array}{l}6 \text { Nocturnal hypoglycaemia - } \\
\text { Detemir vs. NPH }\end{array}$ & 2 & 980 & Risk Ratio (M-H, Random, 95\% CI) & $0.63[0.52,0.76]$ \\
\hline
\end{tabular}

\section{Comparison 2. HbAlc}

\begin{tabular}{lcccc} 
Outcome or subgroup title & $\begin{array}{c}\text { No. of } \\
\text { studies }\end{array}$ & $\begin{array}{c}\text { No. of } \\
\text { participants }\end{array}$ & Statistical method & Effect size \\
\hline $\begin{array}{l}\text { 1 Change in HbA1c - Glargine vs. } \\
\text { NPH }\end{array}$ & 4 & 1568 & Mean Difference (IV, Random, 95\% CI) & $0.05[-0.08,0.17]$ \\
$\begin{array}{l}2 \text { Change in HbA1c (pooled SD) - } \\
\text { Glargine vs. NPH }\end{array}$ & 6 & 2902 & Mean Difference (IV, Random, 95\% CI) & $-0.00[-0.10,0.09]$ \\
$\begin{array}{l}\text { 3 Change in HbA1c - Detemir vs. } \\
\text { NPH }\end{array}$ & 2 & 967 & Mean Difference (IV, Random, 95\% CI) & $0.12[0.01,0.23]$ \\
$\begin{array}{l}\text { 4 Change in HbA1c (pooled SD) - } \\
\text { Detemir vs. NPH }\end{array}$ & 2 & 967 & Mean Difference (IV, Random, 95\% CI) & 0.15 [-0.02, 0.32] \\
\hline
\end{tabular}




\section{Analysis I.I. Comparison I Hypoglycaemia, Outcome I Severe hypoglycaemia - Glargine vs. NPH.}

Review: Long-acting insulin analogues versus NPH insulin (human isophane insulin) for type 2 diabetes mellitus

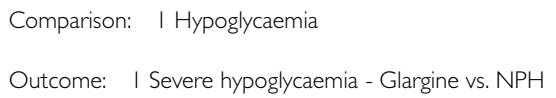

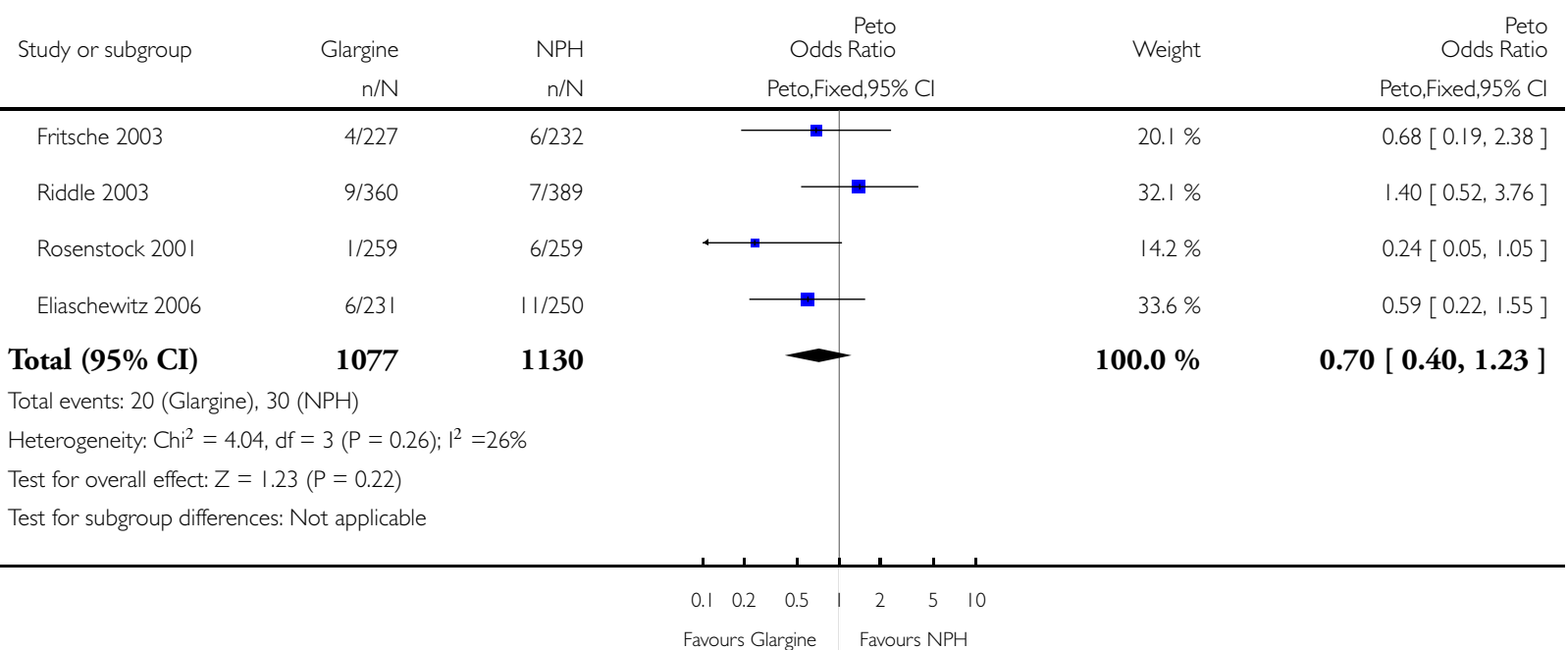




\section{Analysis I.2. Comparison I Hypoglycaemia, Outcome 2 Severe hypoglycaemia - Detemir vs. NPH.}

Review: Long-acting insulin analogues versus NPH insulin (human isophane insulin) for type 2 diabetes mellitus

Comparison: I Hypoglycaemia

Outcome: 2 Severe hypoglycaemia - Detemir vs. NPH

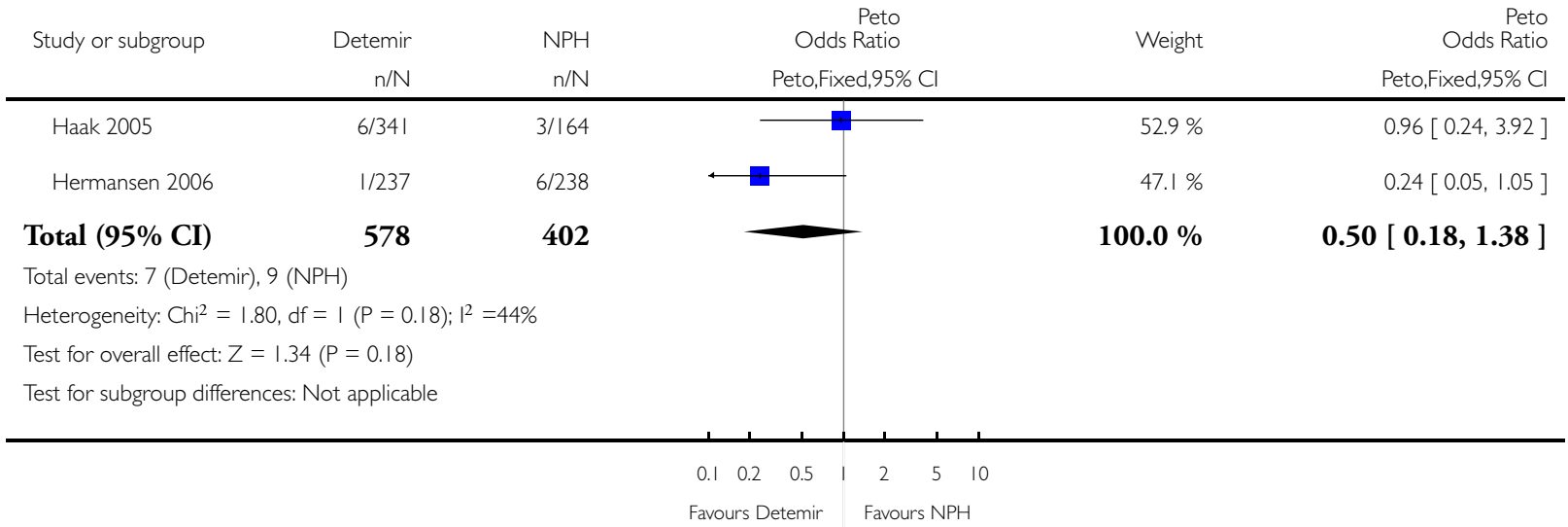

Analysis I.3. Comparison I Hypoglycaemia, Outcome 3 Symptomatic hypoglycaemia - Glargine vs. NPH.

Review: Long-acting insulin analogues versus NPH insulin (human isophane insulin) for type 2 diabetes mellitus

Comparison: I Hypoglycaemia

Outcome: 3 Symptomatic hypoglycaemia - Glargine vs. NPH

\begin{tabular}{ccr} 
& $n / N$ & $n / N$ \\
\hline Rosenstock 200I & $159 / 259$ & $173 / 259$ \\
Fritsche 2003 & $98 / 227$ & $135 / 232$ \\
Eliaschewitz 2006 & $122 / 231$ & $157 / 250$ \\
Total (95\% CI) & $\mathbf{7 1 7}$ & $\mathbf{7 4 1}$
\end{tabular}

Risk Ratio

H,Random,95\%

Weight

Risk Ratio

H,Random, $95 \%$

Total events: 379 (Glargine), 465 (NPH)

Heterogeneity: $\mathrm{Tau}^{2}=0.00 ; \mathrm{Chi}^{2}=3.57, \mathrm{df}=2(\mathrm{P}=0.17) ; \mathrm{I}^{2}=44 \%$

Test for overall effect: $Z=2.82(P=0.0048)$

$40.0 \% \quad 0.92[0.81,1.05]$

232

$26.8 \%$

$0.74[0.62,0.89]$

$33.2 \%$

$0.84[0.72,0.98]$

$+$

$100.0 \%$

$0.84[0.75,0.95]$

\section{$\begin{array}{lllll}0.2 & 0.5 & 1 & 2 & 5\end{array}$ \\ Favours Glargine Favours NPH}




\section{Analysis I.4. Comparison I Hypoglycaemia, Outcome 4 Overall hypoglycaemia - Detemir vs. NPH.}

Review: Long-acting insulin analogues versus NPH insulin (human isophane insulin) for type 2 diabetes mellitus

Comparison: I Hypoglycaemia

Outcome: 4 Overall hypoglycaemia - Detemir vs. NPH

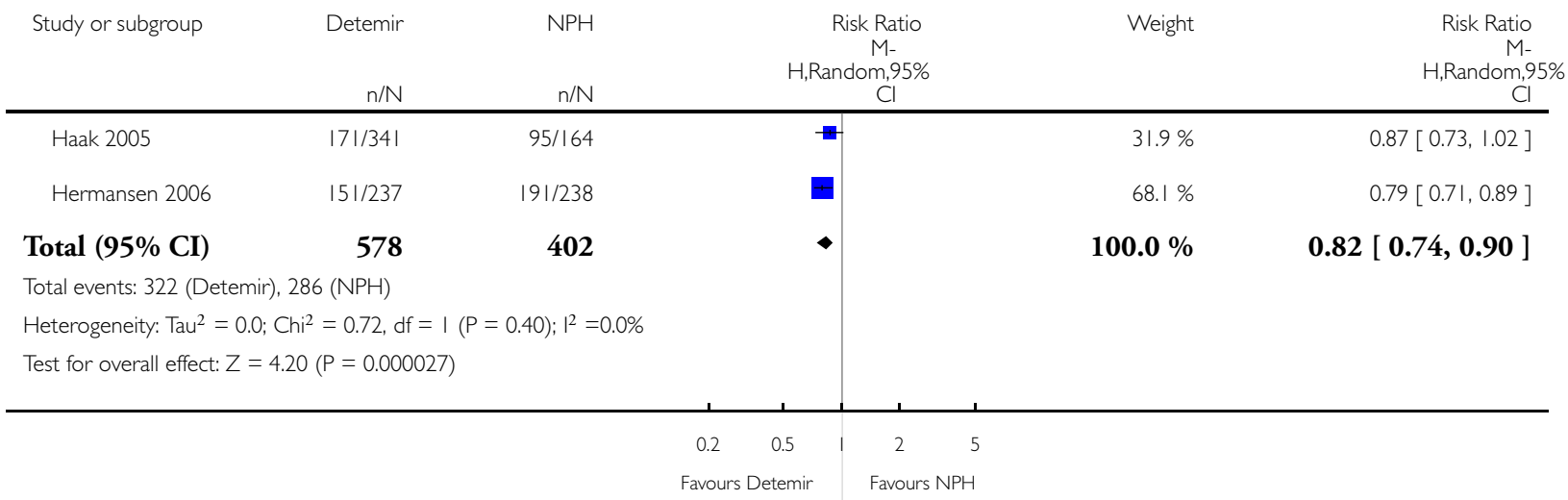




\section{Analysis I.5. Comparison I Hypoglycaemia, Outcome 5 Nocturnal hypoglycaemia - Glargine vs. NPH.}

Review: Long-acting insulin analogues versus NPH insulin (human isophane insulin) for type 2 diabetes mellitus

Comparison: I Hypoglycaemia

Outcome: 5 Nocturnal hypoglycaemia - Glargine vs. NPH

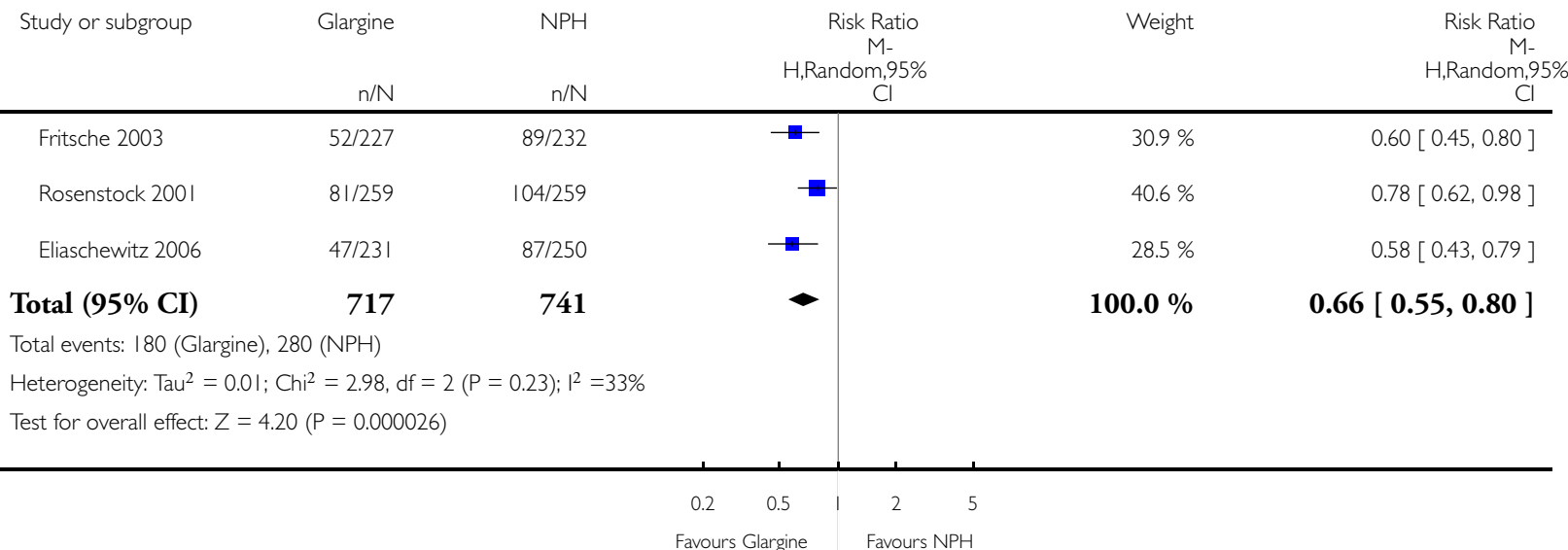

Analysis I.6. Comparison I Hypoglycaemia, Outcome 6 Nocturnal hypoglycaemia - Detemir vs. NPH.

Review: Long-acting insulin analogues versus NPH insulin (human isophane insulin) for type 2 diabetes mellitus

Comparison: I Hypoglycaemia

Outcome: 6 Nocturnal hypoglycaemia - Detemir vs. NPH

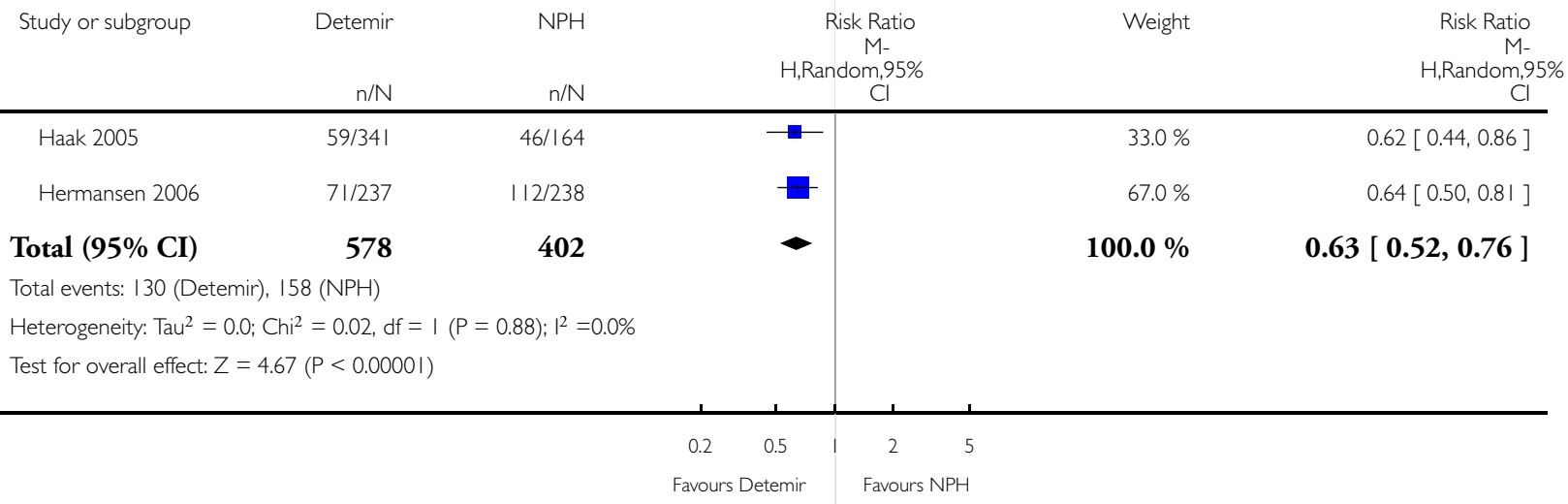

Long-acting insulin analogues versus NPH insulin (human isophane insulin) for type 2 diabetes mellitus (Review)

Copyright (C) 2009 The Cochrane Collaboration. Published by John Wiley \& Sons, Ltd. 


\section{Analysis 2.I. Comparison $2 \mathrm{HbAlc}$, Outcome I Change in HbAlc - Glargine vs. NPH.}

Review: Long-acting insulin analogues versus NPH insulin (human isophane insulin) for type 2 diabetes mellitus

Comparison: $2 \mathrm{HbAlc}$

Outcome: I Change in HbAlc - Glargine vs. NPH

\begin{tabular}{|c|c|c|c|c|c|c|c|c|}
\hline \multirow[t]{2}{*}{ Study or subgroup } & \multirow{2}{*}{$\begin{array}{r}\text { Glargine } \\
\mathrm{N}\end{array}$} & \multicolumn{3}{|c|}{$\mathrm{NPH}$} & \multicolumn{2}{|r|}{$\begin{array}{r}\text { Mean } \\
\text { Difference }\end{array}$} & \multirow[t]{2}{*}{ Weight } & \multirow{2}{*}{$\begin{array}{r}\text { Mean } \\
\text { Difference } \\
\text { IV,Random,95\% Cl }\end{array}$} \\
\hline & & Mean(SD) & $\mathrm{N}$ & Mean(SD) & & IV,Random,95\% Cl & & \\
\hline Rosenstock 200 I & 259 & $-0.4 \mid(\mid .61)$ & 259 & $-0.59(1.61)$ & & \pm & $21.8 \%$ & $0.18[-0.10,0.46]$ \\
\hline Fritsche 2003 & 227 & $-0.96(1.32)$ & 232 & $-0.84(1.34)$ & & $\rightarrow$ & $28.3 \%$ & $-0.12[-0.36,0.12]$ \\
\hline Eliaschewitz 2006 & 231 & $-1.38(1.32)$ & 250 & $-1.44(1.33)$ & & 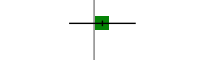 & $29.9 \%$ & $0.06[-0.18,0.30]$ \\
\hline Yki-Järvinen 2006 & 61 & $-1.99(0.85)$ & 49 & $-2.1(0.7)$ & & \pm & $20.0 \%$ & $0.11[-0.18,0.40]$ \\
\hline Total (95\% CI) & 778 & & 790 & & & - & $100.0 \%$ & $0.05[-0.08,0.17]$ \\
\hline \multirow{2}{*}{\multicolumn{9}{|c|}{$\begin{array}{l}\text { Heterogeneity: } \mathrm{Tau}^{2}=0.0 ; \mathrm{Chi}^{2}=2.89, \mathrm{df}=3(\mathrm{P}=0.4 \mathrm{I}) ; \mathrm{I}^{2}=0.0 \% \\
\text { Test for overall effect: } Z=0.68(P=0.49)\end{array}$}} \\
\hline & & & & & & & & \\
\hline & & & & & -1 & 0.5 & । & \\
\hline & & & & & Favou & Favours & & \\
\hline
\end{tabular}




\section{Analysis 2.2. Comparison 2 HbAlc, Outcome 2 Change in HbAlc (pooled SD) - Glargine vs. NPH.}

Review: Long-acting insulin analogues versus NPH insulin (human isophane insulin) for type 2 diabetes mellitus

Comparison: $2 \mathrm{HbAlc}$

Outcome: 2 Change in HbAlc (pooled SD) - Glargine vs. NPH

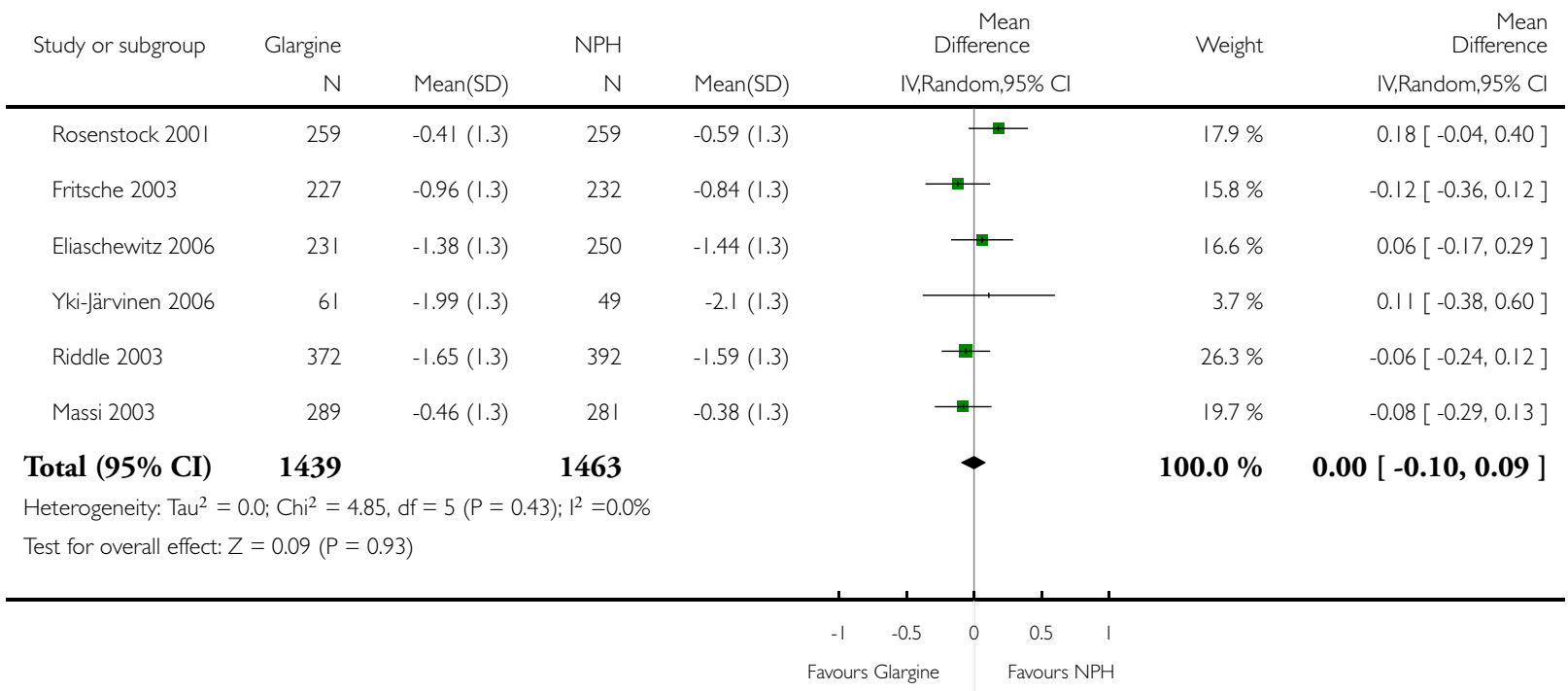




\section{Analysis 2.3. Comparison 2 HbAlc, Outcome 3 Change in HbAlc - Detemir vs. NPH.}

Review: Long-acting insulin analogues versus NPH insulin (human isophane insulin) for type 2 diabetes mellitus

Comparison: $2 \mathrm{HbAlc}$

Outcome: 3 Change in HbAlc - Detemir vs. NPH

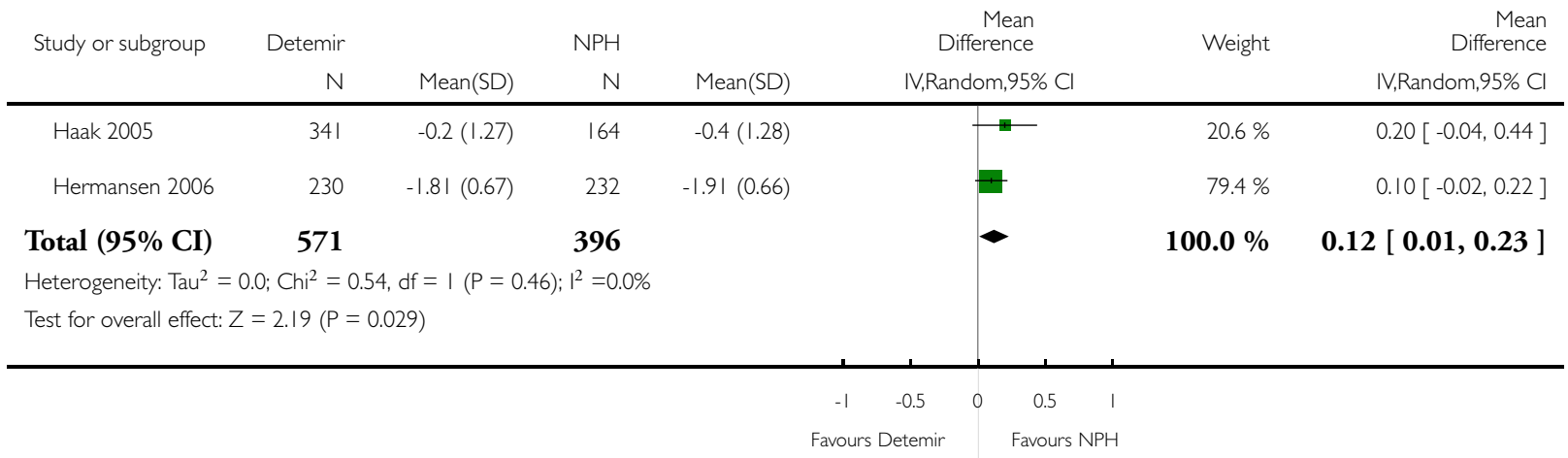

\section{Analysis 2.4. Comparison 2 HbAlc, Outcome 4 Change in HbAlc (pooled SD) - Detemir vs. NPH.}

Review: Long-acting insulin analogues versus NPH insulin (human isophane insulin) for type 2 diabetes mellitus

Comparison: $2 \mathrm{HbAlc}$

Outcome: 4 Change in HbAlc (pooled SD) - Detemir vs. NPH

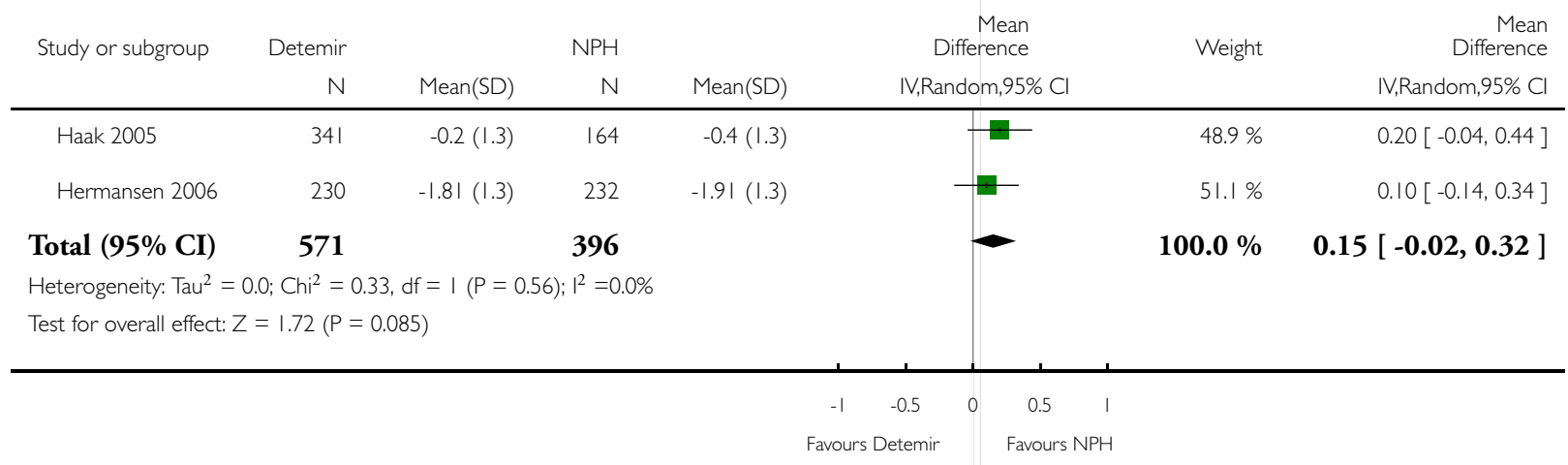


ADDITIONAL TABLES

Table 1. Definition of hypoglycaemia in study or as reported

\begin{tabular}{|c|c|c|c|c|c|c|c|c|c|}
\hline $\begin{array}{l}\text { Hypogly- } \\
\text { caemia }\end{array}$ & $\begin{array}{l}\text { Eliasche- } \\
\text { witz } \\
2006\end{array}$ & $\begin{array}{l}\text { Fritsche, } \\
2003\end{array}$ & $\begin{array}{l}\text { Haak, } \\
2005\end{array}$ & $\begin{array}{l}\text { Her- } \\
\text { mansen } \\
2006\end{array}$ & $\begin{array}{l}\text { Massi, } \\
2003\end{array}$ & $\begin{array}{l}\text { Riddle, } \\
2003\end{array}$ & $\begin{array}{l}\text { Rosen- } \\
\text { stock, } \\
2001\end{array}$ & $\begin{array}{l}\text { Yki- } \\
\text { Järvinen } \\
2006\end{array}$ & Bias \\
\hline severe & $\begin{array}{l}\text { require- } \\
\text { ment of as- } \\
\text { sis- } \\
\text { tance from } \\
\text { another } \\
\text { person and } \\
\text { blood glu- } \\
\text { cose }<2.8 \\
\text { mmol/L or } \\
\text { prompt re- } \\
\text { covery af- } \\
\text { ter oral car- } \\
\text { bohydrate, } \\
\text { i.v. glucose } \\
\text { or } \\
\text { glucagon } \\
\text { adminis- } \\
\text { tration }\end{array}$ & $\begin{array}{l}\text { symp- } \\
\text { toms and } \\
\text { require- } \\
\text { ment of as- } \\
\text { sis- } \\
\text { tance from } \\
\text { another } \\
\text { person and } \\
\text { blood glu- } \\
\text { cose < } 2.8 \\
\text { mmol/L or } \\
\text { prompt re- } \\
\text { covery af- } \\
\text { ter oral car- } \\
\text { bohydrate, } \\
\text { i.v. glucose } \\
\text { or } \\
\text { glucagon } \\
\text { adminis- } \\
\text { tration }\end{array}$ & $\begin{array}{l}\text { require- } \\
\text { ment of as- } \\
\text { sis- } \\
\text { tance from } \\
\text { another } \\
\text { person }\end{array}$ & $\begin{array}{l}\text { require- } \\
\text { ment of as- } \\
\text { sis- } \\
\text { tance from } \\
\text { another } \\
\text { person }\end{array}$ & $\begin{array}{l}\text { symp- } \\
\text { toms and } \\
\text { require- } \\
\text { ment of as- } \\
\text { sis- } \\
\text { tance from } \\
\text { another } \\
\text { person and } \\
\text { blood glu- } \\
\text { cose < } 2.8 \\
\text { mmol/L or } \\
\text { prompt re- } \\
\text { covery af- } \\
\text { ter oral car- } \\
\text { bohydrate, } \\
\text { i.v. glucose } \\
\text { or } \\
\text { glucagon } \\
\text { adminis- } \\
\text { tration }\end{array}$ & $\begin{array}{l}\text { symp- } \\
\text { toms and } \\
\text { require- } \\
\text { ment of as- } \\
\text { sis- } \\
\text { tance from } \\
\text { another } \\
\text { person and } \\
\text { blood glu- } \\
\text { cose < } 3.1 \\
\text { mmol/L or } \\
\text { prompt re- } \\
\text { covery af- } \\
\text { ter oral car- } \\
\text { bohydrate, } \\
\text { i.v. glucose } \\
\text { or } \\
\text { glucagon } \\
\text { adminis- } \\
\text { tration }\end{array}$ & $\begin{array}{l}\text { symp- } \\
\text { toms and } \\
\text { require- } \\
\text { ment of as- } \\
\text { sis- } \\
\text { tance from } \\
\text { another } \\
\text { person and } \\
\text { blood glu- } \\
\text { cose < } 2.0 \\
\text { mmol/L or } \\
\text { prompt re- } \\
\text { covery af- } \\
\text { ter oral car- } \\
\text { bohydrate, } \\
\text { i.v. glucose } \\
\text { or } \\
\text { glucagon } \\
\text { adminis- } \\
\text { tration }\end{array}$ & $\begin{array}{l}\text { symp- } \\
\text { toms and } \\
\text { require- } \\
\text { ment of as- } \\
\text { sis- } \\
\text { tance from } \\
\text { another } \\
\text { person and } \\
\text { blood glu- } \\
\text { cose < } 3.1 \\
\text { mmol/L or } \\
\text { prompt re- } \\
\text { covery af- } \\
\text { ter oral car- } \\
\text { bohydrate, } \\
\text { i.v. glucose } \\
\text { or } \\
\text { glucagon } \\
\text { adminis- } \\
\text { tration }\end{array}$ & possible \\
\hline $\begin{array}{l}\text { symp- } \\
\text { tomatic }\end{array}$ & $\begin{array}{l}\text { symptoms } \\
\text { or } \\
\text { blood glu- } \\
\text { cose mea- } \\
\text { surement } \\
\text { or both }\end{array}$ & $\begin{array}{l}\text { symptoms } \\
\text { or } \\
\text { blood glu- } \\
\text { cose mea- } \\
\text { surement } \\
\text { or both }\end{array}$ & - & - & $\begin{array}{l}\text { symptoms } \\
\text { or } \\
\text { blood glu- } \\
\text { cose mea- } \\
\text { surement } \\
\text { or both }\end{array}$ & $\begin{array}{l}\text { symptoms } \\
\text { or } \\
\text { blood glu- } \\
\text { cose mea- } \\
\text { surement } \\
\text { or both }\end{array}$ & $\begin{array}{l}\text { symptoms } \\
\text { or } \\
\text { blood glu- } \\
\text { cose mea- } \\
\text { surement } \\
\text { or both }\end{array}$ & $\begin{array}{l}\text { symptoms } \\
\text { or } \\
\text { blood glu- } \\
\text { cose mea- } \\
\text { surement } \\
\text { or both }\end{array}$ & possible \\
\hline overall & - & - & $\begin{array}{l}\text { symptoms } \\
\text { or } \\
\text { blood glu- } \\
\text { cose mea- } \\
\text { surement } \\
\text { or } \\
\text { blood glu- } \\
\text { cose }<2.8 \\
\mathrm{mmol} / \mathrm{L} \text { or } \\
\text { both }\end{array}$ & & - & - & - & - & $\begin{array}{l}\text { possible / } \\
\text { unclear }\end{array}$ \\
\hline nocturnal & $\begin{array}{l}\text { while } \\
\text { asleep be- } \\
\text { tween bed- } \\
\text { time } \\
\text { and getting }\end{array}$ & $\begin{array}{l}\text { while } \\
\text { asleep, be- } \\
\text { tween bed- } \\
\text { time after } \\
\text { the }\end{array}$ & $\begin{array}{l}\text { 23:00 - 06: } \\
00\end{array}$ & $\begin{array}{l}\text { 23:00 - 06: } \\
00\end{array}$ & $\begin{array}{l}\text { while } \\
\text { asleep, be- } \\
\text { tween the } \\
\text { in- } \\
\text { sulin injec- }\end{array}$ & $\begin{array}{l}\text { between } \\
\text { the in- } \\
\text { sulin injec- } \\
\text { tion in the } \\
\text { evening }\end{array}$ & $\begin{array}{l}\text { while } \\
\text { asleep, be- } \\
\text { tween the } \\
\text { in- } \\
\text { sulin injec- }\end{array}$ & - & possible \\
\hline
\end{tabular}




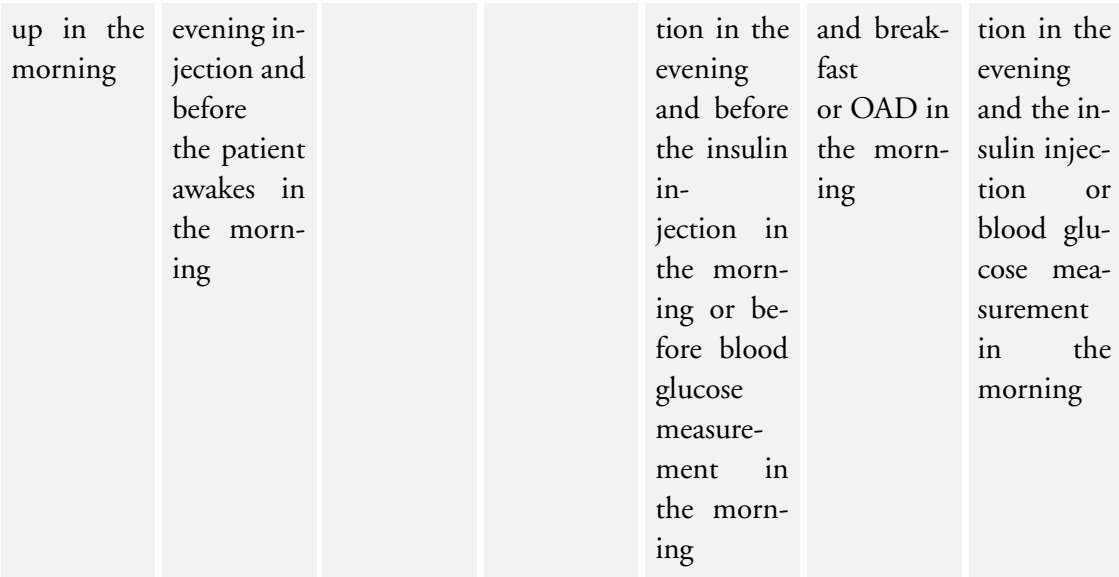

Notes

OAD: oral antidiabetic drugs

\section{A P P E N D I C ES}

\section{Appendix I. Search strategy}

\section{Search terms}

Unless otherwise stated, search terms are free text terms; $\mathrm{MeSH}=$ Medical subject heading (Medline medical index term); exp = exploded $\mathrm{MeSH}$; the dollar sign (\$) stands for any character(s); the question mark (?) = to substitute for one or no characters; tw = text word; $\mathrm{pt}=$ publication type; $\mathrm{sh}=\mathrm{MeSH}$; adj = adjacent

1. glargin\$.ti,ab,ot,tn,sh.

2. (Gly $\$ A 21$ or A21Gly\$ or (gly\$ adj1 A21)).ti,ab,ot.

3. $(\operatorname{Arg} \$ B 31$ or $B 31 \operatorname{Arg} \$$ or $(\arg \$ \operatorname{adj} 1 \mathrm{~B} 31))$.ti,ab,ot.

4. $(\operatorname{Arg} \$ B 32$ or B32Arg\$ or $(\arg \$$ adj1 B32)).ti,ab,ot.

5. (HOE-901 or HOE901).ti,ab,ot,tn.

6. Lantus\$.ti,ab,ot,tn.

7. (glargin $\$$ or 160337-95-1).rn.

8.1 or 2 or 3 or 4 or 5 or 6 or 7

9. detemir\$.ti,ab,ot,tn,sh.

10. (Lys\$B29 or B29Lys\$ or (lys\$ adj1 B29)).ti,ab,ot.

11. (Ala $\$ B 30$ or B30Ala $\$$ or (ala $\$$ adj1 B30)).ti,ab,ot.

12. (NN-304 or NN304).ti,ab,ot,tn.

13. Levemir\$.ti,ab,ot,tn. 


\section{(Continued)}

14. (detemir\$ or $169148-63-4$ or 201305-44-4 or 270588-25-5).rn.

15.9 or 10 or 11 or 12 or 13 or 14

16. 8 or 15

17. (insulin\$ adj6 (analog\$ or derivat\$)).ti,ab,ot.

18. (longacting adj6 insulin\$).ti,ab,ot.

19. ((long\$ or delayed\$ or slow\$ or ultralong\$) adj1 (acting or action) adj6 insulin\$).ti,ab,ot.

20. ((novel or new) adj6 insulin\$).ti,ab,ot.

21. 17 or 18 or 19 or 20

22. exp insulin/aa

23. exp Insulin Derivative/

24. 22 or 23

25. 21 or 24

26. exp Diabetes Mellitus/

27. diabet\$.ti,ab,ot.

28. mellitu\$.ti,ab,ot.

29. IDDM.ti,ab,ot.

30. MODY.ti,ab,ot.

31. NIDDM.ti,ab,ot.

32. (T1DM or T2DM or ((T1 or T2) adj1 DM)).ti,ab,ot.

33. (insulin\$ depend\$ or insulin?depend\$ or noninsulin\$ or noninsulin?depend\$).ti,ab,ot.

34. ((matury or late) adj onset\$ adj6 diabet\$).ti,ab,ot.

35. (typ\$ adj6 diabet\$).ti,ab,ot.

36.28 or 29 or 30 or 31 or 32 or 33 or 34 or 35

37. exp Diabetes Insipidus/

38. insipid\$.ti,ab,ot.

39.37 or 38

40.26 or 36

41.40 or $(27 \operatorname{not}(39 \operatorname{not} 40))$

42. controlled clinical trial.pt.

43. controlled clinical trials/

44. randomized controlled trial.pt.

45. randomized controlled trials/

46. random allocation/

47. cross-over studies/

48. double-blind method/

49. single-blind method/

50.42 or 43 or 44 or 45 or 46 or 47 or 48 or 49

51. ((singl\$ or doubl\$ or trebl\$ or tripl\$) adj6 (blind\$ or mask\$)).ti,ab,ot.

52. ((random\$ or cross-over or crossover) adj25 (trial\$ or study or studies or intervention\$ or investigat\$ or experiment $\$$ or design\$ or method $\$$ or group\$ or evaluation or evidenc\$ or data or test $\$$ or condition\$)).ti,ab,ot.

53. (random $\$$ adj25 (cross over or crossover)).ti,ab,ot.

54.51 or 52 or 53

55.50 or 54

56. exp meta-analysis/

57. meta analysis.pt.

58. (metaanaly\$ or meta analy\$).ti,ab,ot.

59.56 or 57 or 58

60. exp biomedical technology assessment/

61. hta.ti,ab,ot. 


\section{(Continued)}

62. ((biomed\$ or health\$) adj6 technolog\$ adj6 assessment\$).ti,ab,ot.

63. 60 or 61 or 62

64. exp "Review Literature"।

65. ((review\$ or search\$) adj25 (medical databas\$ or medline or pubmed or embase or cochrane or systemat\$)).ti,ab,ot.

66. 64 or 65

67. addresses.pt.

68. bibliography.pt.

69. biography.pt.

70. "case reports".pt.

71. "clinical conference”.pt.

72. comment.pt.

73. "conference abstract".pt.

74. "conference paper".pt.

75. congresses.pt.

76. “consensus development conference nih".pt.

77. "consensus development conference".pt.

78. dictionary.pt.

79. directory.pt.

80. editorial.pt.

81. festschrift.pt.

82. "historical article".pt.

83. interview.pt.

84. lectures.pt.

85. "legal cases".pt.

86. legislation.pt.

87. letter.pt.

88. "newspaper article".pt.

89. note.pt.

90. "patient education handout".pt.

91. "periodical index".pt.

92. "review of reported cases".pt.

93. "technical report".pt.

94. or/67-93

95. exp Animals/

96. exp animal/

97. exp animals/

98. “animal experiment".sh.

99. or/95-98

100. exp Humans/

101. exp human/

102. 100 or 101

103. 99 not 102

104. cn\$.an.

105. (16 or 25$)$ and 41

106. 55 not (94 or 103)

107.59 or 63 or 66

108. 105 and (106 or 104$)$

109. 105 and 107 
There were no language restrictions.

Appendix 2. Baseline characteristics

\begin{tabular}{|c|c|c|c|c|c|c|c|c|c|}
\hline $\begin{array}{l}\text { Charac- } \\
\text { teristic }\end{array}$ & $\begin{array}{l}\text { Eliasche- } \\
\text { witz } \\
2006\end{array}$ & $\begin{array}{l}\text { Fritsche } \\
2003\end{array}$ & $\begin{array}{l}\text { Haak } \\
2005\end{array}$ & $\begin{array}{l}\text { Her- } \\
\text { mansen } \\
2006\end{array}$ & $\begin{array}{l}\text { Massi } \\
2003\end{array}$ & $\begin{array}{l}\text { Riddle } \\
2003\end{array}$ & $\begin{array}{l}\text { Rosen- } \\
\text { stock } \\
2001\end{array}$ & $\begin{array}{l}\text { Yki- } \\
\text { Järvinen } \\
2006\end{array}$ & $\begin{array}{l}\text { Yokoyama } \\
2006\end{array}$ \\
\hline $\begin{array}{l}\text { Inter- } \\
\text { vention } 1 \\
\text { (I1) Inter- } \\
\text { vention } 2 \\
\text { (I2) Con- } \\
\text { trol } 1 \text { (C1) }\end{array}$ & $\begin{array}{l}\text { I1: subcu- } \\
\text { taneous } 1 \\
\mathrm{x} \text { glargine } \\
\text { at bedtime } \\
\text { plus } 4 \\
\mathrm{mg} / \text { day } \\
\text { glimepiride } \\
\text { in the } \\
\text { morning } \\
\mathrm{C} 1 \text { : sub- } \\
\text { cutaneous } \\
1 \mathrm{x} \text { NPH } \\
\text { at bedtime } \\
\text { plus } 4 \\
\text { mg/day } \\
\text { glimepiride } \\
\text { in the } \\
\text { morning }\end{array}$ & $\begin{array}{l}\text { I1: } \\
\text { glargine } \\
\text { in the } \\
\text { morning } \\
+3 \mathrm{mg} \\
\text { glimepiride } \\
\text { I2: } \\
\text { glargine at } \\
\text { bedtime } \\
+3 \text { mg } \\
\text { glimepiride } \\
\text { C1: NPH } \\
\text { at bedtime } \\
+3 \text { mg } \\
\text { glimepiride }\end{array}$ & $\begin{array}{l}\text { I1: detemir } \\
\text { once daily } \\
\text { subcuta- } \\
\text { neously } \\
\text { at bedtime } \\
\text { or detemir } \\
\text { twice daily } \\
\text { in } \\
\text { the morn- } \\
\text { ing and } \\
\text { at bedtime } \\
+ \text { mealtime } \\
\text { insulin as- } \\
\text { part } \\
\text { C1: NPH } \\
\text { once daily } \\
\text { subcuta- } \\
\text { neously at } \\
\text { bedtime or } \\
\text { NPH } \\
\text { twice daily } \\
\text { in } \\
\text { the morn- } \\
\text { ing and } \\
\text { at bedtime } \\
+ \text { mealtime } \\
\text { insulin as- } \\
\text { part }\end{array}$ & $\begin{array}{l}\text { I1: detemir } \\
\text { in the } \\
\text { morning } \\
\text { and in the } \\
\text { evening } \\
\text { (within } 1 \mathrm{~h} \\
\text { before din- } \\
\text { ner } \\
\text { until bed- } \\
\text { time) plus } \\
\text { OADs (not } \\
\text { titrated) } \\
\text { C1: NPH } \\
\text { in the } \\
\text { morning } \\
\text { and in the } \\
\text { evening } \\
\text { (within } 1 \mathrm{~h} \\
\text { before din- } \\
\text { ner } \\
\text { until bed- } \\
\text { time) plus } \\
\text { OADs (not } \\
\text { titrated) }\end{array}$ & $\begin{array}{l}\text { I1: } \\
\text { glargine } \\
\text { once daily } \\
\text { subcuta- } \\
\text { neously at } \\
\text { bed- } \\
\text { time + pre- } \\
\text { vious oral } \\
\text { antihyper- } \\
\text { glycaemic } \\
\text { agents } \\
\text { continued } \\
\text { C1: NPH } \\
\text { once daily } \\
\text { subcuta- } \\
\text { neously at } \\
\text { bed- } \\
\text { time + pre- } \\
\text { vious oral } \\
\text { antihyper- } \\
\text { glycaemic } \\
\text { agents } \\
\text { continued }\end{array}$ & $\begin{array}{l}\text { I1: sub- } \\
\text { cutaneous } \\
\text { glargine } \\
\text { once at } \\
\text { bedtime } \\
\text { plus oral } \\
\text { antihyper- } \\
\text { glycaemic } \\
\text { agents } \\
\text { (one or } \\
\text { two of } \\
\text { SU, met- } \\
\text { formin, } \\
\text { glitazones) } \\
\text { continued } \\
\text { at prestudy } \\
\text { dosages } \\
\text { C1: sub- } \\
\text { cutaneous } \\
\text { NPH once } \\
\text { at bedtime } \\
\text { plus oral } \\
\text { antihyper- } \\
\text { glycaemic } \\
\text { agents } \\
\text { (one or } \\
\text { two of } \\
\text { SU, met- } \\
\text { formin, } \\
\text { glitazones) } \\
\text { continued } \\
\text { at prestudy } \\
\text { dosages }\end{array}$ & $\begin{array}{l}\text { I1: } \\
\text { glargine } \\
\text { once daily } \\
\text { subcuta- } \\
\text { neously at } \\
\text { bed- } \\
\text { time + pre- } \\
\text { meal regu- } \\
\text { lar insulin } \\
\text { C1: NPH } \\
\text { once at } \\
\text { bedtime or } \\
\text { twice daily } \\
\text { in } \\
\text { the morn- } \\
\text { ing and } \\
\text { at bedtime } \\
\text { subcuta- } \\
\text { neously } \\
+ \text { premeal } \\
\text { regular in- } \\
\text { sulin }\end{array}$ & $\begin{array}{l}\text { I1: } \\
\text { glargine } \\
\text { once } \\
\text { at bedtime } \\
\text { plus met- } \\
\text { formin } \\
\mathrm{C} 1 \text { : } \\
\mathrm{NPH} \text { once } \\
\text { at bedtime } \\
\text { plus met- } \\
\text { formin }\end{array}$ & $\begin{array}{l}\text { I1: } \\
\text { glargine in } \\
\text { the morn- } \\
\text { ing plus as- } \\
\text { part } \\
\text { / lispro at } \\
\text { each } \\
\text { meal with } \\
\text { or without } \\
\text { OADs } \\
\text { C1: NPH } \\
\text { at bedtime } \\
\text { plus aspart } \\
\text { / lispro at } \\
\text { each } \\
\text { meal with } \\
\text { or without } \\
\text { OADs }\end{array}$ \\
\hline $\begin{array}{l}{[\mathrm{n}](\mathrm{I} 1 / \mathrm{I} 2 /} \\
\mathrm{C} 1 / \text { total })\end{array}$ & $\begin{array}{l}\text { I1: } 231 \\
\mathrm{C} 1: 250\end{array}$ & $\begin{array}{l}\text { I1: } 237 \\
\text { I2: } 229 \\
\text { C1: } 234 \\
\text { total: } 700\end{array}$ & $\begin{array}{l}\mathrm{I} 1: 341 \\
\mathrm{C} 1: 164 \\
\text { total: } 505\end{array}$ & $\begin{array}{l}\text { I1: } 237 \\
\text { C1: } 238\end{array}$ & $\begin{array}{l}\text { I1: } 293 \\
\text { C1:285 } \\
\text { Total: } 578\end{array}$ & $\begin{array}{l}\text { I1: } 372 \\
\text { C1: } 392 \\
\text { Total: } 764\end{array}$ & $\begin{array}{l}\text { I1: } 259 \\
\text { C1: } 259 \\
\text { Total: } 518\end{array}$ & $\begin{array}{l}\text { I1: } 61 \\
\mathrm{C} 1: 49\end{array}$ & $\begin{array}{l}\text { I1: } 31 \\
\text { C1: } 31\end{array}$ \\
\hline
\end{tabular}




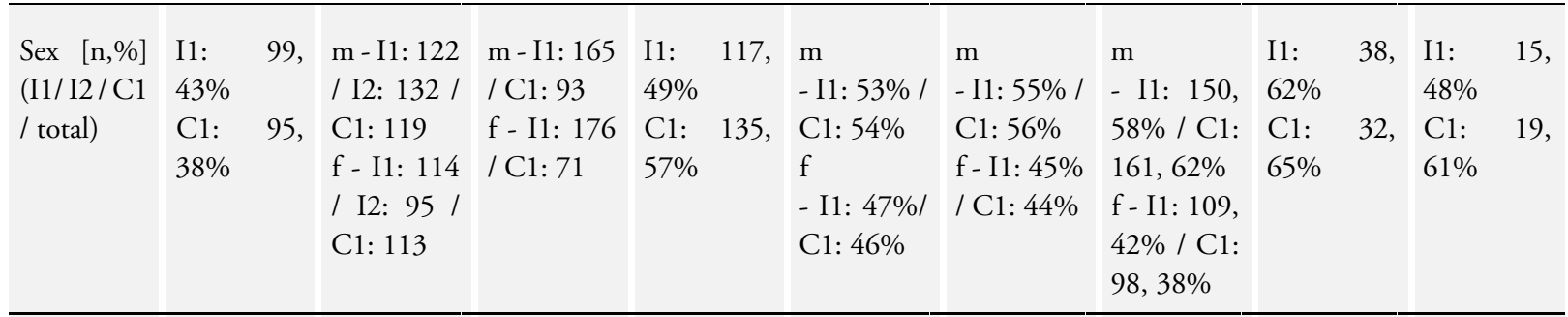

\begin{tabular}{|c|c|c|c|c|c|c|c|c|c|}
\hline Age, $\quad y$ & I1: $56(10)$ & I1: 61 (9) & I1: 61 (8. & I1: 61 (9) & I1: 60 (9. & I1: 55 (9. & I1: 60 (9. & I1: 56 (1 & I1: 61 (13) \\
\hline [mean, & C: 57 (10) & I2: 60 (9) & & C1: 60 (9) & & & & SE) & C1: $\quad 62$ \\
\hline $\begin{array}{l}\mathrm{SD}](\mathrm{I} 1 / \mathrm{I} 2 \\
/ \mathrm{C} 1 / \text { total })\end{array}$ & & $\begin{array}{l}\mathrm{C} 1: 62(9) \\
\text { total: } \mathrm{nr}\end{array}$ & $\begin{array}{l}\mathrm{C} 1: 60(8 . \\
\text { 4) } \\
\text { total: } \mathrm{nr}\end{array}$ & & $\begin{array}{l}\text { C1: } 59(9 . \\
\text { 1) } \\
\text { total: } \quad 60 \\
(9.2)\end{array}$ & $\begin{array}{l}\mathrm{C} 1: 56(8 . \\
9) \\
\text { total: } \mathrm{nr}\end{array}$ & $\begin{array}{l}\text { C1: } 59 \text { (9. } \\
\text { 9) } \\
\text { total: nr }\end{array}$ & $\begin{array}{l}\text { C1: } 57 \text { (1 } \\
\text { SE) }\end{array}$ & (10) \\
\hline
\end{tabular}

\begin{tabular}{|c|c|c|c|c|c|c|c|c|c|}
\hline $\begin{array}{l}\text { Eth- } \\
\text { nic groups } \\
\text { (I1/ I2 / C1 } \\
\text { / total) }\end{array}$ & 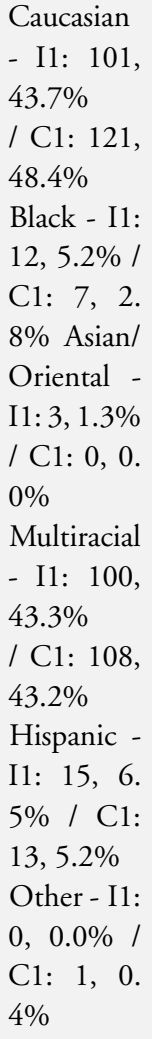 & $\mathrm{nr}$ & $\begin{array}{l}\text { Cau- } \\
\text { casian - I1: } \\
338 \text { / C1: } \\
\text { 162 Asian- } \\
\text { I1: } 3 \text { / C1: } \\
2\end{array}$ & $\begin{array}{l}\text { White - I1: } \\
232, \quad 97 . \\
8 \% \text { / C1: } \\
237, \quad 99 . \\
6 \% \text { Black - } \\
\text { I1: 1, } 0.4 \% \\
\text { / C1: } 0,0 . \\
0 \% \\
\text { Asian - I1: } \\
4,1.7 \% \text { / } \\
\text { C1: } 0,0 . \\
0 \% \\
\text { Other - I1: } \\
0,0.0 \% \quad / \\
\text { C1: } 1,0 . \\
4 \%\end{array}$ & $\mathrm{nr}$ & $\begin{array}{l}\text { Caucasian } \\
\text { - I1: 84\% / } \\
\text { C1: } 83 \% \\
\text { Black - I1: } \\
\text { 11\% / C1: } \\
\text { 13\% } \\
\text { Asian - I1: } \\
3 \% \text { / C1: } \\
3 \% \\
\text { Multiracial } \\
\text { - I1: } 1 \% \text { / } \\
\text { C1: 1\% } \\
\text { Hispanic } \\
\text { heritage: } \\
\text { I1: } 10 \% \text { / } \\
\text { C1: } 6 \%\end{array}$ & $\begin{array}{l}\text { Caucasian } \\
\text { - I1: 208, } \\
\text { 81\% / C1: } \\
\text { 209, 81\% } \\
\text { Black - I1: } \\
40,16 \% \text { / } \\
\text { C1: 36, } \\
\text { 14\% His- } \\
\text { panic: } \\
\text { I1: 22, 9\% } \\
\text { / C1: 22, } \\
9 \%\end{array}$ & $\mathrm{nr}$ & $\mathrm{nr}$ \\
\hline
\end{tabular}

\begin{tabular}{|c|c|c|c|c|c|c|c|c|c|}
\hline $\begin{array}{l}\text { Duration } \\
\text { of disease, } \\
\text { y [mean, } \\
\text { SD] (I1/ I2 } \\
\text { / C1 / total) }\end{array}$ & $\begin{array}{l}\text { I1: } 10 \quad(6 . \\
4) \\
\text { C1: } 11(6 . \\
4)\end{array}$ & $\begin{array}{l}\text { I1: } 9 \quad(0- \\
38) \\
\text { [range] } \\
\text { I2: } 8 \quad(1- \\
51) \\
\text { [range] } \\
\text { C1: } 9(1-\end{array}$ & $\begin{array}{l}\text { I1: } 13(7 . \\
4) \\
\text { C1: } 14(8 . \\
0)\end{array}$ & $\begin{array}{l}\text { I1: } 10 \quad(6 . \\
6) \\
\text { C1: } 10(6 . \\
2)\end{array}$ & $\begin{array}{l}\text { I1: } 10 \quad(6 . \\
2) \\
\text { C1: } 11(6 . \\
0)\end{array}$ & $\begin{array}{l}\text { I1: } 8 \text { (5.6) } \\
\text { C1: } 9(5.6)\end{array}$ & $\begin{array}{l}\text { I1: } 13 \text { (8. } \\
\text { 3) } \\
\text { C1: } 14 \text { (9. } \\
0)\end{array}$ & $\begin{array}{lll}\text { I1: } & 9 & (1 \\
\text { SE) } & & \\
\text { C1: } & 9 & (1 \\
\text { SE) } & & \end{array}$ & $\begin{array}{l}\text { I1: } 14(10) \\
\text { C1: } 12 \text { (9) }\end{array}$ \\
\hline
\end{tabular}


39) [range]

\begin{tabular}{|c|c|c|c|c|c|c|c|c|c|}
\hline $\begin{array}{l}\text { Body mass } \\
\text { index, kg/ } \\
\mathrm{m}^{2} \text { [mean, } \\
\mathrm{SD}](\mathrm{I} 1 / \mathrm{I} 2 \\
/ \mathrm{C} 1 / \text { to- } \\
\text { tal) }\end{array}$ & $\begin{array}{l}\mathrm{I} 1: 27.3(3 . \\
7) \\
\mathrm{C} 1: \quad 27.2 \\
(4.0)\end{array}$ & $\begin{array}{l}\text { I1: } 28.6(4 . \\
5) \\
\text { I2: } 28.7(3 . \\
9) \\
\text { C1: } 28.9 \\
(3.9)\end{array}$ & $\begin{array}{l}\mathrm{I} 1: 30.1(5 . \\
0) \\
\mathrm{C} 1: \quad 31.1 \\
(5.8)\end{array}$ & $\begin{array}{l}\text { I1: } 28.9(3 . \\
6) \\
\text { C1: } 29.0 \\
(3.6)\end{array}$ & $\begin{array}{l}\text { I1: } 29.3(4 . \\
3) \\
\text { C1: } 28.8 \\
\text { (4.3) } \\
\text { Total: } 29.1 \\
(4.3)\end{array}$ & $\begin{array}{l}\text { I1: } 32.5(4 . \\
6) \\
\text { C1: } 32.2 \\
(4.8)\end{array}$ & $\begin{array}{l}\mathrm{I} 1: 30.7(5 . \\
0) \\
\mathrm{C} 1: \quad 30.4 \\
(5.1)\end{array}$ & $\begin{array}{l}\mathrm{I} 1: 31.3(0 . \\
7 \mathrm{SE}) \\
\mathrm{C} 1: \quad 32.0 \\
(0.8 \mathrm{SE})\end{array}$ & $\begin{array}{l}\text { I1: } 26.4 \text { (4. } \\
5) \\
\text { C1: } 26.1 \\
(3.2)\end{array}$ \\
\hline $\begin{array}{l}\text { Pharmaco- } \\
\text { naive } \\
\text { patients [n, } \\
\% \text { ] (I1/ I2 / } \\
\text { C1 / total) }\end{array}$ & $\begin{array}{l}\text { I1: } 0,0 \% \\
\text { C1: } 0,0 \%\end{array}$ & $\begin{array}{l}\text { I1: } 0 \% \text { I2: } \\
0 \% \\
\text { C1: } 0 \% \\
\text { total: } 0 \%\end{array}$ & $\begin{array}{l}\mathrm{I} 1: 0 \% \\
\mathrm{C} 1: 0 \% \\
\text { total: } 0 \%\end{array}$ & $\begin{array}{l}\text { I1: } 0,0 \% \\
\text { C1: } 0,0 \%\end{array}$ & $\begin{array}{l}\text { I1: ? } \\
\text { C1: ? } \\
\text { total: } 0.2 \%\end{array}$ & $\begin{array}{l}\mathrm{I} 1: 0 \% \\
\mathrm{C} 1: 0 \% \\
\text { total: } 0 \%\end{array}$ & $\begin{array}{l}\text { I1: } 0 \% \\
\text { C1: } 0 \% \\
\text { Total: } 0 \%\end{array}$ & $\begin{array}{l}\text { I1: } 0,0 \% \\
\text { C1: } 0,0 \%\end{array}$ & $\begin{array}{l}\text { I1: } 0,0 \% \\
\text { C1: } 0,0 \%\end{array}$ \\
\hline $\begin{array}{l}\text { Co-mor- } \\
\text { bidity (I1/ } \\
\text { I2 / C1 / } \\
\text { total) }\end{array}$ & $\begin{array}{l}\mathrm{I} 1: \mathrm{nr} \\
\mathrm{C} 1: \mathrm{nr}\end{array}$ & $\begin{array}{l}\text { CVD - I1: } \\
\text { nr / I2: nr } \\
\text { / C1: nr / } \\
\text { total: 64\% } \\
\text { diabetic } \\
\text { retinopa- } \\
\text { thy - I1: } \\
\text { nr / I2: nr } \\
\text { / C1: nr / } \\
\text { total: 19\% } \\
\text { neuropa- } \\
\text { thy - I1: } \\
\text { nr / I2: nr } \\
\text { / C1: nr / } \\
\text { total: } 24 \% \\
\text { nephropa- } \\
\text { thy - I1: nr } \\
\text { / I2: nr / } \\
\text { C1: nr / to- } \\
\text { tal: 6\% pe- } \\
\text { ripheral } \\
\text { macroan- } \\
\text { giopathy - } \\
\text { I1: nr / I2: } \\
\text { nr / C1: } \\
\text { nr / total: } \\
\text { 13\% }\end{array}$ & $\begin{array}{l}\mathrm{I} 1: \mathrm{nr} \\
\mathrm{C} 1: \mathrm{nr}\end{array}$ & $\begin{array}{l}\text { Total: hy- } \\
\text { perten- } \\
\text { sion }(69 \%) \\
\text { ischemic } \\
\text { heart dis- } \\
\text { ease }(14 \%)\end{array}$ & $\begin{array}{l}\text { diabetic } \\
\text { retinopa- } \\
\text { thy - I1: } \\
18 \% \text { / C1: } \\
16 \% \text { / to- } \\
\text { tal: nr neu- } \\
\text { ropathy } \\
\text { - I1: } 18 \% \\
\text { / C1: } 16 \% \\
\text { / total: nr } \\
\text { nephropa- } \\
\text { thy } \\
-\quad \mathrm{I} 1: 8 \% \\
\text { / C1: } 6 \% \\
\text { / total: nr } \\
\text { macroan- } \\
\text { giopathy - } \\
\text { I1: } 10 \% \text { / } \\
\text { C1: } 10 \% \text { / } \\
\text { total: nr }\end{array}$ & $\begin{array}{l}\mathrm{I1}: \mathrm{nr} \\
\mathrm{C} 1: \mathrm{nr}\end{array}$ & $\begin{array}{l}\text { retinopa- } \\
\text { thy - I1: } \\
124, \quad 48 \% \\
\text { / C1: } 147 \text {, } \\
57 \%\end{array}$ & $\begin{array}{l}\text { I1: ? } \\
\text { C1: ? }\end{array}$ & $\begin{array}{l}\text { I1: ? } \\
\text { C1: ? }\end{array}$ \\
\hline $\begin{array}{l}\text { Co-med- } \\
\text { ication (I1/ } \\
\text { I2 / C1 / } \\
\text { total) }\end{array}$ & $\begin{array}{l}\mathrm{I} 1: \mathrm{nr} \\
\mathrm{C} 1: \mathrm{nr}\end{array}$ & $\begin{array}{l}\text { ACE } \\
\text { inhibitors - } \\
\text { I1: nr / I2: } \\
\mathrm{nr} / \mathrm{C} 1: \\
\mathrm{nr} / \text { total: } \\
48 \% \text { lipid }\end{array}$ & $\begin{array}{l}\text { basal-bo- } \\
\text { lus insulin } \\
\text { - I1: } 86 \% \\
\text { / C1: } 88 \% \\
\text { bipha- } \\
\text { sic insulin- }\end{array}$ & $\begin{array}{l}\text { metformin } \\
\text { alone - I1: } \\
5.9 \% \text { / C1: } \\
8.0 \% \text { sec- } \\
\text { retagogue } \\
\text { alone - I1: }\end{array}$ & $\begin{array}{l}\text { Use } \\
\text { of OAD - } \\
75 \%: S U+ \\
\text { metformin } \\
\text { - I1: ? / } \\
\text { C1: ? / to- }\end{array}$ & $\begin{array}{l}\text { SU only - } \\
\text { I1 } 11 \% \\
\text { / C1: } 10 \% \\
\text { metformin } \\
\text { only - I1: } \\
8 \% \text { / } \mathrm{C} 1 \text { : }\end{array}$ & $\mathrm{nr}$ & $\begin{array}{l}\text { metformin } \\
\text { dose } \quad(\mathrm{g} / \\
\text { day })-\mathrm{I} 1 \text { : } \\
2.28(0.06 \\
\mathrm{SE}) \text { / } \mathrm{C} 1 \text { : } \\
2.19 \quad(0 .\end{array}$ & $\begin{array}{lr}\text { aspart } & - \\
\text { I1: } & 26,83 . \\
9 \% & / \\
27, & \text { C1: } \\
1 \% & \text { lispro } \\
\text { - I1: } & 5,16 .\end{array}$ \\
\hline
\end{tabular}




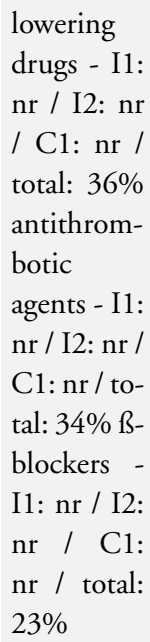

I1: 14
$12 \%$

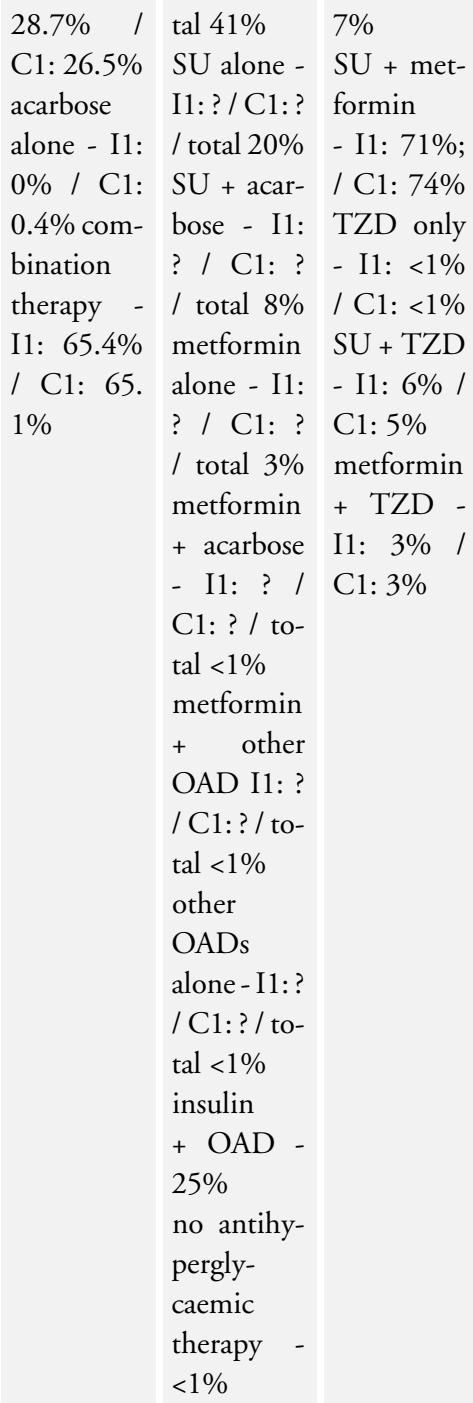

\begin{tabular}{|c|c|c|c|c|c|c|c|c|c|}
\hline $\begin{array}{l}\text { HbA1c } \\
\text { [mean, } \\
\text { SD] (I1/ I2 } \\
\text { / C1 / to- } \\
\text { tal) }\end{array}$ & $\begin{array}{l}\text { I1: } 9.1 \% \\
(1.0) \\
\text { C1: } 9.2 \% \\
(0.9)\end{array}$ & $\begin{array}{l}\text { I1: } 9.1 \text { (1. } \\
\text { 0)\% } \\
\text { I2: } 9.1 \text { (1. } \\
\text { 0)\% } \\
\text { C1: } 9.1(1 . \\
\text { 1)\% }\end{array}$ & $\begin{array}{l}\text { I1: } 7.9 \text { (1. } \\
\text { 3)\% } \\
\text { C1: } 7.8(1 . \\
3) \%\end{array}$ & $\begin{array}{l}\text { I1: } \quad 8.6 \% \\
(0.8) \\
\text { C1: } 8.5 \% \\
(0.8)\end{array}$ & $\begin{array}{l}\mathrm{I} 1: \quad 9.0 \% \\
(1.2) \\
\mathrm{C} 1: \quad 8.9 \% \\
(1.1) \\
\text { total: } 8.9 \% \\
(1.2)\end{array}$ & $\begin{array}{l}\text { I1: } \quad 8.6 \% \\
(0.9) \\
\text { C1: } 8.6 \% \\
(0.9)\end{array}$ & $\begin{array}{l}\text { I1: } \quad 8.6 \% \\
(1.2) \\
\text { C1: } 8.5 \% \\
(1.2)\end{array}$ & $\begin{array}{l}\text { I1: } \quad 9.5 \% \\
(0.1 \text { SE) } \\
\text { C1: } 9.6 \% \\
(0.1 \text { SE) }\end{array}$ & $\begin{array}{l}\text { I1: } 7.2 \%, \\
0.86 \\
\text { C1: } 6.9 \%, \\
0.72\end{array}$ \\
\hline $\begin{array}{l}\text { Notes } \\
\text { m: male } \\
\text { f: female } \\
\text { OAD(s): } \\
\text { oral antidi- } \\
\text { abetic } \\
\text { drugs }\end{array}$ & & & & & $\begin{array}{l}\text { Even } \\
\text { though } \\
\text { it was re- } \\
\text { quired for } \\
\text { patients to } \\
\text { be elegible }\end{array}$ & $\begin{array}{l}\text { baseline } \\
\text { charac- } \\
\text { teristics are } \\
\text { given } \\
\text { for I1: } 367 \\
\text { and } \mathrm{C} 1 \text { : }\end{array}$ & & & \\
\hline
\end{tabular}

$05 \mathrm{SE})$ sul- $1 \% \quad / \mathrm{C} 1$ : fonylurea $4, \quad 12.9 \%$ (\%) - I1: glimepiride 79\% / C1: - I1: 12, 86\% ACE 38.7\% / inhibitor $\mathrm{C} 1 \mathrm{:} \quad 14$, (\%) - I1: $45.2 \%$ $57 \%$ / C1: metformin $55 \%$ beta- - I1: 20, blocker or $64.5 \%$ / thi- $\quad$ C1: 19 , azide $(\%)$ - $61.3 \%$ I1: $71 \%$ / C1: $63 \%$ 


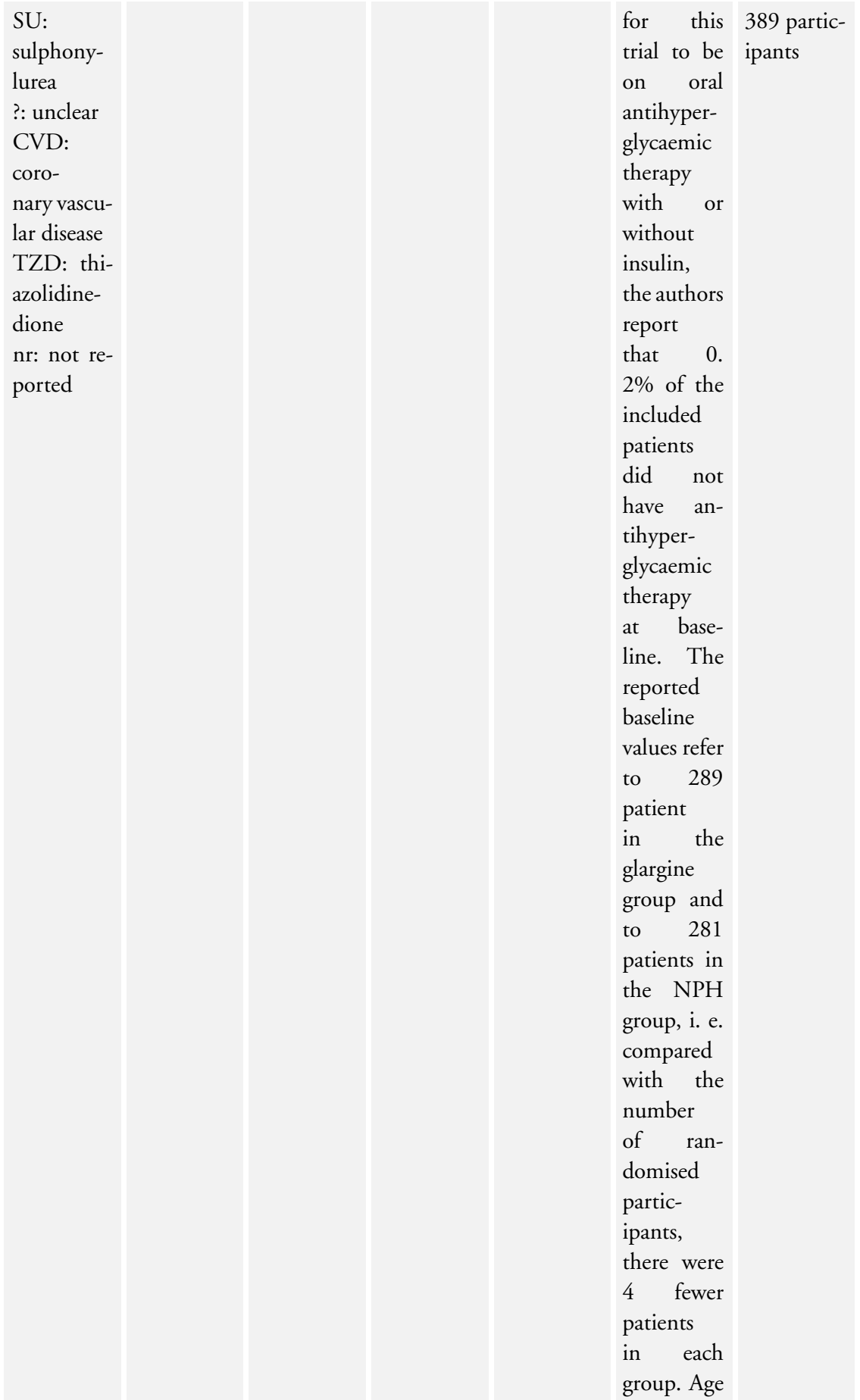




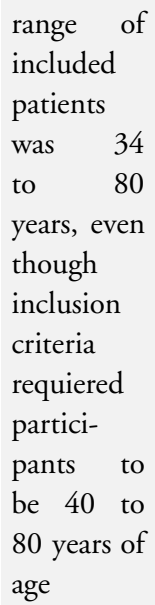

\section{Appendix 3. Adverse events}

events

\begin{tabular}{|c|c|c|c|c|c|c|c|c|c|}
\hline $\begin{array}{l}\text { Charac- } \\
\text { teristic }\end{array}$ & $\begin{array}{l}\text { Eliasche- } \\
\text { witz } \\
2006\end{array}$ & $\begin{array}{l}\text { Fritsche, } \\
2003\end{array}$ & $\begin{array}{l}\text { Haak, } \\
2005\end{array}$ & $\begin{array}{l}\text { Her- } \\
\text { mansen } \\
2006\end{array}$ & $\begin{array}{l}\text { Massi, } \\
2003\end{array}$ & $\begin{array}{l}\text { Riddle, } \\
2003\end{array}$ & $\begin{array}{l}\text { Rosen- } \\
\text { stock, } \\
2001\end{array}$ & $\begin{array}{l}\text { Yki- } \\
\text { Järvinen } \\
2006\end{array}$ & $\begin{array}{l}\text { Yokoyama } \\
2006\end{array}$ \\
\hline $\begin{array}{l}\text { Inter- } \\
\text { vention } 1 \\
\text { (I1) Inter- } \\
\text { vention } 2 \\
\text { (I2) Con- } \\
\text { trol } 1 \text { (C1) }\end{array}$ & $\begin{array}{l}\text { I1: } \\
\text { glargine } \\
\text { plus } \\
\text { glimepiride } \\
\text { C1: NPH } \\
\text { plus } \\
\text { glimepiride }\end{array}$ & $\begin{array}{l}\text { I1: } \\
\text { glargine } \\
\text { in the } \\
\text { morning } \\
+3 \mathrm{mg} \\
\text { glimepiride } \\
\text { I2: } \\
\text { glargine at } \\
\text { bedtime } \\
+3 \mathrm{mg} \\
\text { glimepiride } \\
\text { C1: NPH } \\
\text { at bedtime } \\
+3 \mathrm{mg} \\
\text { glimepiride }\end{array}$ & $\begin{array}{l}\text { I1: detemir } \\
\text { once daily } \\
\text { subcuta- } \\
\text { neously } \\
\text { at bedtime } \\
\text { or detemir } \\
\text { twice daily } \\
\text { in } \\
\text { the morn- } \\
\text { ing and } \\
\text { at bedtime } \\
+ \text { mealtime } \\
\text { insulin as- } \\
\text { part } \\
\text { C1: NPH } \\
\text { once daily } \\
\text { subcuta- } \\
\text { neously at } \\
\text { bedtime or } \\
\text { NPH }\end{array}$ & $\begin{array}{l}\text { I1: detemir } \\
\text { (twice } \\
\text { daily) plus } \\
\text { OAD } \\
\text { (met- } \\
\text { formin, in- } \\
\text { sulin secre- } \\
\text { tagogues, } \\
\text { alpha-glu- } \\
\text { cosidase } \\
\text { inhibitors) } \\
\text { C1: NPH } \\
\text { (twice } \\
\text { daily) plus } \\
\text { OAD } \\
\text { (met- } \\
\text { formin, in- } \\
\text { sulin secre- } \\
\text { tagogues, } \\
\text { alpha-glu- }\end{array}$ & $\begin{array}{l}\text { I1: } \\
\text { glargine } \\
\text { once daily } \\
\text { subcuta- } \\
\text { neously at } \\
\text { bed- } \\
\text { time + pre- } \\
\text { vious oral } \\
\text { antihyper- } \\
\text { glycaemic } \\
\text { agents } \\
\text { continued } \\
\text { C1: NPH } \\
\text { once daily } \\
\text { subcuta- } \\
\text { neously at } \\
\text { bed- } \\
\text { time + pre- } \\
\text { vious oral }\end{array}$ & $\begin{array}{l}\text { I1: sub- } \\
\text { cutaneous } \\
\text { glargine } \\
\text { once at } \\
\text { bedtime } \\
\text { plus oral } \\
\text { antihyper- } \\
\text { glycaemic } \\
\text { agents } \\
\text { (one or } \\
\text { two of } \\
\text { SU, met- } \\
\text { formin, } \\
\text { glitazones) } \\
\text { continued } \\
\text { at prestudy } \\
\text { dosages } \\
\text { C1: sub- } \\
\text { cutaneous }\end{array}$ & $\begin{array}{l}\text { I1: } \\
\text { glargine } \\
\text { once daily } \\
\text { subcuta- } \\
\text { neously at } \\
\text { bed- } \\
\text { time + pre- } \\
\text { meal regu- } \\
\text { lar insulin } \\
\mathrm{C} 1 \text { : NPH } \\
\text { once at } \\
\text { bedtime or } \\
\text { twice daily } \\
\text { in } \\
\text { the morn- } \\
\text { ing and } \\
\text { at bedtime } \\
\text { subcuta- } \\
\text { neously }\end{array}$ & $\begin{array}{l}\text { I1: } \\
\text { glargine } \\
\text { once } \\
\text { at bedtime } \\
\text { plus met- } \\
\text { formin } \mathrm{C} 1 \text { : } \\
\mathrm{NPH} \text { once } \\
\text { at bedtime } \\
\text { plus met- } \\
\text { formin }\end{array}$ & $\begin{array}{l}\text { I1: } \\
\text { glargine in } \\
\text { the morn- } \\
\text { ing plus as- } \\
\text { part } \\
\text { / lispro at } \\
\text { each } \\
\text { meal with } \\
\text { or without } \\
\text { OADs C1: } \\
\text { NPH } \\
\text { at bedtime } \\
\text { plus aspart } \\
\text { / lispro at } \\
\text { each } \\
\text { meal with } \\
\text { or without } \\
\text { OADs }\end{array}$ \\
\hline
\end{tabular}




\begin{tabular}{|c|c|c|c|c|}
\hline $\begin{array}{l}\text { twice daily } \\
\text { in } \\
\text { the morn- } \\
\text { ing and } \\
\text { at bedtime } \\
+ \text { mealtime } \\
\text { insulin as- } \\
\text { part }\end{array}$ & $\begin{array}{l}\text { cosidase } \\
\text { inhibitors) }\end{array}$ & $\begin{array}{l}\text { antihyper- } \\
\text { glycaemic } \\
\text { agents } \\
\text { continued }\end{array}$ & $\begin{array}{l}\mathrm{NPH} \text { once } \\
\text { at bedtime } \\
\text { plus oral } \\
\text { antihyper- } \\
\text { glycaemic } \\
\text { agents } \\
\text { (one or } \\
\text { two of } \\
\text { SU, met- } \\
\text { formin, } \\
\text { glitazones) } \\
\text { continued } \\
\text { at prestudy } \\
\text { dosages }\end{array}$ & $\begin{array}{l}+ \text { premeal } \\
\text { regular in- } \\
\text { sulin }\end{array}$ \\
\hline
\end{tabular}

\begin{tabular}{|c|c|c|c|c|c|c|c|c|}
\hline $\begin{array}{l}\text { [n] of par- } \\
\text { ticipants } \\
\text { who died }\end{array}$ & $\begin{array}{l}\text { I1: } 0 \\
\text { C1: } 0\end{array}$ & $\begin{array}{l}\text { I1: } 0 \\
\text { I2: } 2 \\
\text { C1: } 1\end{array}$ & $\begin{array}{l}\text { I1: } 1 \\
\text { C1: } 0\end{array}$ & $\begin{array}{l}\text { I1: ? } \\
\text { C1: ? }\end{array}$ & $\begin{array}{l}\text { I1: } 1 \\
\text { C1: } 5 \text { or } 6 \\
\text { or } 7 \text { Total: } \\
7 \text { or } 8\end{array}$ & $\begin{array}{l}\text { I1: ? } \\
\text { C1: ? }\end{array}$ & $\begin{array}{l}\text { I1: ? } \\
\text { C1: ? }\end{array}$ & $\begin{array}{l}\text { I1: ? } \\
\text { C1: ? }\end{array}$ \\
\hline
\end{tabular}

\begin{tabular}{|c|c|c|c|c|c|c|c|c|c|}
\hline $\begin{array}{l}{[\mathrm{n}] \text { adverse }} \\
\text { events (I1/ } \\
\mathrm{I} 2 / \mathrm{C} 1 / \\
\text { total) }\end{array}$ & $\begin{array}{l}\text { I1: } 137 \\
\text { C1: } 150\end{array}$ & $\begin{array}{l}\text { I1: } 403 \\
\text { I2: } 414 \\
\text { C1: } 423 \\
\text { P ? ("simi- } \\
\text { lar") }\end{array}$ & $\begin{array}{l}\text { I1: } 213 \\
\text { [pa- } \\
\text { tients with } \\
\text { events] } \\
\text { C1: } 103 \\
\text { [pa- } \\
\text { tients with } \\
\text { events] }\end{array}$ & $\begin{array}{l}\text { I1: ? } \\
\text { C1: ? }\end{array}$ & $\begin{array}{l}\text { I1: } 185 \\
\text { [pa- } \\
\text { tients with } \\
\text { events] } \\
\text { C1: } 193 \\
\text { [pa- } \\
\text { tients with } \\
\text { events] } \\
\text { Total: } 378 \\
\text { [pa- } \\
\text { tients with } \\
\text { events] }\end{array}$ & $\mathrm{nr}$ & $\begin{array}{l}\text { treatment- } \\
\text { related ad- } \\
\text { verse } \\
\text { events - I1: } \\
27 / \mathrm{C} 1: 20 \\
\text { [pa- } \\
\text { tients with } \\
\text { events] }\end{array}$ & $\begin{array}{l}\text { I1: } 33 \text { [pa- } \\
\text { tients with } \\
\text { events] } \\
\text { C1: } 24 \\
\text { [pa- } \\
\text { tients with } \\
\text { events] }\end{array}$ & $\begin{array}{l}\mathrm{I} 1: \text { ? } \\
\mathrm{C} 1: ?\end{array}$ \\
\hline $\begin{array}{l}{[\%]} \\
\text { adverse } \\
\text { events (I1/ } \\
\text { I2 / C1 / } \\
\text { total) }\end{array}$ & $\begin{array}{l}\text { I1: } \\
59 \% \text { [pa- } \\
\text { tients with } \\
\text { events] } \\
\mathrm{C} 1: \\
60 \% \text { [pa- } \\
\text { tients with } \\
\text { events] }\end{array}$ & $\mathrm{nr}$ & $\begin{array}{l}\text { I1: } \\
62 \% \text { [pa- } \\
\text { tients with } \\
\text { events] } \\
\text { C1: } \\
63 \% \text { [pa- } \\
\text { tients with } \\
\text { events] }\end{array}$ & $\begin{array}{l}\text { I1: ? } \\
\text { C1: ? }\end{array}$ & $\begin{array}{l}\text { adverse } \\
\text { events: I1: } \\
65 \% / \mathrm{C} 1: \\
69 \% \text { [pa- } \\
\text { tients with } \\
\text { events] } \\
\text { events po- } \\
\text { tentially } \\
\text { related to } \\
\text { study med- } \\
\text { ication: I1: } \\
5.5 \% \text { / C1: } \\
7.5 \% \text { [pa- } \\
\text { tients with } \\
\text { events] pa- }\end{array}$ & $\mathrm{nr}$ & $\begin{array}{l}\text { treatment- } \\
\text { related ad- } \\
\text { verse } \\
\text { events - I1: } \\
10 . \\
4 \% \text { / C1: } \\
7.7 \% \text { [pa- } \\
\text { tients with } \\
\text { events] }\end{array}$ & $\begin{array}{l}\text { I1: } \\
54 \% \text { [pa- } \\
\text { tients with } \\
\text { events] } \\
\text { C1: } \\
49 \% \text { [pa- } \\
\text { tients with } \\
\text { events] }\end{array}$ & $\begin{array}{l}\mathrm{I} 1: ? \\
\mathrm{C} 1: ?\end{array}$ \\
\hline
\end{tabular}




\begin{tabular}{|c|c|c|c|c|c|c|c|c|c|}
\hline & & & & & $\begin{array}{l}\text { tients with } \\
\text { in- } \\
\text { jection site } \\
\text { reactions: - } \\
\text { I1: } 3.1 \% \\
\text { / C1: } 3.9 \% \\
\text { [pa- } \\
\text { tients with } \\
\text { events] }\end{array}$ & & & & \\
\hline $\begin{array}{l}{[\mathrm{n}] \text { seri- }} \\
\text { ous adverse } \\
\text { events (I1/ } \\
\text { I2 / C1 / } \\
\text { total) }\end{array}$ & $\begin{array}{l}\text { I1: } 10 \\
\text { C1: } 10\end{array}$ & $\mathrm{nr}$ & $\begin{array}{l}\text { I1: } 22 \text { [pa- } \\
\text { tients with } \\
\text { events] } \\
\text { C1:16 [pa- } \\
\text { tients with } \\
\text { events] }\end{array}$ & $\begin{array}{l}\text { I1: ? } \\
\text { C1: ? }\end{array}$ & $?$ & $\mathrm{nr}$ & ? & $\begin{array}{l}\text { I1: } 1 \text { [pa- } \\
\text { tients with } \\
\text { events] } \\
\text { C1: } 4 \text { [pa- } \\
\text { tients with } \\
\text { events] }\end{array}$ & $\begin{array}{l}\text { I1: ? } \\
\mathrm{C} 1: ?\end{array}$ \\
\hline $\begin{array}{l}{[\%] \text { serious }} \\
\text { adverse } \\
\text { events (I1/ } \\
\text { I2 / C1 / } \\
\text { total) }\end{array}$ & $\begin{array}{l}\text { I1: } 4.3 \% \\
\text { C1: } 4.0 \%\end{array}$ & $\mathrm{nr}$ & $\begin{array}{l}\text { I1: } 6.5 \% \\
\text { C1: } 9.8 \%\end{array}$ & $\begin{array}{l}\text { I1: ? } \\
\text { C1: ? }\end{array}$ & $?$ & $\mathrm{nr}$ & ? & $\begin{array}{l}\text { I1: } \\
1.6 \% \text { [pa- } \\
\text { tients with } \\
\text { events] } \\
\text { C1: } \\
8.2 \% \text { [pa- } \\
\text { tients with } \\
\text { events] }\end{array}$ & $\begin{array}{l}\text { I1: ? } \\
\mathrm{C} 1: ?\end{array}$ \\
\hline $\begin{array}{l}\text { [n] drop- } \\
\text { outs due to } \\
\text { adverse } \\
\text { events (I1/ } \\
\text { I2 / C1 / } \\
\text { total) }\end{array}$ & $\begin{array}{l}\text { I1: } 2 \\
\text { C1: } 0 \text { total: } \\
2\end{array}$ & $\begin{array}{l}\text { hypogly- } \\
\text { caemic } \\
\text { events } \\
\text { - NA other } \\
\text { events } \\
\text { - NA over- } \\
\text { all events - } \\
\text { I1: 5/236 ; } \\
\text { I2: 4/227 ; } \\
\text { C1: } 7 / 232 \\
\text {; Total: } 16 / \\
695 \text {; P =? } \\
\text { (“similar") }\end{array}$ & $\begin{array}{l}\text { I1: } 8 \\
\text { C1: } 1 \\
\text { Total: } 9\end{array}$ & $\begin{array}{l}\text { I1: } 3 \\
\text { C1: } 4 \\
\text { Total: } 7\end{array}$ & $\begin{array}{l}\text { I1: } 5 \mathrm{C} 1: \\
\text { ? FDR re- } \\
\text { port - I1: } 5 \\
\text { / C1: } 7\end{array}$ & $\begin{array}{l}\text { hypogly- } \\
\text { caemic } \\
\text { events - I1: } \\
1 \\
\mathrm{C} 1: 3 \text { / To- } \\
\text { tal: } 4 \text { other } \\
\text { events - I1: } \\
6 \text { / C1:4 } \\
\text { / Total: } 10 \\
\text { over- } \\
\text { all events - } \\
\text { NA }\end{array}$ & $\begin{array}{l}\text { I1: } 9 \mathrm{C} 1: 7 \\
\text { total: } 16\end{array}$ & $\begin{array}{l}\text { I1: } 1 \\
\text { C1: } 1 \\
\text { Total: } 2\end{array}$ & $\begin{array}{l}\text { I1: ? } \\
\mathrm{C} 1: ?\end{array}$ \\
\hline $\begin{array}{l}\text { [\%] drop- } \\
\text { outs due to } \\
\text { adverse } \\
\text { events (I1/ } \\
\text { I2 / C1 / } \\
\text { total) }\end{array}$ & $\begin{array}{l}\text { I1: } 0.9 \% \\
\text { C1: } 0.0 \% \\
\text { total: } 0.4 \%\end{array}$ & $\begin{array}{l}\text { hypogly- } \\
\text { caemic } \\
\text { events } \\
\text { - NA other } \\
\text { events - } \\
\text { NA overall } \\
\text { events - I1: } \\
2.1 ; \mathrm{I} 2: 1 \text {. } \\
8 ; \mathrm{C} 1: 3.0\end{array}$ & $\begin{array}{l}\text { I1: } 2.3 \% \\
\text { C1: } 0.6 \%\end{array}$ & $\begin{array}{l}\text { I1: } 1.3 \% \\
\text { C1: } 1.7 \%\end{array}$ & $\begin{array}{l}\text { I1: } 1.7 \% / \\
\text { C1: } 2.1 \%\end{array}$ & 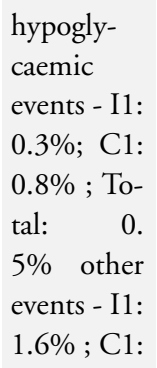 & $\begin{array}{l}\text { I1: } 3.5 \% \\
\text { C1:2.7\% } \\
\text { Total: nr }\end{array}$ & $\begin{array}{l}\text { drop-outs } \\
\text { due to seri- } \\
\text { ous adverse } \\
\text { events I1: } \\
1.6 \% \mathrm{C} 1 \text { : } \\
2.0 \%\end{array}$ & $\begin{array}{l}\text { I1:? } \\
\text { C1:? }\end{array}$ \\
\hline
\end{tabular}




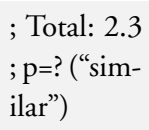

1.0 ; Total:

$1.3 \%$ over-

all events -

NA

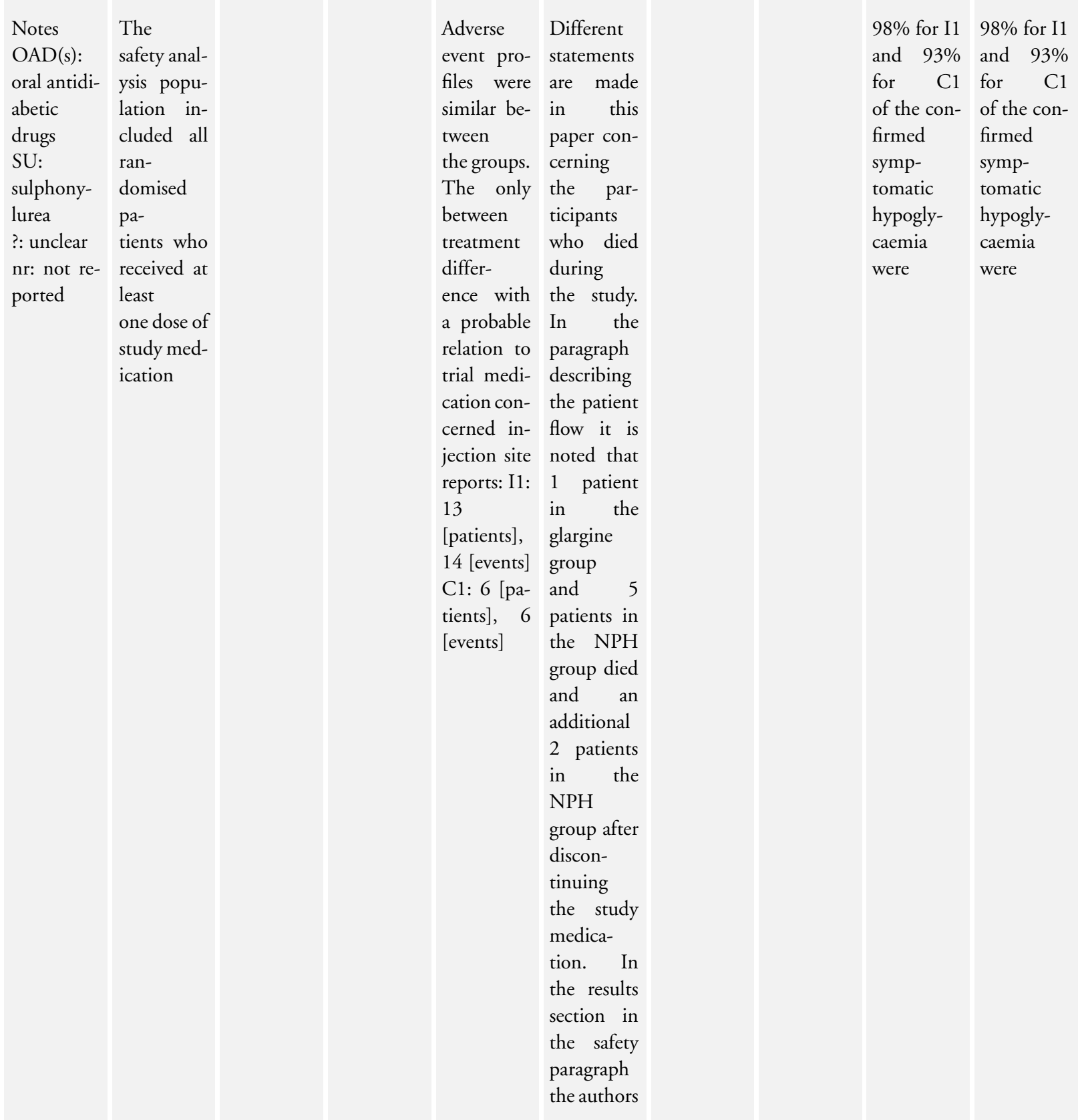


Appendix 4. Primary outcomes

\begin{tabular}{|c|c|c|c|c|c|c|c|c|c|}
\hline $\begin{array}{l}\text { Charac- } \\
\text { teristic }\end{array}$ & $\begin{array}{l}\text { Eliasche- } \\
\text { witz } \\
2006\end{array}$ & $\begin{array}{l}\text { Fritsche } \\
2003\end{array}$ & $\begin{array}{l}\text { Haak } \\
2005\end{array}$ & $\begin{array}{l}\text { Her- } \\
\text { mansen } \\
2006\end{array}$ & $\begin{array}{l}\text { Massi } \\
2003\end{array}$ & $\begin{array}{l}\text { Riddle } \\
2003\end{array}$ & $\begin{array}{l}\text { Rosen- } \\
\text { stock } \\
2001\end{array}$ & $\begin{array}{l}\text { Yki- } \\
\text { Järvinen } \\
2006\end{array}$ & $\begin{array}{l}\text { Yokoyama } \\
2006\end{array}$ \\
\hline $\begin{array}{l}\text { Inter- } \\
\text { vention } 1 \\
\text { (I1) Inter- } \\
\text { vention } 2 \\
\text { (I2) Con- } \\
\text { trol } 1 \text { (C1) }\end{array}$ & 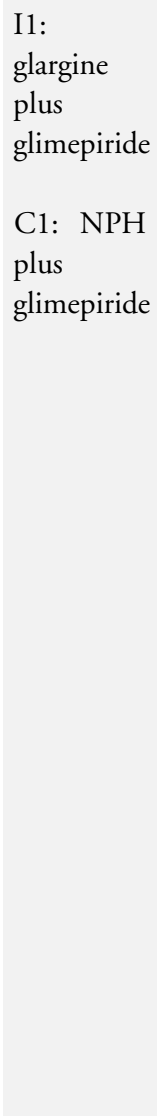 & $\begin{array}{l}\text { I1: } \\
\text { glargine } \\
\text { in the } \\
\text { morning } \\
+3 \mathrm{mg} \\
\text { glimepiride } \\
\text { I2: } \\
\text { glargine at } \\
\text { bedtime } \\
+3 \text { mg } \\
\text { glimepiride } \\
\text { C1: NPH } \\
\text { at bedtime } \\
+\quad 3 \mathrm{mg} \\
\text { glimepiride }\end{array}$ & $\begin{array}{l}\text { I1: detemir } \\
\text { once daily } \\
\text { subcuta- } \\
\text { neously } \\
\text { at bedtime } \\
\text { or detemir } \\
\text { twice daily } \\
\text { in } \\
\text { the morn- } \\
\text { ing and } \\
\text { at bedtime } \\
+ \text { mealtime } \\
\text { insulin as- } \\
\text { part } \\
\text { C1: NPH } \\
\text { once daily } \\
\text { subcuta- } \\
\text { neously at } \\
\text { bedtime or } \\
\text { NPH } \\
\text { twice daily } \\
\text { in } \\
\text { the morn- } \\
\text { ing and } \\
\text { at bedtime } \\
+ \text { mealtime } \\
\text { insulin as- } \\
\text { part }\end{array}$ & $\begin{array}{l}\text { I1: detemir } \\
\text { (twice } \\
\text { daily) } \\
\text { plus OAD } \\
\text { (met- } \\
\text { formin, } \\
\text { insulin } \\
\text { secreta- } \\
\text { gogues, } \\
\text { alpha-glu- } \\
\text { cosidase } \\
\text { inhibitors) } \\
\text { C1: NPH } \\
\text { (twice } \\
\text { daily) } \\
\text { plus OAD } \\
\text { (met- } \\
\text { formin, } \\
\text { insulin } \\
\text { secreta- } \\
\text { gogues, } \\
\text { alpha-glu- } \\
\text { cosidase } \\
\text { inhibitors) }\end{array}$ & $\begin{array}{l}\text { I1: } \\
\text { glargine } \\
\text { once daily } \\
\text { subcuta- } \\
\text { neously at } \\
\text { bedtime } \\
+\quad \text { previ- } \\
\text { ous oral } \\
\text { antihyper- } \\
\text { glycaemic } \\
\text { agents } \\
\text { continued } \\
\text { C1: NPH } \\
\text { once daily } \\
\text { subcuta- } \\
\text { neously at } \\
\text { bedtime } \\
+\quad \text { previ- } \\
\text { ous oral } \\
\text { antihyper- } \\
\text { glycaemic } \\
\text { agents } \\
\text { continued }\end{array}$ & $\begin{array}{l}\text { I1: sub- } \\
\text { cutaneous } \\
\text { glargine } \\
\text { once at } \\
\text { bedtime } \\
\text { plus oral } \\
\text { antihyper- } \\
\text { glycaemic } \\
\text { agents } \\
\text { (one or } \\
\text { two of } \\
\text { SU, met- } \\
\text { formin, } \\
\text { glitazones) } \\
\text { continued } \\
\text { at prestudy } \\
\text { dosages } \\
\text { C1: sub- } \\
\text { cutaneous } \\
\text { NPH once } \\
\text { at bedtime } \\
\text { plus oral } \\
\text { antihyper- } \\
\text { glycaemic } \\
\text { agents } \\
\text { (one or } \\
\text { two of } \\
\text { SU, met- }\end{array}$ & $\begin{array}{l}\text { I1: } \\
\text { glargine } \\
\text { once daily } \\
\text { subcuta- } \\
\text { neously at } \\
\text { bed- } \\
\text { time + pre- } \\
\text { meal regu- } \\
\text { lar insulin } \\
\text { C1: NPH } \\
\text { once at } \\
\text { bedtime or } \\
\text { twice daily } \\
\text { in } \\
\text { the morn- } \\
\text { ing and } \\
\text { at bedtime } \\
\text { subcuta- } \\
\text { neously } \\
+ \text { premeal } \\
\text { regular in- } \\
\text { sulin }\end{array}$ & $\begin{array}{l}\text { I1: } \\
\text { glargine } \\
\text { once } \\
\text { at bedtime } \\
\text { plus met- } \\
\text { formin } \mathrm{C} 1 \text { : } \\
\mathrm{NPH} \text { once } \\
\text { at bedtime } \\
\text { plus met- } \\
\text { formin }\end{array}$ & $\begin{array}{l}\text { I1: } \\
\text { glargine in } \\
\text { the morn- } \\
\text { ing plus as- } \\
\text { part } \\
\text { / lispro at } \\
\text { each } \\
\text { meal with } \\
\text { or without } \\
\text { OADs } \\
\text { C1: NPH } \\
\text { at bedtime } \\
\text { plus aspart } \\
\text { / lispro at } \\
\text { each } \\
\text { meal with } \\
\text { or without } \\
\text { OADs }\end{array}$ \\
\hline
\end{tabular}


formin,

glitazones)

continued

at prestudy

dosages

\begin{tabular}{|c|c|c|c|c|c|c|c|c|c|}
\hline $\begin{array}{l}\text { Num- } \\
\text { ber (\%) of } \\
\text { symp- } \\
\text { tomatic } \\
\text { hypogly- } \\
\text { caemia }\end{array}$ & $\begin{array}{l}\text { pa- } \\
\text { tients with } \\
\text { episodes } \\
\text { I1: } \quad 122 \\
(52.8 \%) \\
\text { C1: } \quad 157 \\
(62.8 \%) \\
\mathrm{p}=0.042 \\
\mathrm{RR}=1.27 \\
(95 \% \mathrm{CI} 1 . \\
03 \text { to } 1.57)\end{array}$ & $\begin{array}{l}\text { pa- } \\
\text { tients with } \\
\text { episodes } \\
\text { I1: } 133 \\
(56 \%) \\
\text { I2: } \quad 98 \\
(43 \%) \\
\text { C1: } 135 \\
(58 \%) \\
\text { p = } 0.001 \\
\text { (I2 vs. C1) }\end{array}$ & ? & $\begin{array}{l}\text { pa- } \\
\text { tients with } \\
\text { episodes } \\
\text { I1: } \quad 124 \\
(52 \%) \text { C1: } \\
160(67 \%) \\
\text { episodes } \\
\text { I1: } \quad 519 \\
\text { C1: } 923\end{array}$ & $\begin{array}{l}\text { pa- } \\
\text { tients with } \\
\text { episodes } \\
\text { I1: } \quad 35 \% \\
\text { C1: } 41 \% \\
P=\text { ns }\end{array}$ & $\begin{array}{l}\text { Episodes } \\
\text { per patient } \\
\text { / year I1: } \\
13.9 \\
\mathrm{C} 1: 17.7 \\
\mathrm{P}<0.02\end{array}$ & $\begin{array}{l}\text { I1: 159, } \\
61.4 \% \\
\text { [patients] } \\
\mathrm{C} 1: \quad 173, \\
66.8 \% \\
\text { [patients] }\end{array}$ & $\begin{array}{l}\text { Episodes } \\
\text { per patient } \\
\text { / year: not } \\
\text { confirmed } \\
\text { I1: } 5.4 \mathrm{C} 1 \text { : } \\
8.0 \mathrm{p}=0 . \\
12 \\
\text { confirmed } \\
\text { I1: } 5.0 \mathrm{C} 1 \text { : } \\
7.7 \\
\text { ns }\end{array}$ & $\begin{array}{l}\text { I1: ? } \\
\text { C1:? }\end{array}$ \\
\hline $\begin{array}{l}\text { Num- } \\
\text { ber (\%) of } \\
\text { overall hy- } \\
\text { pogly- } \\
\text { caemia }\end{array}$ & $\begin{array}{l}\mathrm{I} 1: \mathrm{nr} \\
\mathrm{C} 1: \mathrm{nr}\end{array}$ & $\begin{array}{l}\text { pa- } \\
\text { tients with } \\
\text { episodes } \\
\text { I1: } 175 \\
(74 \%) \\
\text { I2: } \quad 155 \\
(68 \%) \mathrm{C} 1: \\
173(75 \%)\end{array}$ & $\begin{array}{l}\text { pa- } \\
\text { tients with } \\
\text { episodes } \\
\text { I1: } \quad 171 \\
(50.1 \%) \\
\text { C1: } \quad 95 \\
(57.9 \%) \\
\text { episodes } \\
\text { I1: } \quad 1507 \\
\text { C1: } 962\end{array}$ & $\begin{array}{l}\text { pa- } \\
\text { tients with } \\
\text { episodes } \\
\text { I1: } 151 \\
(64 \%) \mathrm{C} 1 \text { : } \\
\text { 191 (80\%) } \\
\text { episodes } \\
\text { I1: } 908 \\
\text { C1: } 1688\end{array}$ & ? & ? & ? & $\begin{array}{l}\text { I1: ? } \\
\text { C1: ? }\end{array}$ & $\begin{array}{l}\text { Episodes } \\
\text { per patient } \\
\text { / month } \\
\text { I1: } \\
0.78(95 \% \\
\text { CI } 0.63 \text { to } \\
0.96) \\
\text { C1: } \\
0.79 \text { (95\% } \\
\text { CI } 0.63 \text { to } \\
0.99)\end{array}$ \\
\hline
\end{tabular}

\begin{tabular}{|c|c|c|c|c|c|c|c|c|c|}
\hline $\begin{array}{l}\text { Number } \\
\text { (\%) of se- } \\
\text { vere hypo- } \\
\text { glycaemia }\end{array}$ & $\begin{array}{l}\text { patients } \\
\text { with severe } \\
\text { symp- } \\
\text { tomatic } \\
\text { episodes } \\
\text { I1: } 6 \quad(2 . \\
6 \%) \\
\mathrm{C} 1: 11(4 . \\
4 \%) \mathrm{p}=0 . \\
303 \mathrm{RR}=1 . \\
02 \\
(95 \% \mathrm{CI} 0 . \\
99 \text { to } 1.05)\end{array}$ & $\begin{array}{l}\text { pa- } \\
\text { tients with } \\
\text { episodes } \\
\text { I1: } 5 \quad(2 . \\
1 \%) \\
\text { I2: } 4 \quad(1 . \\
8 \%) \\
\text { C1: } 6 \quad(2 . \\
6 \%)\end{array}$ & $\begin{array}{l}\text { pa- } \\
\text { tients with } \\
\text { episodes } \\
\text { I1: } 6 \quad(1 . \\
8 \%) ; \mathrm{C} 1: 3 \\
(1.8 \%) \\
\text { episodes } \\
\text { I1: 7;C1: } 8\end{array}$ & $\begin{array}{l}\text { pa- } \\
\text { tients with } \\
\text { episodes } \\
\text { I1: } \\
(<1 \%) ; \\
\text { C1: 6 (3\%) } \\
\text { episodes } \\
\text { I1: } 1 ; \text { C1: } 8\end{array}$ & $\begin{array}{l}\text { pa- } \\
\text { tients with } \\
\text { episodes } \\
\text { I1: nr (1. } \\
7 \%) \\
\text { C1: nr (1. } \\
1 \%)\end{array}$ & $\begin{array}{l}\text { I1: } 9 \text { [pa- } \\
\text { tients with } \\
\text { events]; } 14 \\
\text { [events] } \\
\text { C1: } 7 \text { [pa- } \\
\text { tients with } \\
\text { events]; } 9 \\
\text { [events] ns }\end{array}$ & $\begin{array}{l}\text { I1: } 1, \quad 0 . \\
4 \% \\
\text { C1: } 6,2 . \\
3 \% \mathrm{P}=0 . \\
0581\end{array}$ & $\begin{array}{l}\text { I1: } 0 \\
\text { C1: } 0\end{array}$ & $\begin{array}{l}\text { I1: } 0 \\
\text { C1: } 0\end{array}$ \\
\hline
\end{tabular}

\begin{tabular}{|c|c|c|c|c|c|c|c|c|c|}
\hline $\begin{array}{l}\text { Num- } \\
\text { ber (\%) of } \\
\text { noctur- }\end{array}$ & $\begin{array}{l}\text { pa- } \\
\text { tients with } \\
\text { confirmed }\end{array}$ & $\begin{array}{l}\text { pa- } \\
\text { tients with } \\
\text { episodes }\end{array}$ & $\begin{array}{l}\text { pa- } \\
\text { tients with } \\
\text { episodes }\end{array}$ & $\begin{array}{l}\text { pa- } \\
\text { tients with } \\
\text { episodes }\end{array}$ & $\begin{array}{l}\text { pa- } \\
\text { tients with } \\
\text { episodes }\end{array}$ & $\begin{array}{l}\mathrm{I} 1: \quad 4.0 \\
\text { [events/pa- } \\
\text { tient/year] }\end{array}$ & $\begin{array}{l}\text { I1: } 81,31 . \\
3 \% \quad[\mathrm{pa}- \\
\text { tients with }\end{array}$ & $\begin{array}{l}\text { I1: ? } \\
\text { C1: ? }\end{array}$ & $\begin{array}{l}\text { few } \\
\text { episodes of } \\
\text { noctur- }\end{array}$ \\
\hline $\begin{array}{l}\text { nal hypo- } \\
\text { glycaemia }\end{array}$ & $\begin{array}{l}\text { nocturnal } \\
\text { episodes }\end{array}$ & $\begin{array}{ll}\text { I1: } & 39 \\
(17 \%) & \end{array}$ & $\begin{array}{l}\text { I1: } 59(17 . \\
3 \%)\end{array}$ & $\begin{array}{ll}\text { I1: } & 71 \\
(30 \%) & \text { C1: }\end{array}$ & $\begin{array}{ll}\text { I1: } & \text { nr } \\
(12 \%) & \end{array}$ & $\begin{array}{l}\text { C1: } 6 . \\
9[\text { events/ }\end{array}$ & $\begin{array}{l}\text { episode] } \\
\text { C1: } 104,\end{array}$ & & $\begin{array}{l}\text { nal hypo- } \\
\text { glycaemia }\end{array}$ \\
\hline
\end{tabular}




\begin{tabular}{|c|c|c|c|c|c|c|c|c|c|}
\hline & $\begin{array}{l}\text { I1: } 39 \text { (16. } \\
9 \%) \\
\text { C1: } \\
(30 . \\
0 \%) \quad \mathrm{p}<0 . \\
010 \mathrm{RR}=1 \text {. } \\
19 \\
(95 \% \mathrm{CI} 1 . \\
07 \text { to } 1.31)\end{array}$ & $\begin{array}{ll}\text { I2: } & 52 \\
(23 \%) & \\
\text { C1: } & 89 \\
(38 \%) & \text { p < } \\
0.001 & \text { (I1/ } \\
\text { I2 vs. } & \text { C1) }\end{array}$ & $\begin{array}{l}; \mathrm{C} 1: 46 \\
(28.0 \%) \\
\text { episodes } \\
\text { I1: } 201 ; \\
\text { C1: } 112\end{array}$ & $\begin{array}{l}112(47 \%) \\
\text { episodes } \\
\text { I1: } \quad 160 \\
\text { C1: } 349\end{array}$ & $\begin{array}{l}\text { C1: } \quad \text { nr } \\
(24 \%) \\
P=0.0002\end{array}$ & $\begin{array}{l}\text { patient/ } \\
\text { year] } \quad \mathrm{P}<0 \text {. } \\
001\end{array}$ & $\begin{array}{l}40.2 \% \\
\text { [pa- } \\
\text { tients with } \\
\text { episode] P } \\
=0.0160\end{array}$ & & $\begin{array}{l}\text { in either } \\
\text { group }\end{array}$ \\
\hline HbA1c \% & $\begin{array}{l}\text { Change in } \\
\text { HbAlc } \\
\text { from base- } \\
\text { line to end } \\
\text { of study } \\
\text { [mean, } \\
\text { SD] PP- } \\
\text { popu- } \\
\text { lation: I1:- } \\
1.38 \text { (1.32 } \\
\text { SD) C1: - } \\
1.44 \quad(1 . \\
33 \text { SD) ad- } \\
\text { justed } \\
\text { mean dif- } \\
\text { ference: }-0 . \\
047 \text { (90\% } \\
\text { CI } 0.232 \\
\text { to } 0.138) \\
\text { full anal- } \\
\text { ysis popu- } \\
\text { lation: ad- } \\
\text { justed } \\
\text { mean dif- } \\
\text { ference: }-0 \text {. } \\
029 \text { (90\% } \\
\text { CI -0.210 } \\
\text { to } 0.153) \text {; } \\
\text { p=0.8 }\end{array}$ & 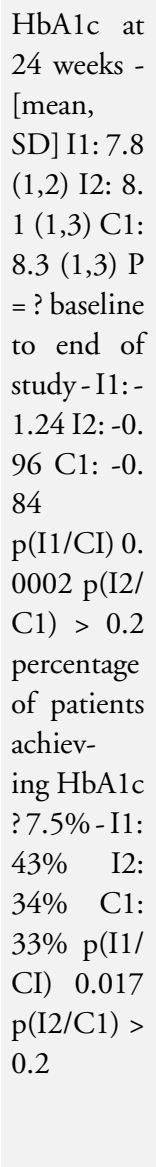 & $\begin{array}{l}\text { HbAlc at } \\
26 \text { weeks - } \\
\text { I1: } 7.6(0 . \\
1 \mathrm{SE})[\mathrm{n}= \\
315] \\
\mathrm{C} 1: 7.5(0 . \\
1 \mathrm{SE})[\mathrm{n}= \\
155] \text { ?: } 0 . \\
16 ; 95 \% \mathrm{CI} \\
(0.003-0 . \\
312) \\
? \text { baseline } \\
\text { to end of } \\
\text { study - I1: } \\
-0.2 ; \mathrm{p}=0 . \\
004 \mathrm{C} 1:- \\
0.4 ; \mathrm{p}=0 . \\
0001\end{array}$ & $\begin{array}{l}\text { A1c (base- } \\
\text { line, coun- } \\
\text { try- } \\
\text {, and OAD } \\
\text { adjusted } \\
\text { means) } \\
\text { [mean, SE? } \\
\text { ] } \\
\text { I1: } 6.58 \% \\
(0.06 \text { SE?) } \\
(\mathrm{n}=230) \\
\text { C1: } 6.46 \% \\
(0.06 \text { SE? } \\
\text { ) (n=232) } \\
\text { mean dif- } \\
\text { ference: } \\
0.13 \text { (95\% } \\
\text { CI } 0.00 \text { to } \\
0.25)\end{array}$ & $\begin{array}{l}\text { change } \\
\text { of HbAlc } \\
\text { from base- } \\
\text { line to end- } \\
\text { point } \\
\text { I1: }-0.46 \% \\
\text { C1: } \\
-0.38 \% \quad \text { P } \\
=0.415 \text { by } \\
\text { week } \\
52 \quad \text { I1: }-0 . \\
41 \% \\
\text { C1: } \\
32 \%\end{array}$ & $\begin{array}{l}\text { HbAlc at } \\
24 \text { weeks - } \\
\text { I1: } 7 . \\
0 \mathrm{C} 1: 7.0- \\
0.03 \%(-0 \text {. } \\
13 \text { to } 0.08) \\
\text { ? baseline } \\
\text { to end of } \\
\text { study - I1: } \\
-1.65 \text { C1: } \\
-1.59 \text { per- } \\
\text { centage } \\
\text { of patients } \\
\text { achiev- } \\
\text { ing HbA1c } \\
\text { ?7\% with- } \\
\text { out noc- } \\
\text { turnal hy- } \\
\text { po- } \\
\text { glycaemia- } \\
\text { I1: } 33 \% \\
\text { C1: } 27 \% \\
\text { p<0.05 }\end{array}$ & $\begin{array}{l}\text { change of } \\
\text { Hbalc } \\
\text { from base- } \\
\text { line to end } \\
\text { point } \\
\text { I1: }-0.41 \% \\
\text { C1: } \quad-0 \text {. } \\
59 \% \quad 95 \% \\
\text { CI }(0.00- \\
0.35)\end{array}$ & $\begin{array}{l}\text { HbA1c } \\
\text { at baseline } \\
\text { and end of } \\
\text { study } \\
\text { [mean, SE] } \\
\text { I1: } \\
\text { baseline - } \\
9.13 \% \text {, (0. } \\
15 \text { SE) end } \\
\text { of study - } \\
7.14 \%,(0 . \\
12 \text { SE) C1: } \\
\text { baseline - } \\
9.26 \%,(0 . \\
15 \text { SE) end } \\
\text { of study - } \\
7.16 \%,(0 . \\
14 \text { SE) }\end{array}$ & $\begin{array}{l}\text { HbA1c at } \\
6 \text { month } \\
\text { I1: } 6.6 \% \\
\mathrm{C} 1: 7.0 \% \\
\mathrm{P}=0.007 \text {, } \\
\text { adjusted } \\
\text { mean } \\
\text { change be- } \\
\text { tween- } \\
\text { treatment } \\
\text { differ- } \\
\text { ence } 0.5 \% \\
(95 \% \mathrm{CI} 0 . \\
1 \text { to } 0.8)\end{array}$ \\
\hline $\begin{array}{l}\text { Notes } \\
\text { OAD(s): } \\
\text { oral antidi- } \\
\text { abetic } \\
\text { drugs } \\
\text { SU: } \\
\text { sulphony- } \\
\text { lurea } \\
\text { ?: unclear }\end{array}$ & $\begin{array}{l}\text { Full anal- } \\
\text { ysis popu- } \\
\text { lation in- } \\
\text { cluded all } \\
\text { ran- } \\
\text { domised } \\
\text { pa- } \\
\text { tients who } \\
\text { received }\end{array}$ & & $\begin{array}{l}\text { insulin de- } \\
\text { temir was } \\
\text { consid- } \\
\text { ered non- } \\
\text { inferior be- } \\
\text { cause the } \\
\text { upper limit } \\
\text { of the } 95 \% \\
\text { CI was }<0 \text {. }\end{array}$ & & $\begin{array}{l}\text { The re- } \\
\text { ported } \\
\text { results are } \\
\text { based on } \\
\text { an ITT } \\
\text { popu- } \\
\text { lation, } \\
\text { which is } \\
\text { defined as }\end{array}$ & & & $\begin{array}{l}\text { The base- } \\
\text { line values } \\
\text { for HbAlc } \\
\text { given for } \\
\text { the ITT } \\
\text { groups } \\
\text { in Table } 1 \\
\text { (I1: } 9.5 \% \text {, }\end{array}$ & \\
\hline
\end{tabular}




$\begin{array}{ll}\text { PP: per } & \text { at least one } \\ \text { protocol } & \text { dose of the } \\ \text { ITT: in- } & \text { study med- } \\ \text { tention to } & \text { ication and } \\ \text { treat } & \begin{array}{l}\text { had at least } \\ \text { one effi- } \\ \end{array} \\ & \text { cacy value } \\ & \text { recorded } \\ & \text { during } \\ & \text { treatment } \\ & \text { phase }\end{array}$

$4 \%$ for the
dif-
ference in
HbA1c at
the end of
study; re-
sults of a
per proto-
col-
analysis are
reported in
the
FDA med-
ical report
- I1: 7.6\%
$(n=297) \quad$
$C 1: 7.4 \%$
$(n=147)$

\begin{tabular}{l|l|}
\hline $\begin{array}{l}\text { all sub- } \\
\text { jects ran- } \\
\text { domised }\end{array}$ & $\begin{array}{l}\text { C1: } 9.6 \%) \\
\text { differ from } \\
\text { the later re- }\end{array}$ \\
and treated & ported \\
and having & baseline \\
\hline both a pre- & val- \\
\hline treatment & ues (I1: 9. \\
and an on- & $13 \%, \mathrm{C} 1:$ \\
treatment & $9.26 \%)$ \\
\hline
\end{tabular}

value. The

size of the

ITT popu-

lation was

different

for each

variable.

Patients

with

missing

baseline

values or

no value

during

treatment

were

excluded

from

analyses.

Unfortu-

nately it

remains

unclear

how many

patients

were

considered

in the

analyses

of the

variables

of interest.

It remains

unclear

why there

are differ-

ent values

for change

of $\mathrm{HbAlc}$

reported 
Appendix 5. Secondary outcomes

\begin{tabular}{|c|c|c|c|c|c|c|c|c|c|}
\hline $\begin{array}{l}\text { Charac- } \\
\text { teristic }\end{array}$ & $\begin{array}{l}\text { Eliasche- } \\
\text { witz } \\
2006\end{array}$ & $\begin{array}{l}\text { Fritsche, } \\
2003\end{array}$ & $\begin{array}{l}\text { Haak, } \\
2005\end{array}$ & $\begin{array}{l}\text { Her- } \\
\text { mansen } \\
2006\end{array}$ & $\begin{array}{l}\text { Massi, } \\
2003\end{array}$ & $\begin{array}{l}\text { Riddle, } \\
2003\end{array}$ & $\begin{array}{l}\text { Rosen- } \\
\text { stock, } \\
2001\end{array}$ & $\begin{array}{l}\text { Yki- } \\
\text { Järvinen } \\
2006\end{array}$ & $\begin{array}{l}\text { Yokoyama } \\
2006\end{array}$ \\
\hline $\begin{array}{l}\text { Inter- } \\
\text { vention } 1 \\
\text { (I1) Inter- } \\
\text { vention } 2 \\
\text { (I2) Con- } \\
\text { trol } 1 \text { (C1) }\end{array}$ & $\begin{array}{l}\text { I1: } \\
\text { glargine } \\
\text { plus } \\
\text { glimepiride } \\
\text { C1: NPH } \\
\text { plus } \\
\text { glimepiride }\end{array}$ & $\begin{array}{l}\text { I1: } \\
\text { glargine } \\
\text { in the } \\
\text { morning } \\
+3 \mathrm{mg} \\
\text { glimepiride } \\
\text { I2: } \\
\text { glargine at } \\
\text { bedtime } \\
+3 \mathrm{mg} \\
\text { glimepiride } \\
\text { C1: NPH } \\
\text { at bedtime } \\
+3 \mathrm{mg} \\
\text { glimepiride }\end{array}$ & $\begin{array}{l}\text { I1: detemir } \\
\text { once daily } \\
\text { subcuta- } \\
\text { neously } \\
\text { at bedtime } \\
\text { or detemir } \\
\text { twice daily } \\
\text { in } \\
\text { the morn- } \\
\text { ing and } \\
\text { at bedtime } \\
+ \text { mealtime } \\
\text { insulin as- } \\
\text { part } \\
\text { C1: NPH } \\
\text { once daily } \\
\text { subcuta- } \\
\text { neously at } \\
\text { bedtime or } \\
\text { NPH } \\
\text { twice daily } \\
\text { in } \\
\text { the morn- } \\
\text { ing and } \\
\text { at bedtime } \\
+ \text { mealtime } \\
\text { insulin as- } \\
\text { part }\end{array}$ & $\begin{array}{l}\text { I1: detemir } \\
\text { (twice } \\
\text { daily) } \\
\text { plus OAD } \\
\text { (met- } \\
\text { formin, } \\
\text { insulin } \\
\text { secreta- } \\
\text { gogues, } \\
\text { alpha-glu- } \\
\text { cosidase } \\
\text { inhibitors) } \\
\text { C1: NPH } \\
\text { (twice } \\
\text { daily) } \\
\text { plus OAD } \\
\text { (met- } \\
\text { formin, } \\
\text { insulin } \\
\text { secreta- } \\
\text { gogues, } \\
\text { alpha-glu- } \\
\text { cosidase } \\
\text { inhibitors) }\end{array}$ & $\begin{array}{l}\text { I1: } \\
\text { glargine } \\
\text { once daily } \\
\text { subcuta- } \\
\text { neously at } \\
\text { bedtime } \\
+\quad \text { previ- } \\
\text { ous oral } \\
\text { antihyper- } \\
\text { glycaemic } \\
\text { agents } \\
\text { continued } \\
\text { C1: NPH } \\
\text { once daily } \\
\text { subcuta- } \\
\text { neously at } \\
\text { bedtime } \\
+\quad \text { previ- } \\
\text { ous oral } \\
\text { antihyper- } \\
\text { glycaemic } \\
\text { agents } \\
\text { continued }\end{array}$ & $\begin{array}{l}\text { I1: sub- } \\
\text { cutaneous } \\
\text { glargine } \\
\text { once at } \\
\text { bedtime } \\
\text { plus oral } \\
\text { antihyper- } \\
\text { glycaemic } \\
\text { agents } \\
\text { (one or } \\
\text { two of } \\
\text { SU, met- } \\
\text { formin, } \\
\text { glitazones) } \\
\text { continued } \\
\text { at prestudy } \\
\text { dosages } \\
\text { C1: sub- } \\
\text { cutaneous } \\
\text { NPH once } \\
\text { at bedtime } \\
\text { plus oral } \\
\text { antihyper- } \\
\text { glycaemic } \\
\text { agents } \\
\text { (one or } \\
\text { two of } \\
\text { SU, met- } \\
\text { formin, } \\
\text { glitazones) } \\
\text { continued } \\
\text { at prestudy } \\
\text { dosages }\end{array}$ & $\begin{array}{l}\text { I1: } \\
\text { glargine } \\
\text { once daily } \\
\text { subcuta- } \\
\text { neously at } \\
\text { bed- } \\
\text { time + pre- } \\
\text { meal regu- } \\
\text { lar insulin } \\
\text { C1: NPH } \\
\text { once at } \\
\text { bedtime or } \\
\text { twice daily } \\
\text { in } \\
\text { the morn- } \\
\text { ing and } \\
\text { at bedtime } \\
\text { subcuta- } \\
\text { neously } \\
+ \text { premeal } \\
\text { regular in- } \\
\text { sulin }\end{array}$ & $\begin{array}{l}\text { I1: } \\
\text { glargine } \\
\text { once } \\
\text { at bedtime } \\
\text { plus met- } \\
\text { formin } \mathrm{C} 1 \text { : } \\
\mathrm{NPH} \text { once } \\
\text { at bedtime } \\
\text { plus met- } \\
\text { formin }\end{array}$ & $\begin{array}{l}\text { I1: } \\
\text { glargine in } \\
\text { the morn- } \\
\text { ing plus as- } \\
\text { part } \\
\text { / lispro at } \\
\text { each } \\
\text { meal with } \\
\text { or without } \\
\text { OADs C1: } \\
\text { NPH } \\
\text { at bedtime } \\
\text { plus aspart } \\
\text { / lispro at } \\
\text { each } \\
\text { meal with } \\
\text { or without } \\
\text { OADs }\end{array}$ \\
\hline $\begin{array}{l}\text { Mortality } \\
\text { (total, dia- } \\
\text { betes spe- } \\
\text { cific and } \\
\text { cardiovas- } \\
\text { cular) }\end{array}$ & $\begin{array}{l}\text { I1: } 0 \\
\text { C1: } 0\end{array}$ & $\begin{array}{l}\mathrm{I} 1: 0 \\
\mathrm{I} 2: 2 \\
\mathrm{C} 1: 1\end{array}$ & $\begin{array}{l}\text { I1: } 1 \\
\text { C1: } 0\end{array}$ & $\begin{array}{l}\text { I1: ? } \\
\text { C1: ? }\end{array}$ & $\begin{array}{l}\text { I1: } 1 \\
\text { C1: } 5 \text { or } 6 \\
\text { or } 7 \text { Total: } \\
7 \text { or } 8\end{array}$ & $\begin{array}{l}\text { I1: ? } \\
\text { C1: ? }\end{array}$ & $\begin{array}{l}\text { I1: ? } \\
\text { C1: ? }\end{array}$ & $\begin{array}{l}\text { I1: ? } \\
\text { C1: ? }\end{array}$ & $\begin{array}{l}\text { I1: ? } \\
\text { C1: ? }\end{array}$ \\
\hline $\begin{array}{l}\text { Cardiovas- } \\
\text { cular mor- } \\
\text { bidity (e.g. }\end{array}$ & $\begin{array}{l}\text { not investi- } \\
\text { gated }\end{array}$ & $\mathrm{nr}$ & $\begin{array}{l}\text { myocardial } \\
\text { infarction } \\
\text { I1: } 0(0 \%)\end{array}$ & $\begin{array}{l}\text { not investi- } \\
\text { gated }\end{array}$ & $?$ & ?; nr & $?$ & $\begin{array}{l}\mathrm{C} 1 \text { : car- } \\
\text { diac failure } \\
\text { reported as }\end{array}$ & $\begin{array}{l}\text { not investi- } \\
\text { gated }\end{array}$ \\
\hline
\end{tabular}

Long-acting insulin analogues versus NPH insulin (human isophane insulin) for type 2 diabetes mellitus (Review) 


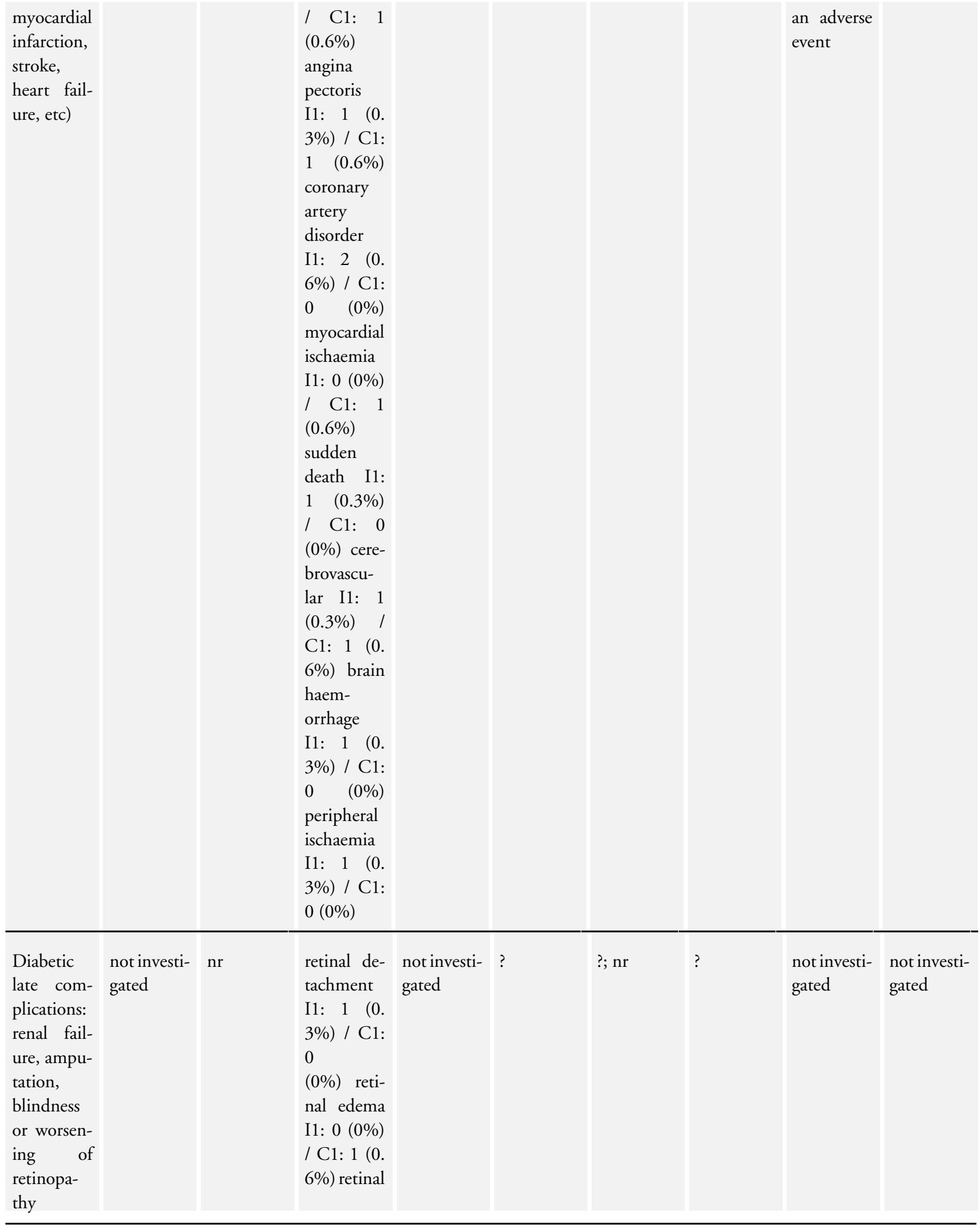

Long-acting insulin analogues versus NPH insulin (human isophane insulin) for type 2 diabetes mellitus (Review) 
disorder

I1: 20 (5.

9\%) / C1:

$10(6.1 \%)$

neuropa-

thy I1: 0

(0\%) / C1:

$1(0.6 \%)$

\begin{tabular}{|c|c|c|c|c|c|c|c|c|c|}
\hline $\begin{array}{l}\text { Quality } \\
\text { of life mea- } \\
\text { sured with } \\
\text { a validated } \\
\text { instru- } \\
\text { ment }\end{array}$ & $\begin{array}{l}\text { treat- } \\
\text { ment satis- } \\
\text { faction } \\
(\mathrm{DTSQc}) \\
: \text { I1: +4.0 } \\
\text { to } 16.6(2 \text {. } \\
6 \mathrm{SD}) \mathrm{C} 1 \text { : } \\
+3.5 \text { to } 16 \text {. } \\
0(3.3 \mathrm{SD}) \\
\mathrm{P}<0.02 \text {; } \\
\text { full analy- } \\
\text { sis popula- } \\
\text { tion }\end{array}$ & $\mathrm{nr}$ & ? & $\begin{array}{l}\text { not investi- } \\
\text { gated }\end{array}$ & ? & $\mathrm{N}$ & ? & $\begin{array}{l}\text { not investi- } \\
\text { gated }\end{array}$ & $\begin{array}{l}\text { not investi- } \\
\text { gated }\end{array}$ \\
\hline $\begin{array}{l}\text { Adverse } \\
\text { events }\end{array}$ & $\begin{array}{l}\text { see adverse } \\
\text { events }\end{array}$ & $\begin{array}{l}\text { see adverse } \\
\text { events }\end{array}$ & $\begin{array}{l}\text { see adverse } \\
\text { events }\end{array}$ & $\begin{array}{l}\text { see adverse } \\
\text { events }\end{array}$ & $\begin{array}{l}\text { see adverse } \\
\text { events }\end{array}$ & $\begin{array}{l}\text { see adverse } \\
\text { events }\end{array}$ & $\begin{array}{l}\text { see adverse } \\
\text { events }\end{array}$ & $\begin{array}{l}\text { see adverse } \\
\text { events }\end{array}$ & $\begin{array}{l}\text { see adverse } \\
\text { events }\end{array}$ \\
\hline Costs & $\begin{array}{l}\text { not } \\
\text { reported }\end{array}$ & $\mathrm{nr}$ & $?$ & $\begin{array}{l}\text { not investi- } \\
\text { gated }\end{array}$ & $?$ & $\mathrm{nr}$ & ? & $\begin{array}{l}\text { not investi- } \\
\text { gated }\end{array}$ & $\begin{array}{l}\text { not investi- } \\
\text { gated }\end{array}$ \\
\hline $\begin{array}{l}\text { Notes } \\
\text { OAD(s): } \\
\text { oral antidi- } \\
\text { abetic } \\
\text { drugs } \\
\text { SU: } \\
\text { sulphony- } \\
\text { lurea ?: un- } \\
\text { clear } \\
\text { nr: not re- } \\
\text { ported }\end{array}$ & $\begin{array}{l}\text { even } \\
\text { though in- } \\
\text { vestigated, } \\
\text { costs in re- } \\
\text { spect } \\
\text { to time lost } \\
\text { from work } \\
\text { or from } \\
\text { normal ac- } \\
\text { tivities due } \\
\text { to diabetes } \\
\text { illness were } \\
\text { not } \\
\text { reported }\end{array}$ & & & $\begin{array}{l}\text { the publi- } \\
\text { cation does } \\
\text { not clarify } \\
\text { that values } \\
\text { are means } \\
\text { and num- } \\
\text { bers fol- } \\
\text { lowing SE }\end{array}$ & & & & & \\
\hline
\end{tabular}


Appendix 6. Risk of bias

\begin{tabular}{|c|c|c|c|c|c|c|c|c|c|}
\hline $\begin{array}{l}\text { Charac- } \\
\text { teristic }\end{array}$ & $\begin{array}{l}\text { Eliasche- } \\
\text { witz } \\
2006\end{array}$ & $\begin{array}{l}\text { Fritsche } \\
2003\end{array}$ & $\begin{array}{l}\text { Haak } \\
2005\end{array}$ & $\begin{array}{l}\text { Her- } \\
\text { mansen } \\
2006\end{array}$ & $\begin{array}{l}\text { Massi } \\
2003\end{array}$ & $\begin{array}{l}\text { Riddle } \\
2003\end{array}$ & $\begin{array}{l}\text { Rosen- } \\
\text { stock } \\
2001\end{array}$ & $\begin{array}{l}\text { Yki- } \\
\text { Järvinen } \\
2006\end{array}$ & $\begin{array}{l}\text { Yokoyama } \\
2006\end{array}$ \\
\hline $\begin{array}{l}\text { Interven- } \\
\text { tion } 1 \text { (I1) } \\
\text { / interven- } \\
\text { tion } 2 \text { (I2) } \\
\text { / control } 1 \\
\text { (C1) }\end{array}$ & $\begin{array}{l}\text { I1: sub- } \\
\text { cutaneous } \\
\text { glargine } \\
\text { once at } \\
\text { bedtime } \\
\text { plus } 4 \\
\text { mg/day } \\
\text { glimepiride } \\
\text { in the } \\
\text { morning } \\
\text { C1: sub- } \\
\text { cutaneous } \\
\text { NPH once } \\
\text { at bedtime } \\
\text { plus } 4 \\
\text { mg/day } \\
\text { glimepiride } \\
\text { in the } \\
\text { morning }\end{array}$ & $\begin{array}{l}\text { I1: } \\
\text { glargine } \\
\text { in the } \\
\text { morning } \\
+3 \mathrm{mg} \\
\text { glimepiride } \\
\text { I2: } \\
\text { glargine at } \\
\text { bedtime } \\
+3 \text { mg } \\
\text { glimepiride } \\
\text { C1: NPH } \\
\text { at bedtime } \\
+3 \text { mg } \\
\text { glimepiride }\end{array}$ & $\begin{array}{l}\text { I1: detemir } \\
\text { once daily } \\
\text { subcuta- } \\
\text { neously } \\
\text { at bedtime } \\
\text { or detemir } \\
\text { twice daily } \\
\text { in } \\
\text { the morn- } \\
\text { ing and } \\
\text { at bedtime } \\
+ \text { mealtime } \\
\text { insulin as- } \\
\text { part } \\
\text { C1: NPH } \\
\text { once daily } \\
\text { subcuta- } \\
\text { neously at } \\
\text { bedtime or } \\
\text { NPH } \\
\text { twice daily } \\
\text { in } \\
\text { the morn- } \\
\text { ing and } \\
\text { at bedtime } \\
+ \text { mealtime } \\
\text { insulin as- } \\
\text { part }\end{array}$ & $\begin{array}{l}\text { I1: detemir } \\
\text { (twice } \\
\text { daily) } \\
\text { plus OAD } \\
\text { (met- } \\
\text { formin, } \\
\text { insulin } \\
\text { secreta- } \\
\text { gogues, } \\
\text { alpha-glu- } \\
\text { cosidase } \\
\text { inhibitors) } \\
\text { C1: NPH } \\
\text { (twice } \\
\text { daily) } \\
\text { plus OAD } \\
\text { (met- } \\
\text { formin, } \\
\text { insulin } \\
\text { secreta- } \\
\text { gogues, } \\
\text { alpha-glu- } \\
\text { cosidase } \\
\text { inhibitors) }\end{array}$ & $\begin{array}{l}\text { I1: } \\
\text { glargine } \\
\text { once daily } \\
\text { subcuta- } \\
\text { neously at } \\
\text { bedtime } \\
+\quad \text { previ- } \\
\text { ous oral } \\
\text { antihyper- } \\
\text { glycaemic } \\
\text { agents } \\
\text { continued } \\
\text { C1: NPH } \\
\text { once daily } \\
\text { subcuta- } \\
\text { neously at } \\
\text { bedtime } \\
+\quad \text { previ- } \\
\text { ous oral } \\
\text { antihyper- } \\
\text { glycaemic } \\
\text { agents } \\
\text { continued }\end{array}$ & $\begin{array}{l}\text { I1: sub- } \\
\text { cutaneous } \\
\text { glargine } \\
\text { once at } \\
\text { bedtime } \\
\text { plus oral } \\
\text { antihyper- } \\
\text { glycaemic } \\
\text { agents } \\
\text { (one or } \\
\text { two of } \\
\text { SU, met- } \\
\text { formin, } \\
\text { glitazones) } \\
\text { continued } \\
\text { at prestudy } \\
\text { dosages } \\
\text { C1: sub- } \\
\text { cutaneous } \\
\text { NPH once } \\
\text { at bedtime } \\
\text { plus oral } \\
\text { antihyper- } \\
\text { glycaemic } \\
\text { agents } \\
\text { (one or } \\
\text { two of } \\
\text { SU, met- } \\
\text { formin, } \\
\text { glitazones) } \\
\text { continued } \\
\text { at prestudy } \\
\text { dosages }\end{array}$ & $\begin{array}{l}\text { I1: } \\
\text { glargine } \\
\text { once daily } \\
\text { subcuta- } \\
\text { neously at } \\
\text { bed- } \\
\text { time + pre- } \\
\text { meal regu- } \\
\text { lar insulin } \\
\mathrm{C} 1 \text { : NPH } \\
\text { once at } \\
\text { bedtime or } \\
\text { twice daily } \\
\text { in } \\
\text { the morn- } \\
\text { ing and } \\
\text { at bedtime } \\
\text { subcuta- } \\
\text { neously } \\
+ \text { premeal } \\
\text { regular in- } \\
\text { sulin }\end{array}$ & $\begin{array}{l}\text { I1: } \\
\text { glargine } \\
\text { once } \\
\text { at bedtime } \\
\text { plus met- } \\
\text { formin } \mathrm{C} 1 \text { : } \\
\mathrm{NPH} \text { once } \\
\text { at bedtime } \\
\text { plus met- } \\
\text { formin }\end{array}$ & $\begin{array}{l}\text { I1: } \\
\text { glargine in } \\
\text { the morn- } \\
\text { ing plus as- } \\
\text { part } \\
\text { / lispro at } \\
\text { each } \\
\text { meal with } \\
\text { or without } \\
\text { OADs C1: } \\
\text { NPH } \\
\text { at bedtime } \\
\text { plus aspart } \\
\text { / lispro at } \\
\text { each } \\
\text { meal with } \\
\text { or without } \\
\text { OADs }\end{array}$ \\
\hline $\begin{array}{l}\text { Ran- } \\
\text { domised } \\
\text { controlled } \\
\text { clinical } \\
\text { trial } \\
\text { (RCT) }\end{array}$ & $\mathrm{Y}$ & $Y$ & $Y$ & $\mathrm{Y}$ & $Y$ & $Y$ & $Y$ & Y & $Y$ \\
\hline $\begin{array}{l}\text { Non- } \\
\text { inferior- } \\
\text { ity / equiv- }\end{array}$ & $\begin{array}{l}\text { equiva- } \\
\text { lence trial }\end{array}$ & ? & $\begin{array}{l}\text { non-inferi- } \\
\text { ority trial }\end{array}$ & $\begin{array}{l}\text { non-inferi- } \\
\text { ority trial }\end{array}$ & ? & $\mathrm{N}$ & ? & $\begin{array}{l}\text { superiority } \\
\text { trial }\end{array}$ & $\begin{array}{l}\text { superiority } \\
\text { trial }\end{array}$ \\
\hline
\end{tabular}

Long-acting insulin analogues versus NPH insulin (human isophane insulin) for type 2 diabetes mellitus (Review) 
alence trial

\begin{tabular}{|c|c|c|c|c|c|c|c|c|c|}
\hline $\begin{array}{l}\text { Controlled } \\
\text { clinical } \\
\text { trial }\end{array}$ & $\mathrm{Y}$ & Y & Y & Y & Y & $\mathrm{Y}$ & Y & Y & Y \\
\hline $\begin{array}{l}\text { De- } \\
\text { sign: par- } \\
\text { allel study, } \\
\text { crossover, } \\
\text { factorial } \\
\text { RCT }\end{array}$ & $\begin{array}{l}\text { parallel } \\
\text { study }\end{array}$ & $\begin{array}{l}\text { parallel } \\
\text { study }\end{array}$ & $\begin{array}{l}\text { parallel } \\
\text { study }\end{array}$ & $\begin{array}{l}\text { parallel } \\
\text { study }\end{array}$ & $\begin{array}{l}\text { parallel } \\
\text { study }\end{array}$ & $\begin{array}{l}\text { parallel } \\
\text { study }\end{array}$ & $\begin{array}{l}\text { parallel } \\
\text { study }\end{array}$ & $\begin{array}{l}\text { parallel } \\
\text { study }\end{array}$ & parallel \\
\hline $\begin{array}{l}\text { Crossover } \\
\text { study: } \\
\text { wash-out } \\
\text { phase }\end{array}$ & NA & NA & NA & NA & NA & NA & NA & NA & NA \\
\hline $\begin{array}{l}\text { Crossover } \\
\text { study: car- } \\
\text { ryover ef- } \\
\text { fect tested }\end{array}$ & NA & NA & NA & NA & NA & NA & NA & NA & NA \\
\hline $\begin{array}{l}\text { Crossover } \\
\text { study: pe- } \\
\text { riod effect } \\
\text { tested }\end{array}$ & NA & NA & NA & NA & NA & NA & NA & NA & NA \\
\hline $\begin{array}{l}\text { Method of } \\
\text { randomi- } \\
\text { sation }\end{array}$ & ? & ? & $\begin{array}{l}\text { Com- } \\
\text { puter gen- } \\
\text { erated ran- } \\
\text { domi- } \\
\text { sation list. } \\
\text { Block ran- } \\
\text { domisa- } \\
\text { tion within } \\
\text { individual } \\
\text { trial sites }\end{array}$ & ? & $\begin{array}{l}\text { sequen- } \\
\text { tial subject } \\
\text { numbers } \\
\text { were } \\
\text { paired } \\
\text { with treat- } \\
\text { ment } \\
\text { codes, allo- } \\
\text { cated } \\
\text { at random. } \\
\text { The sched- } \\
\text { ule was } \\
\text { prepared } \\
\text { by centre } \\
\text { and by pre- } \\
\text { treatment }\end{array}$ & $\begin{array}{l}\text { randomi- } \\
\text { sation } \\
\text { schedule } \\
\text { was gener- } \\
\text { ated by } \\
\text { Quintiles; } \\
\text { approx. 1: } \\
1 \text { ratio at } \\
\text { each site }\end{array}$ & ? & $\begin{array}{l}\text { minimi- } \\
\text { sation of } \\
\text { differences } \\
\text { between } \\
\text { the study } \\
\text { groups } \\
\text { calculated } \\
\text { for the } \\
\text { following } \\
\text { variables } \\
\text { (relative } \\
\text { weight } \\
\text { of each } \\
\text { variable } \\
\text { in paren- } \\
\text { theses): } \\
\text { age (1x) } \\
\text {; sex (0. } \\
5 x) \text { BMI }\end{array}$ & ? \\
\hline
\end{tabular}


(1.5x);

HbA1c

(1.5x);

duration

of diabetes

(0.5x);

fasting C-

peptide (1.

$0 \mathrm{x}$ ); use of

diuretics

or beta-

blocking

agents

$(0.25 \mathrm{x})$;

angioten-

sion-

converting

enzyme

inhibitors

(0.25x);

previous

use of a

sulfony-

lurea $(2 \mathrm{x})$

\begin{tabular}{|c|c|c|c|c|c|c|c|c|c|}
\hline $\begin{array}{l}\text { Unit of } \\
\text { randomi- } \\
\text { sation (in- } \\
\text { dividu- } \\
\text { als, cluster } \\
\text { - specify) }\end{array}$ & ? & individuals & individuals & ? & individuals & individuals & individuals & individuals & ? \\
\hline $\begin{array}{l}\text { Randomi- } \\
\text { sation } \\
\text { stratified } \\
\text { for centres }\end{array}$ & ? & $\mathrm{Y}$ & ? & ? & Y & $\mathrm{Y}$ & ? & $\mathrm{N}$ & $\mathrm{N}$ \\
\hline $\begin{array}{l}\text { Randomi- } \\
\text { sation ratio }\end{array}$ & $1: 1$ & $1: 1: 1$ & $2: 1$ & $1: 1$ & $1: 1$ & $1: 1$ & $1: 1$ & NA & $1: 1$ \\
\hline $\begin{array}{l}\text { Conceal- } \\
\text { ment of al- } \\
\text { location }\end{array}$ & ? & ? & $\mathrm{Y}$ & $\mathrm{Y}$ & $\mathrm{Y}$ & $\begin{array}{l}\text { Y; central- } \\
\text { ized tele- } \\
\text { phone sys- } \\
\text { tem }\end{array}$ & Y & ? & ? \\
\hline $\begin{array}{l}\text { Stated } \\
\text { blinding } \\
\text { (open; sin- } \\
\text { gle, dou- } \\
\text { ble, triple }\end{array}$ & open & open & open & open & open & open & open & open & open \\
\hline
\end{tabular}

Long-acting insulin analogues versus NPH insulin (human isophane insulin) for type 2 diabetes mellitus (Review)

Copyright $\odot 2009$ The Cochrane Collaboration. Published by John Wiley \& Sons, Ltd. 
blind)

\begin{tabular}{|c|c|c|c|c|c|c|c|c|c|}
\hline $\begin{array}{l}\text { Ac- } \\
\text { tual blind- } \\
\text { ing: partic- } \\
\text { ipant }\end{array}$ & NA & $\mathrm{N}$ & $\mathrm{N}$ & NA & $\mathrm{N}$ & $\mathrm{N}$ & $\mathrm{N}$ & NA & NA \\
\hline $\begin{array}{l}\text { Actual } \\
\text { blinding: } \\
\text { caregiver } \\
\text { / treatment } \\
\text { adminis- } \\
\text { trator }\end{array}$ & NA & $\mathrm{N}$ & $\mathrm{N}$ & NA & $\mathrm{N}$ & $\mathrm{N}$ & $\mathrm{N}$ & NA & NA \\
\hline $\begin{array}{l}\text { Actual } \\
\text { blinding: } \\
\text { outcome } \\
\text { assessor }\end{array}$ & $?$ & $?$ & $?$ & $?$ & $?$ & $?$ & $?$ & ? & $?$ \\
\hline $\begin{array}{l}\text { Ac- } \\
\text { tual blind- } \\
\text { ing: others }\end{array}$ & NA & $?$ & $?$ & NA & $?$ & $?$ & $?$ & NA & NA \\
\hline $\begin{array}{l}\text { Blinding } \\
\text { checked: } \\
\text { participant }\end{array}$ & NA & NA & NA & NA & NA & NA & NA & NA & NA \\
\hline $\begin{array}{l}\text { Blinding } \\
\text { checked: } \\
\text { caregiver } \\
\text { / treatment } \\
\text { adminis- } \\
\text { trator }\end{array}$ & NA & NA & NA & NA & NA & NA & NA & NA & NA \\
\hline $\begin{array}{l}\text { Primary } \\
\text { endpoint } \\
\text { defined } \\
\text { (power cal- } \\
\text { culation) }\end{array}$ & $\begin{array}{l}\text { change in } \\
\text { HbAlc }\end{array}$ & $\begin{array}{l}\text { change of } \\
\text { Hbalc } \\
\text { from base- } \\
\text { line to end } \\
\text { point; fre- } \\
\text { quency } \\
\text { of patients } \\
\text { with hypo- } \\
\text { glycaemic } \\
\text { episodes }\end{array}$ & $\begin{array}{l}\text { HbAlc af- } \\
\text { ter } 26 \\
\text { weeks of } \\
\text { treatment }\end{array}$ & Alc & $\begin{array}{l}\text { change } \\
\text { of HbA1c } \\
\text { from base- } \\
\text { line to end } \\
\text { point }\end{array}$ & $\begin{array}{l}\text { percentage } \\
\text { of subjects } \\
\text { achiev- } \\
\text { ing HbA1c } \\
=<7 \text {. } \\
0 \% \text { with- } \\
\text { out symp- } \\
\text { tomatic } \\
\text { confirmed } \\
\text { noctur- } \\
\text { nal hypo- } \\
\text { glycaemia }\end{array}$ & $\begin{array}{l}\text { change } \\
\text { of HbA1c } \\
\text { from base- } \\
\text { line to end } \\
\text { point }\end{array}$ & $\begin{array}{l}\text { change in } \\
\text { HbAlc }\end{array}$ & $?$ \\
\hline $\begin{array}{l}{[\mathrm{n}] \text { of pri- }} \\
\text { mary end- }\end{array}$ & 1 & 2 & 1 & 1 & 1 & 1 & 1 & 1 & ? (1) \\
\hline
\end{tabular}




\begin{tabular}{|c|c|c|c|c|c|c|c|c|c|}
\hline $\begin{array}{l}{[\mathrm{n}] \text { of sec- }} \\
\text { ondary } \\
\text { endpoints }\end{array}$ & 4 & 4 & ? & 6 & 4 & 7 & 11 & 7 & 5 \\
\hline $\begin{array}{l}\text { Total [n] of } \\
\text { endpoints }\end{array}$ & 5 & 6 & $?$ & 7 & 5 & 8 & 12 & 8 & 6 \\
\hline $\begin{array}{l}\text { Prior pub- } \\
\text { lication of } \\
\text { study } \\
\text { design }\end{array}$ & $\mathrm{N}$ & $\mathrm{N}$ & $\mathrm{N}$ & $\mathrm{N}$ & $\mathrm{N}$ & $\mathrm{N}$ & $\mathrm{N}$ & $\mathrm{N}$ & $\mathrm{N}$ \\
\hline $\begin{array}{l}\text { Outcomes } \\
\text { of prior/ } \\
\text { cur- } \\
\text { rent publi- } \\
\text { cation } \\
\text { identical }\end{array}$ & $\mathrm{Y}$ & NA & NA & $\mathrm{Y}$ & NA & NA & NA & $\mathrm{Y}$ & NA \\
\hline $\begin{array}{l}\text { Power cal- } \\
\text { culation }\end{array}$ & $\mathrm{Y}$ & $\mathrm{Y}$ & $\mathrm{Y}$ & $\mathrm{Y}$ & $\mathrm{Y}$ & $\mathrm{Y}$ & $\mathrm{Y}$ & $\mathrm{Y}$ & $\mathrm{N}$ \\
\hline $\begin{array}{l}\text { [n] partic- } \\
\text { ipants per } \\
\text { group cal- } \\
\text { culated }\end{array}$ & $\begin{array}{l}199 \\
(240 \text { with a } \\
20 \% \text { drop- } \\
\text { out rate) }\end{array}$ & $\begin{array}{l}199 \\
(240 \text { with a } \\
20 \% \text { drop- } \\
\text { out rate) }\end{array}$ & $\begin{array}{l}\text { I1: } 267 \quad / \\
\text { C1: } 133\end{array}$ & 198 & 192 & 375 & ? & $\begin{array}{l}50 \\
(55 \text { with a } \\
10 \% \text { drop- } \\
\text { out rate) }\end{array}$ & NA \\
\hline $\begin{array}{l}\text { Non- } \\
\text { inferiority } \\
\text { trial: inter- } \\
\text { val } \\
\text { for equiva- } \\
\text { lence spec- } \\
\text { ified }\end{array}$ & $\mathrm{Y}$ & $\mathrm{N}$ & $\mathrm{Y}$ & $\mathrm{Y}$ & ? & NA & $?$ & NA & NA \\
\hline $\begin{array}{l}\text { Intention- } \\
\text { to- } \\
\text { treat analy- } \\
\text { sis (ITT) }\end{array}$ & $\mathrm{Y}$ & $\mathrm{Y}$ & $\mathrm{Y}$ & $\mathrm{Y}$ & $\mathrm{Y}$ & $\mathrm{Y}$ & $\mathrm{Y}$ & $\mathrm{Y}$ & ? \\
\hline $\begin{array}{l}\text { Per- } \\
\text { protocol- } \\
\text { analysis }\end{array}$ & $\mathrm{Y}$ & $\mathrm{N}$ & $\mathrm{N}$ & $\mathrm{Y}$ & $\mathrm{N}$ & $\mathrm{N}$ & $\mathrm{N}$ & $\mathrm{N}$ & ? \\
\hline $\begin{array}{l}\text { ITT } \\
\text { defined }\end{array}$ & $\mathrm{Y}$ & $\mathrm{Y}$ & $\mathrm{Y}$ & $\mathrm{Y}$ & $\mathrm{Y}$ & $\mathrm{Y}$ & $\mathrm{Y}$ & $\mathrm{Y}$ & $\mathrm{N}$ \\
\hline
\end{tabular}


(Continued)

\begin{tabular}{|c|c|c|c|c|c|c|c|c|c|}
\hline $\begin{array}{l}\text { Analysis } \\
\text { stratified } \\
\text { for centres }\end{array}$ & $\mathrm{N}$ & $?$ & $?$ & $\mathrm{~N}$ & $?$ & Y & $?$ & $\mathrm{Y}$ & NA \\
\hline $\begin{array}{l}\text { Missing } \\
\text { data: } \\
\text { last obser- } \\
\text { vation } \\
\text { carried for- } \\
\text { ward } \\
\text { (LOCF) }\end{array}$ & $\mathrm{Y}$ & $?$ & $?$ & $\mathrm{Y}$ & $?$ & Y & $\mathrm{Y}$ & $\mathrm{N}$ & $?$ \\
\hline $\begin{array}{l}\text { Missing } \\
\text { data: } \\
\text { Other } \\
\text { methods }\end{array}$ & $\mathrm{N}$ & $?$ & $?$ & $\mathrm{~N}$ & $?$ & $\mathrm{~N}$ & $\mathrm{~N}$ & $\mathrm{~N}$ & $\mathrm{~N}$ \\
\hline $\begin{array}{l}\text { LOCF de- } \\
\text { fined }\end{array}$ & $\mathrm{Y}$ & NA & NA & $\mathrm{Y}$ & $\mathrm{N}$ & Y & $\mathrm{Y}$ & NA & NA \\
\hline $\begin{array}{l}{[\mathrm{n}]} \\
\text { of screened } \\
\text { partic- } \\
\text { ipants (I1/ } \\
\text { I2 / C1 / } \\
\text { total) }\end{array}$ & 918 & 938 & $\begin{array}{l}\text { Total: } \\
\text { ? (FDA sta- } \\
\text { tistical re- } \\
\text { port: } 545 \text { ) }\end{array}$ & 735 & Total: 687 & $\begin{array}{l}\text { I1: ? } \\
\text { C1: ? } \\
\text { Total: } \\
1381\end{array}$ & $\begin{array}{l}? \\
\text { (EMEA re- } \\
\text { port: } 846 \text { ) }\end{array}$ & 157 & $?$ \\
\hline $\begin{array}{l}{[\mathrm{n}] \text { of eligi- }} \\
\text { ble partic- } \\
\text { ipants (I1/ } \\
\text { I2 / C1 / } \\
\text { total) }\end{array}$ & $?$ & 752 & Total: ? & 476 & Total:? & $\begin{array}{l}\text { I1: ? } \\
\text { C1: ? } \\
\text { Total: ? }\end{array}$ & $?$ & 110 & $?$ \\
\hline $\begin{array}{l}{[\mathrm{n}] \text { of ran- }} \\
\text { domised } \\
\text { partic- } \\
\text { ipants (I1/ } \\
\mathrm{I} 2 \text { / C1 / } \\
\text { total) - pri- } \\
\text { mary end- } \\
\text { point }\end{array}$ & total: 528 & $\begin{array}{l}\text { I1: } 237 \\
\text { I2: } 229 \\
\text { C1: } 234 \\
\text { Total: } 700\end{array}$ & $\begin{array}{l}\text { I1: } 341 \\
\text { C1: } 164 \\
\text { total: } 505 \\
\text { (according } \\
\text { to the FDA } \\
\text { statistical } \\
\text { review } 506 \\
\text { subjects } \\
\text { were ran- } \\
\text { domised } \\
\text { and } 505 \\
\text { ran- } \\
\text { domised } \\
\text { and } \\
\text { treated) }\end{array}$ & $\begin{array}{l}\text { I1: } 237 \\
\text { C1: } 239\end{array}$ & $\begin{array}{l}\text { I1: } 293 \\
\text { C1: } 285 \\
\text { Total: } 578\end{array}$ & $\begin{array}{l}\text { I1: } 372 \\
\text { C1: } 392 \\
\text { Total: } 764\end{array}$ & $\begin{array}{l}\text { I1: } 259 \\
\text { C1: } 259 \\
\text { Total: } 518\end{array}$ & $\begin{array}{l}\text { I1: } 61 \\
\text { C1: } 49\end{array}$ & $\begin{array}{l}\text { I1: } 31 \\
\text { C1: } 31\end{array}$ \\
\hline
\end{tabular}




\begin{tabular}{|c|c|c|c|c|c|c|c|c|c|}
\hline $\begin{array}{l}\text { [n] of par- } \\
\text { tic- } \\
\text { ipants fin- } \\
\text { ishing the } \\
\text { study (I1/ } \\
\text { I2 / C1 / } \\
\text { total) }\end{array}$ & $\begin{array}{ll}\text { I1: } & 218 \\
\mathrm{C} 1: & 244 \\
\text { total: } & 462\end{array}$ & $\begin{array}{l}\text { I1: ? } \\
\text { I2: ? } \\
\text { C1: ? To- } \\
\text { tal: ? }\end{array}$ & $\begin{array}{l}\text { I1: } 315 \\
\text { C1: } 156 \\
\text { Total: } 471\end{array}$ & $\begin{array}{l}\text { I1: } 227 \\
\text { C1: } 225\end{array}$ & $\begin{array}{l}\text { I1: } 272 \\
\text { C1: } 252 \\
\text { Total: } 524\end{array}$ & $\begin{array}{l}\text { I1: ? } \\
\text { C1: ? } \\
\text { Total: ? }\end{array}$ & $\begin{array}{l}\mathrm{I1}: ? \\
\mathrm{C} 1: \text { ? } \\
\text { Total: ? }\end{array}$ & $\begin{array}{l}\text { I1: } 60 \\
\text { C1: } 48\end{array}$ & $\begin{array}{l}\text { I1:? } \\
\mathrm{C} 1: ?\end{array}$ \\
\hline $\begin{array}{l}{[\mathrm{n}] \text { of par- }} \\
\text { tici- } \\
\text { pants anal- } \\
\text { ysed (I1/ I2 } \\
\text { / C1 / to- } \\
\text { tal) }\end{array}$ & $\begin{array}{l}\text { I1: nr C1: } \\
\text { nr }\end{array}$ & $\begin{array}{l}\text { I1: } 236 \\
\text { I2: } 227 \\
\text { C1: } 232 \\
\text { Total: } 695\end{array}$ & $\begin{array}{l}\text { HbA1c } \\
\text { - I1: } 315 \text { / } \\
\text { C1: } \\
\text { 155 hypo- } \\
\text { glycaemia - } \\
\text { I1: } 341 \text { / } \\
\text { C1: } 164\end{array}$ & $\begin{array}{l}\text { I1: } 237 \\
\text { C1: } 238\end{array}$ & $\begin{array}{l}\text { I1: ? } \\
\text { C1: ? } \\
\text { Total: ? }\end{array}$ & $\begin{array}{l}\text { I1:367 } \\
\text { C1:389 } \\
\text { Total: } 756\end{array}$ & $\begin{array}{l}\text { I1: ? } \\
\text { C1: ? } \\
\text { Total: ? }\end{array}$ & $\begin{array}{l}\text { I1: } 60 \\
\text { C1: } 48\end{array}$ & $\begin{array}{l}\text { I1:? } \\
\mathrm{C} 1: ?\end{array}$ \\
\hline $\begin{array}{l}\text { Descrip- } \\
\text { tion of dis- } \\
\text { continu- } \\
\text { ing partici- } \\
\text { pants }\end{array}$ & $\mathrm{N}$ & $\mathrm{N}$ & $?$ & $\mathrm{~N}$ & $\mathrm{~N}$ & Y & $\mathrm{N}$ & Y & $\mathrm{N}$ \\
\hline $\begin{array}{l}\text { Drop-outs } \\
\text { (reasons } \\
\text { explained) }\end{array}$ & $\begin{array}{l}\text { protocol } \\
\text { violations - } \\
\text { I1: } 4 \text { / C1: } \\
3 \text { patient } \\
\text { wishes - I1: } \\
4 \text { / C1: } 1 \\
\text { poor com- } \\
\text { pliance - } \\
\text { I1: } 1 \text { / C1: } \\
1 \text { lack of ef- } \\
\text { ficacy - I1: } \\
1 / \mathrm{C} 1: 0\end{array}$ & $\begin{array}{l}\text { I1: ? } \\
\text { I2: ? } \\
\text { C1: ? } \\
\text { Total: ? }\end{array}$ & $\begin{array}{l}\mathrm{I} 1: ? \\
\mathrm{C} 1: ? \\
\text { Total:? }\end{array}$ & $\mathrm{nr}$ & $\begin{array}{l}\text { adverse } \\
\text { events - I1: } \\
1.7 \% \\
\text { / C1: } 2.1 \% \\
\text { wish to dis- } \\
\text { continue - } \\
\text { I1: } 1.7 \% \text { / } \\
\mathrm{C} 1: \text { ? poor } \\
\text { compli- } \\
\text { ance - I1: } \\
0.3 \% \text { / C1: } \\
2.1 \%\end{array}$ & $\begin{array}{l}\text { I1: ? } \\
\text { C1: ? } \\
\text { Total: ? }\end{array}$ & $\begin{array}{l}\text { I1: ? } \\
\text { C1: ? } \\
\text { Total: ? }\end{array}$ & $\mathrm{nr}$ & $\mathrm{nr}$ \\
\hline $\begin{array}{l}\text { With- } \\
\text { drawals } \\
\text { (reasons } \\
\text { explained) }\end{array}$ & $\begin{array}{l}\text { I1: } 2 \mathrm{C} 1: \\
0 \text { no reason } \\
\text { stated }\end{array}$ & $\begin{array}{l}\text { due to ad- } \\
\text { verse } \\
\text { events - I1: } \\
5 \text { / I2: } 4 \text { / } \\
\mathrm{C} 1: 7 / \text { to- } \\
\text { tal: } \quad 16 \\
\text { other - I1:? } \\
\text { / I2: ? / C1: } \\
\text { ? / total: ? }\end{array}$ & $\begin{array}{l}\text { adverse } \\
\text { events - I1: } \\
8(2.3 \%) \text { / } \\
\mathrm{C} 1: 2 \text { (1. } \\
2 \%) \text { inef- } \\
\text { fective } \\
\text { ther- } \\
\text { apy - I1: } \\
8(2.3 \%) / \\
\mathrm{C} 1: 2 \text { (1. } \\
2 \%) \text { non- } \\
\text { compli- } \\
\text { ance with }\end{array}$ & $\begin{array}{l}\text { adverse } \\
\text { events - I1: } \\
3 \text { / C1: } 4 \\
\text { ineffective } \\
\text { ther- } \\
\text { apy - I1: } 0 \text { / } \\
\text { C1: 1 non- } \\
\text { compli- } \\
\text { ance - I1: } \\
1 \text { / C1: } 3 \\
\text { other rea- } \\
\text { sons - I1: } 6 \\
\text { / C1: } 5\end{array}$ & $?$ & $\begin{array}{l}\text { withdrew } \\
\text { before re- } \\
\text { ceiving an } \\
\text { insulin in- } \\
\text { jection } \\
\text { - I1: } 5 \text { / } \\
\text { C1: } 3 \text { sub- } \\
\text { ject prefer- } \\
\text { ence - I1: } \\
15 \text { / C1: } 3 \\
\text { investiga- } \\
\text { tors discre- } \\
\text { tion, poor }\end{array}$ & $\begin{array}{l}\text { subject's } \\
\text { wish or loss } \\
\text { to follow- } \\
\text { up - I1: } 13 \\
\text { / C1: } 9 \text { ad- } \\
\text { verse event } \\
\text { - I1: } 9 / \mathrm{C} 1 \text { : } \\
7 \text { no reason } \\
\text { reported - } \\
\text { I1: } 6 \text { / C1: } \\
5\end{array}$ & $\begin{array}{l}\text { adverse } \\
\text { events - I1: } \\
1 \text { / C1: } 1\end{array}$ & $\mathrm{nr}$ \\
\hline
\end{tabular}




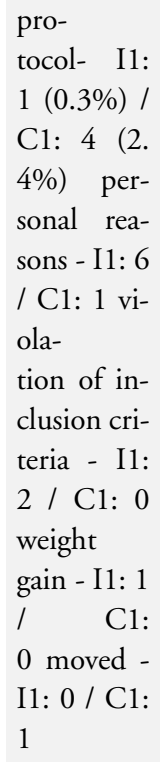

ad-

herence or lack of efficacy - I1: 3 / C1: 14 hypoglycaemia I1: 1 / C1: 3 adverse events other than hypoglycaemiaI1: 6 / C1: 4 protocol vio-

lation, loss to followup and other reasons - I1: 6 / C1: 6 no reason reported-I1: 2/ C1: 2

\begin{tabular}{|c|c|c|c|c|c|c|c|c|c|}
\hline $\begin{array}{l}\text { Losses-to- } \\
\text { follow- } \\
\text { up (reasons } \\
\text { explained) }\end{array}$ & $\begin{array}{l}\text { I1: } 1 \\
\text { C1: } 1\end{array}$ & $\begin{array}{l}\text { I1: } 1 \\
\text { I2: } 1 \\
\text { C1: } 0 \\
\text { Total: } 2\end{array}$ & $\begin{array}{l}\text { I1: ? } \\
\text { C1: ? } \\
\text { Total: ? }\end{array}$ & $\mathrm{nr}$ & $?$ & $\begin{array}{l}\text { I1: ? } \\
\text { C1: ? } \\
\text { Total: ? }\end{array}$ & $\begin{array}{l}\text { I1: ? } \\
\text { C1: ? } \\
\text { Total: ? }\end{array}$ & $\mathrm{nr}$ & $\mathrm{nr}$ \\
\hline $\begin{array}{l}\text { [n] of par- } \\
\text { tic- } \\
\text { ipants who } \\
\text { discontin- } \\
\text { ued (I1/ I2 } \\
\text { / C1 / to- } \\
\text { tal) }\end{array}$ & $\begin{array}{l}\text { I1: } 13 \\
\text { C1: } 6\end{array}$ & $\begin{array}{l}\text { I1: } 11 \\
\text { I2: } 17 \\
\text { C1: } 27 \\
\text { Total: } 55\end{array}$ & $\begin{array}{l}\text { I1: } 26 \\
\text { C1: } 9 \\
\text { Total: } 35\end{array}$ & $\begin{array}{l}\text { I1: } 10 \\
\text { C1: } 14\end{array}$ & $\begin{array}{l}\text { I1: ? } \\
\text { C1: ? } \\
\text { Total: ? }\end{array}$ & $\begin{array}{l}\text { from all } \\
\text { ran- } \\
\text { domised } \\
(764) \text { pa- } \\
\text { tients } \\
\text { I1: } 38 / 372 \\
\text { C1: } \\
35 / 392 \text { to- } \\
\text { tal: } 73\end{array}$ & $\begin{array}{l}\text { I1: ? } \\
\text { C1: ? } \\
\text { Total: ? }\end{array}$ & $\begin{array}{l}\text { I1: } 1 \\
\text { C1: } 1\end{array}$ & $\begin{array}{l}\text { I1: ? } \\
\text { C1: ? }\end{array}$ \\
\hline $\begin{array}{l}{[\%]} \\
\text { discontin- } \\
\text { uation rate } \\
\text { (I1/ I2 / C1 } \\
\text { / total) }\end{array}$ & $\begin{array}{l}\text { I1: } \quad 5.6 \% \\
\text { C1: } 2.4 \%\end{array}$ & $\begin{array}{l}\text { I1: } 4.6 \% \\
\text { I2: } 7.4 \% \\
\text { C1: } 11.5 \% \\
\text { total: } 7.9 \%\end{array}$ & $\begin{array}{l}\text { I1: } 7.6 \% \\
\text { C1: } 5 . \\
5 \% \text { Total: } \\
6.9 \%\end{array}$ & $\begin{array}{l}\text { I1: } 4.2 \% \\
\text { C1: } 5.9 \%\end{array}$ & $\begin{array}{l}\text { I1: ? } \\
\text { C1: ? } \\
\text { Total: ? }\end{array}$ & $\begin{array}{l}\text { from all } \\
\text { ran- } \\
\text { domised } \\
(764) \\
\text { patients I1: } \\
10.2 \mathrm{C} 1: 8 . \\
9 \text { total: } 9.6\end{array}$ & $\begin{array}{l}\text { I1: ? } \\
\text { C1: ? } \\
\text { Total: ? }\end{array}$ & $\begin{array}{l}\text { I1: } 1.6 \% \\
\text { C1: } 2.0 \%\end{array}$ & $\begin{array}{l}\text { I1: ? } \\
\text { C1: ? }\end{array}$ \\
\hline
\end{tabular}




\begin{tabular}{|c|c|c|c|c|c|c|c|c|c|}
\hline $\begin{array}{l}\text { Discontin- } \\
\text { uation rate } \\
\text { similar be- } \\
\text { tween } \\
\text { groups }\end{array}$ & $\mathrm{N}$ & $\mathrm{N}$ & Y & Y & ? & $\mathrm{Y}$ & ? & Y & NA \\
\hline $\begin{array}{l}{[\%]} \\
\text { crossover } \\
\text { between } \\
\text { groups }\end{array}$ & NA & ? & $?$ & NA & ? & ? & ? & NA & NA \\
\hline $\begin{array}{l}\text { Differ- } \\
\text { ences [n] } \\
\text { calculated } \\
\text { to analysed } \\
\text { patients }\end{array}$ & $\mathrm{N}$ & $\mathrm{N}$ & $\mathrm{N}$ & $\mathrm{N}$ & $\mathrm{N}$ & $\begin{array}{l}\mathrm{N}(\mathrm{I} 1:-8 / \\
\mathrm{C} 1:+14)\end{array}$ & $?$ & $\mathrm{~N}$ & NA \\
\hline $\begin{array}{l}{[\mathrm{n}] \text { of sub- }} \\
\text { groups }\end{array}$ & NA & NA & NA & NA & 3 & NA & 2 & 1 & 3 \\
\hline $\begin{array}{l}\text { Sub- } \\
\text { groups: } \\
\text { pre- } \\
\text { defined }\end{array}$ & $\mathrm{N}$ & $\mathrm{N}$ & $\mathrm{N}$ & $\mathrm{N}$ & $\mathrm{Y}$ & $\mathrm{N}$ & 2 & $\mathrm{~N}$ & 0 \\
\hline $\begin{array}{l}\text { Sub- } \\
\text { groups: } \\
\text { post-hoc }\end{array}$ & $\mathrm{N}$ & $\mathrm{N}$ & $\mathrm{N}$ & $\mathrm{N}$ & $?$ & $\mathrm{~N}$ & 0 & $\mathrm{~N}$ & 3 \\
\hline
\end{tabular}

\begin{tabular}{|c|c|c|c|c|c|c|c|c|c|}
\hline $\begin{array}{l}\text { [n] of sta- } \\
\text { tis- } \\
\text { tical com- } \\
\text { parisons }\end{array}$ & $\begin{array}{l}\text { ca. } 13 \text {, to- } \\
\text { tal number } \\
\text { unclear }\end{array}$ & $\begin{array}{l}\text { at least } 12 \text {, } \\
\text { total num- } \\
\text { ber unclear }\end{array}$ & $\begin{array}{l}\text { at least } 13 \text {; } \\
\text { total num- } \\
\text { ber unclear }\end{array}$ & $\begin{array}{l}\text { ca. 8, to- } \\
\text { tal number } \\
\text { unclear }\end{array}$ & $\begin{array}{l}\text { at least } \\
45 \text { (includ- } \\
\text { ing sub- } \\
\text { groups), } \\
\text { total num- } \\
\text { ber unclear }\end{array}$ & $\begin{array}{l}24 \\
\text { reported in } \\
\text { paper, to- } \\
\text { tal number } \\
\text { unclear }\end{array}$ & $\begin{array}{l}\text { at least } 16 \\
\text { (without } \\
\text { subgroup } \\
\text { analyses); } \\
\text { total num- } \\
\text { ber unclear }\end{array}$ & ? & ? \\
\hline $\begin{array}{l}\text { Adjust- } \\
\text { ment for } \\
\text { multiple } \\
\text { outcomes / } \\
\text { repeated } \\
\text { measure- } \\
\text { ments }\end{array}$ & $\begin{array}{l}\text { ?, but pri- } \\
\text { mary effi- } \\
\text { cacy vari- } \\
\text { able } \\
\text { defined }\end{array}$ & $\mathrm{N}$ & $\mathrm{N}$ & $\mathrm{N}$ & ? & $\mathrm{N}$ & $\mathrm{N}$ & $\begin{array}{l}\text { Y (Bonfer- } \\
\text { roni) }\end{array}$ & $\mathrm{N}$ \\
\hline $\begin{array}{l}\text { Base- } \\
\text { line char- } \\
\text { acteris- } \\
\text { tics: Clin- }\end{array}$ & $\mathrm{N}$ & $\mathrm{N}$ & $\mathrm{N}$ & $\begin{array}{l}\text { Slight dif- } \\
\text { ferences re- } \\
\text { garding sex }\end{array}$ & $\begin{array}{l}\text { whole } \\
\text { study pop- } \\
\text { ulation : N } \\
\text { in- }\end{array}$ & $\mathrm{N}$ & $Y$ & $\begin{array}{l}\text { Dif- } \\
\text { ferences re- } \\
\text { garding } \\
\text { previous }\end{array}$ & $\begin{array}{l}\text { Slight dif- } \\
\text { ferences re- } \\
\text { garding sex }\end{array}$ \\
\hline
\end{tabular}




\begin{tabular}{|c|c|c|c|c|c|c|c|c|c|}
\hline $\begin{array}{l}\text { vant differ- } \\
\text { ences }\end{array}$ & & & & & $\begin{array}{l}\text { sulin naive } \\
\text { patients: Y } \\
\text { in- } \\
\text { sulin pre- } \\
\text { treated pa- } \\
\text { tients: Y }\end{array}$ & & & $\begin{array}{l}\text { use of beta- } \\
\text { blocker or } \\
\text { thiazide I1: } \\
71 \% \text { C1: } \\
63 \%\end{array}$ & \\
\hline $\begin{array}{l}\text { Treat- } \\
\text { ment iden- } \\
\text { tical (apart } \\
\text { from inter- } \\
\text { vention) }\end{array}$ & $\mathrm{Y}$ & $\mathrm{Y}$ & $\begin{array}{l}\text { higher } \\
\text { daily mean } \\
\text { doses of as- } \\
\text { part in the } \\
\text { detemir } \\
\text { group after } \\
26 \text { weeks - } \\
\text { I1: } 40 \text {, } \\
2 \text { IU/day / } \\
\text { C1: } 35.8 \\
\text { IU/day) }\end{array}$ & $\mathrm{Y}$ & ? & $?$ & ? & $\begin{array}{l}\text { ? (doses of } \\
\text { met- } \\
\text { formin) }\end{array}$ & $\begin{array}{l}\mathrm{N} \text { (only } \\
\text { glargine } \\
\text { group: } \\
\text { basal in- } \\
\text { sulin dose } \\
\text { in- } \\
\text { creased to } \\
50 \% \text { of to- } \\
\text { tal daily in- } \\
\text { sulin dose) }\end{array}$ \\
\hline $\begin{array}{l}\text { Timing of } \\
\text { outcomes' } \\
\text { measure- } \\
\text { ment com- } \\
\text { parable be- } \\
\text { tween } \\
\text { groups }\end{array}$ & $Y$ & $Y$ & $\mathrm{Y}$ & Y & $\mathrm{Y}$ & ? & $\mathrm{Y}$ & $\mathrm{Y}$ & $Y$ \\
\hline $\begin{array}{l}\text { Compli- } \\
\text { ance mea- } \\
\text { sured }\end{array}$ & ? & ? & ? & ? & ? & ? & ? & $\mathrm{Y}$ & ? \\
\hline $\begin{array}{l}\text { Other im- } \\
\text { portant co- } \\
\text { variates } \\
\text { measured } \\
\text { (specify) }\end{array}$ & ? & ? & ? & ? & $?$ & $?$ & ? & ? & ? \\
\hline $\begin{array}{l}\text { Co-mor- } \\
\text { bidities } \\
\text { measured }\end{array}$ & ? & ? & ? & $\mathrm{Y}$ & $?$ & ? & $?$ & $\mathrm{~N}$ & ? \\
\hline $\begin{array}{l}\text { Co-medi- } \\
\text { cations } \\
\text { measured }\end{array}$ & $?$ & ? & $\begin{array}{l}\text { Y } \\
\text { for aspart; } \\
\text { ? for fur- } \\
\text { ther medi- } \\
\text { cation }\end{array}$ & ? & ? & ? & ? & ? & $?$ \\
\hline $\begin{array}{l}\text { Specific } \\
\text { doubts } \\
\text { about }\end{array}$ & $\begin{array}{l}\text { No infor- } \\
\text { mation } \\
\text { provided }\end{array}$ & & $\begin{array}{l}\text { inconsis- } \\
\text { tencies be- }\end{array}$ & $\mathrm{N}$ & $\mathrm{Y}$ & $\begin{array}{l}\text { Inconsis- } \\
\text { tencies be- }\end{array}$ & $\begin{array}{l}\text { There is a } \\
\text { dif- }\end{array}$ & $\begin{array}{l}\text { There are } \\
\text { inconsis- }\end{array}$ & $\begin{array}{l}\text { There are } \\
\text { inconsis- }\end{array}$ \\
\hline
\end{tabular}




\begin{tabular}{|c|c|c|c|c|c|c|c|c|c|}
\hline $\begin{array}{l}\text { study qual- } \\
\text { ity }\end{array}$ & $\begin{array}{l}\text { about } \\
\text { the } 47 \text { pa- } \\
\text { tients ran- } \\
\text { domised } \\
\text { but not } \\
\text { treated }\end{array}$ & & $\begin{array}{l}\text { tween re- } \\
\text { ported and } \\
\text { calculated } \\
\text { (from fig- } \\
\text { ures given } \\
\text { in the pa- } \\
\text { per) values } \\
\text { for HbAlc } \\
\text { at } \\
\text { endpoint }\end{array}$ & & & $\begin{array}{l}\text { tween pa- } \\
\text { per and ab- } \\
\text { stracts } \\
\text { (posters) } \\
\text { published } \\
\text { elsewhere }\end{array}$ & $\begin{array}{l}\text { ference in } \\
\text { the num- } \\
\text { ber of re- } \\
\text { ported ran- } \\
\text { domised } \\
\text { pa- } \\
\text { tients (259 } \\
\text { in each } \\
\text { group) } \\
\text {, and the } \\
\text { sum of the } \\
\text { eth- } \\
\text { nically dif- } \\
\text { ferent par- } \\
\text { ticipants } \\
\text { (270 in the } \\
\text { glargine } \\
\text { group and } \\
267 \text { in the } \\
\text { NPH } \\
\text { group) }\end{array}$ & $\begin{array}{l}\text { tencies re- } \\
\text { garding } \\
\text { the HbAlc } \\
\text { value } \\
\text { at baseline } \\
\text { in the table } \\
\text { and in the } \\
\text { text. Infor- } \\
\text { mation re- } \\
\text { garding } \\
\text { the dose of } \\
\text { metformin } \\
\text { is only pro- } \\
\text { vided } \\
\text { in the ab- } \\
\text { stract pub- } \\
\text { lication. } \\
\text { Unclear } \\
\text { if doses of } \\
\text { metformin } \\
\text { were } \\
\text { similar be- } \\
\text { tween the } \\
\text { groups }\end{array}$ & $\begin{array}{l}\text { tencies re- } \\
\text { garding } \\
\text { the HbAlc } \\
\text { value in the } \\
\text { abstract } \\
\text { and the } \\
\text { text of the } \\
\text { trial. Un- } \\
\text { clear how } \\
\text { many par- } \\
\text { ticipants } \\
\text { received } \\
\text { OADs at } \\
\text { what dose, } \\
\text { frequency } \\
\text { and which } \\
\text { one }\end{array}$ \\
\hline $\begin{array}{l}\text { Fund- } \\
\text { ing: com- } \\
\text { mercial }\end{array}$ & Y & $Y$ & ? & $?$ & $Y$ & $\mathrm{Y}$ & ? & $\mathrm{Y}$ & $\mathrm{N}$ \\
\hline $\begin{array}{l}\text { Funding: } \\
\text { non-com- } \\
\text { mercial }\end{array}$ & $\mathrm{N}$ & $\mathrm{N}$ & $?$ & $\mathrm{~N}$ & $\mathrm{~N}$ & $\mathrm{~N}$ & ? & $\mathrm{N}$ & $\mathrm{N}$ \\
\hline $\begin{array}{l}\text { Publica- } \\
\text { tion status: } \\
\text { peer review } \\
\text { journal }\end{array}$ & Y & $Y$ & Y & $\mathrm{Y}$ & Y & $Y$ & Y & $Y$ & Y \\
\hline $\begin{array}{l}\text { Publica- } \\
\text { tion status: } \\
\text { jour- } \\
\text { nal supple- } \\
\text { ment }\end{array}$ & $\mathrm{N}$ & $\mathrm{N}$ & $\mathrm{N}$ & $\mathrm{N}$ & $\mathrm{N}$ & $\mathrm{N}$ & $\mathrm{N}$ & $\mathrm{N}$ & $\mathrm{N}$ \\
\hline $\begin{array}{l}\text { Publica- } \\
\text { tion status: } \\
\text { abstract }\end{array}$ & $\mathrm{N}$ & $\mathrm{N}$ & $\mathrm{N}$ & $\begin{array}{l}\text { previously } \\
\text { published } \\
\text { as abstract }\end{array}$ & $\mathrm{N}$ & $\mathrm{N}$ & $\mathrm{N}$ & $\begin{array}{l}\text { previously } \\
\text { published } \\
\text { as abstract }\end{array}$ & ? \\
\hline
\end{tabular}




\begin{tabular}{|c|c|c|c|c|c|c|c|c|c|}
\hline $\begin{array}{l}\text { Publica- } \\
\text { tion status: } \\
\text { other }\end{array}$ & $\mathrm{N}$ & $\mathrm{N}$ & $\mathrm{N}$ & $\mathrm{N}$ & $\mathrm{N}$ & $\mathrm{N}$ & $\mathrm{N}$ & $\mathrm{N}$ & $\mathrm{N}$ \\
\hline $\begin{array}{l}\text { Notes } \\
\text { N: no } \\
\text { Y: yes } \\
\text { OAD(s): } \\
\text { oral antidi- } \\
\text { abetic } \\
\text { drugs } \\
\text { SU: } \\
\text { sulphony- } \\
\text { lurea } \\
\text { ?: unclear } \\
\text { NA: not } \\
\text { applicable } \\
\text { FPG: fast- } \\
\text { ing plasma } \\
\text { glucose } \\
\text { FBG: fast- } \\
\text { ing blood } \\
\text { glucose }\end{array}$ & & & $\begin{array}{l}\text { the authors } \\
\text { state that } \\
\text { the study } \\
\text { had } 85 \% \\
\text { power to } \\
\text { de- } \\
\text { tect an av- } \\
\text { erage dif- } \\
\text { ference of } \\
0.4 \% \\
\text { in HBA1c } \\
\text { between } \\
\text { treatment } \\
\text { groups; } \\
\text { a per pro- } \\
\text { tocol anal- } \\
\text { yses is pre- } \\
\text { sented } \\
\text { in the FDA } \\
\text { medical re- } \\
\text { port; }\end{array}$ & & $\begin{array}{l}\text { ITT popu- } \\
\text { lation was } \\
\text { defined } \\
\text { as all per- } \\
\text { sons ran- } \\
\text { domised } \\
\text { and treated } \\
\text { and having } \\
\text { both a pre- } \\
\text { treatment } \\
\text { and on- } \\
\text { treatment } \\
\text { value. The } \\
\text { authors } \\
\text { also state } \\
\text { that the } \\
\text { size of this } \\
\text { popula- } \\
\text { tion was } \\
\text { different } \\
\text { for each } \\
\text { variable } \\
\text { but no } \\
\text { figures are } \\
\text { given for } \\
\text { the actual } \\
\text { patients } \\
\text { included } \\
\text { in the } \\
\text { different } \\
\text { analyses. } \\
\text { (Patients } \\
\text { random- } \\
\text { ized and } \\
\text { treated - } \\
\text { I1: 289 / } \\
\text { C1: 281). } \\
\text { The ITT } \\
\text { population } \\
\text { was used } \\
\text { to perform } \\
\text { analyses of }\end{array}$ & $\begin{array}{l}\text { The re- } \\
\text { ported } \\
\text { discontin- } \\
\text { uation rate } \\
\text { (I1: 9.0\% / } \\
\text { C1: 8.2\%) } \\
\text { is based on } \\
\text { the ITT } \\
\text { population } \\
\text { and does } \\
\text { not in- } \\
\text { clude pa- } \\
\text { tients who } \\
\text { were ran- } \\
\text { domised } \\
\text { but did } \\
\text { not receive } \\
\text { study } \\
\text { medica- } \\
\text { tion. Per- } \\
\text { centages } \\
\text { of discon- } \\
\text { tinuation } \\
\text { rate in this } \\
\text { table were } \\
\text { calculated } \\
\text { based on } \\
\text { all ran- } \\
\text { domized } \\
\text { patients }\end{array}$ & $\begin{array}{l}\text { Accord- } \\
\text { ing to the } \\
\text { EMEA re- } \\
\text { port a cen- } \\
\text { tralised, } \\
\text { comput- } \\
\text { erised tele- } \\
\text { phone ran- } \\
\text { domi- } \\
\text { sation was } \\
\text { used. A } \\
\text { higher per- } \\
\text { centage of } \\
\text { patients in } \\
\text { the NPH } \\
\text { group had } \\
\text { retinopa- } \\
\text { thy at base- } \\
\text { line }\end{array}$ & $\begin{array}{l}\text { There are } \\
\text { inconsis- } \\
\text { tencies re- } \\
\text { garding } \\
\text { the HbAlc } \\
\text { value } \\
\text { at baseline } \\
\text { in the table } \\
\text { and in the }\end{array}$ & \\
\hline
\end{tabular}


HbAlc,

FPG, FBG

and 24

hour blood

glucose

profiles.

The safety

population

included

all $\quad 570$

random-

ized and

treated

patients.

It remains

unclear

what

parameters

(hypogly-

caemia)

were

analysed

based on

this pop-

ulation.

There is no

statement

concern-

ing spon-

sorship

in the

paper by

Massi. Yki-

Järvinen in

her paper

on the

results for

the insulin

naive

patients

informs

us that

the study

was com-

mercially

sponsored 


\section{F E E D B A C K}

\section{Comment to the protocol by Horvath}

\section{Summary}

Page 1: The general statement "evidence for the beneficial effect of antihyperglycemic therapy is conflicting" is out of date. It is generally accepted that microvascular complications are reduced by effective glycaemic control in diabetes type 2 , and there is increasing evidence for reduction of macrovascular complications if glycaemic control is established early in the course of the disease (published type 1 diabetes, ongoing large clinical studies in type 2 diabetes). There is no evidence "that different interventions carry different substance specific beneficial or adverse effects". Establishing glycaemic control in diabetes type 2 is the essential element of preventing microvascular and macrovascular complications [by early insulin therapy, in suitable clinical conditions by oral antihyperglycemic agents, and by combination treament]. The substance specific beneficial or adverse effects of the two classes of compounds (insulins versus oral antidiabetic drugs, OAD) are entirely different. Within the pharmacological group of insulins, differences are related more to the dosage form (immediate acting insulin or intermediate acting insulin) than to the specific substances (animal insulins, human insulin or insulin analogues).

The statement "firm conclusions on the effect of interventions on patient relevant outcomes cannot be drawn from the effect.... on blood glucose concentrations alone" is ambiguous because treatment to glycaemic targets is the primary objective in type 2 diabetes, the effect of achieving glycaemic control on microvascular complications is firmly established.

The statement "insulin in itself is a group of heterogeneous preparations" needs to be changed to "the insulin drug substance is used in a number of presentations of different duration of action".

Page 2: It is useful to extend the definition of insulin analogues "changing the amino acid sequence, and the physicochemical properties", because the essential element is delayed absorption due to the physicochemical change.

The definition of insulin glargine needs to iinclude "which is less soluble at the injection site, and forms an amorphous precipitate in the subcutaneous tissue which is gradually absorbed (Sandow et al 2003)". Glargine does not form crystals or microprecipitates as quoted in outdated reviews.

The statement in the last paragraph refers to human insulin as well as insulin analogues and can be worded "structural homology of human insulin to insulin like growth factor (IGF-I) has caused concern...” because the findings with high (supraphysiological) doses of human insulin in experimental preclinical studies indicate that human insulin has mitogenic activity which is dose-related, when animals are treated with excessive doses of human insulin may cause effects similar to those of IGF-I [EPAR].

The references that "IGF-I may affect the progression of retinopathy" need to be updated in view of the clinical consensus that progression of retinopathy is related to the rapid normalisation of glycaemic control, whereas the systemic and local factors involved in progression of retinopathy are not completely resolved. The specific effect of IGF-I in clinical studies (Thrailkill et al 1999 ) on formation of macular edema is not found with insulin analogues.

The statement "modified insulin analogues have shown a carcinogenic effect in the mammary gland of female rats" is not correct, there is only one fast acting insulin analogue [B10-Asp]-insulin which has shown such an effect and was subsequently used as the comparator for all new insulin analogues. >From the publication of Kurtzhals 2000 it is evident that all clinically used insulin analogues differ from [B10-Asp]-insulin (which has markedly prolonged residence time on the insulin receptor) by a (rate of dissociation which is similar to human insulin or even shorter. It cannot be justified to quote the evidence for the current insulin analogues in this rudimentary form. No preclinical evidence has been brought forward for the "potentially adverse properties of insulin analogues", on the contrary extensive clinical testing and post-marketing surveillance reporting has shown no evidence for either increased mitogenic efficacy in patients, or for progression of retinopathy and related events (retinal bleeding).

The proposed aim of the Cochrane review is to review clinical efficacy and safety. In this context, reference to the "increased mitogenic potential" should be discontinued because the scientific evidence has been evaluated by the competent authorities (EMEA and FDA), and periodic safety updates are evaluated which do not provide evidence or support the contentions of "increased mitogenic potential" in the therapeutic dose range used for both type 1 diabetes and type 2 diabetes.

The inclusion criteria for studies with combination therapy should clearly state "long acting analogue combined with other antihyperglycaemic drugs", and should not be limited to combination with one antihyperglycaemic drug, because the clinical study protocols frequently included more than one orally active antihyperglycaemic drug. There are also studies comparing combination treatment (NPH insulin plus OAD vs. long acting insulin analogue alone). Excluding such studies from the evaluation would create unnecessary bias and loss of evidence. The clinical relevance of combination treatment reflects the reality of present-day therapy. Comparing basal insulin therapy alone with combination therapy in RCT-24 studies is important for EBM assessment.

Long-acting insulin analogues versus NPH insulin (human isophane insulin) for type 2 diabetes mellitus (Review) 
The statement "only studies reporting on insulin regiments (schemata) with subcutaneous application" should be omitted because the two long acting insulin analogues to be reviewed are approved for subcutaneous application only, both are contraindicated and unsuitable for CSII due to their physicochemical properties.

Page 3: In the primary outcome measure, it is surprising to find hypoglycaemia events first followed by glycaemic control. The clinical evidence is clearly that improving and maintaining glycaemic control is the key objective in type 2 diabetes (as well as in type 1 diabetes). Prevention or a delay of progression of microvascular and macrovascular complications follows from treatment to close hypoglycaemic targets, as defined by IDF, ADA and National Diabetes Societies. The key issue is whether glycaemic control can be achieved to the same extent as by conventional NPH insulin, and whether the risk of hypoglycaemic events can be reduced by new treatment regimens, using long acting insulins alone, combination with orally active antidiabetic drugs (OAD), and early insulinisation.

For the secondary outcome measure, it is suggested to evaluate first the evidence for reduced microvascular complications. This may be followed by evaluation of reduction of macrovascular complications, for which supporting evidence from studies of "duration of 24 weeks or longer" (Page 2) cannot be expected at the present time, because longer observation periods are clearly required, as is wellestablished from similar long term observations in diabetes type 1.

References: Concerning the "additional references" on pages 6 and 7 of the protocol, it is suggested to update this reference list considerably because much of the recent evidence for effective treatment of type 2 diabetes and related studies in type 1 diabetes and the effect on microvascular/macrovascular complications needs to be included.

It is proposed to omit reference to the "increased mitogenicity" arguments, or to include an updated and comprehensive discussion of the topic with relevant contemporary references. [Reference and reprints forwarded by separate ma

\section{Reply}

Many thanks for your comments on this important topic.

Regarding the first comment, we will not make any changes because our interpretation of the statement that the "evidence for the beneficial effects of antihyperglycaemic therapy is conflicting" is based on the currently published results of randomised controlled trials dealing with drugs that lower blood glucose.

According your suggestions, we will extend the definition of insulin analogues and provide a more precise definition of insulin glargine. Though the content of the paragraph about carcinogenicity and mitogenic potency is correct, we have rephrased it to make it more comprehensive.

Our review will aim to assess advantages or disadvantages of long-acting insulin analogues as compared to NPH insulin. To detect any differences between both treatment arms any additional anti hyperglycaemic agents have to be part of each treatment group.

We do not understand the comment that our statement "only studies reporting on insulin regimens with subcutaneous application" should be omitted because e.g. studies using inhalative insulin as additional treatment in both groups will be excluded as well.

Concerning the criticism of the ranking of our outcome measures, it was the decision reached by consensus of all protocol authors in terms of patient-relevant endpoints.

\section{Contributors}

Prof Dr Juergen Sandow. Submitter has modified conflict of interest statement: I am a member of the diabetes research group at Sanofi Aventis.

\section{RESPONSE TO HORVATH et al.}

\section{Summary}

Horvath et al. concluded their review with the following statement "If at all, only a minor clinical benefit of treatment with longacting insulin analogues (LAIA) for patients with diabetes mellitus type 2 treated with "basal" insulin regarding symptomatic nocturnal hypoglycaemic events. Until long-term efficacy and safety data are available, we suggest a cautious approach to therapy with insulin glargine or detemir."

We believe this interpretation is overly critical of the long-acting analogues, and fails to take into consideration some important points. Defined as a "minor clinical benefit", the consistent finding of reduced risk of hypoglycaemia with LAIA reflects the authors' preconceived bias that contradicts the very essence of the Cochrane reviews, and it disregards the importance of hypoglycaemia in

Long-acting insulin analogues versus NPH insulin (human isophane insulin) for type 2 diabetes mellitus (Review) 
clinical diabetes. Firstly, hypoglycaemia is not a trivial problem from the point of view of many patients and physicians, and is a leading barrier to effective use of insulin.

The widespread use of both glargine and detemir has occurred in part due to the experience, both in studies and in clinical practice, that hypoglycaemia is reduced when they are used instead of human intermediate insulins. However, the authors counter this beneficial effect of LAIA in their discussion, using the argument that there is a possibility of bias because the studies were not blinded. Although lack of blinding is a conventional objection that might have influenced hypoglycaemia reporting, measurements of glucose confirming hypoglycaemic events are quite objective and less likely to be affected by lack of blinding of treatment. In fact, blinding was not possible owing to the cloudy physical characteristics of NPH and the clear nature of the soluble LAIAs that have consistently shown less frequent hypoglycaemic events.

Secondly, with regards to the methodology of the paper, most of the studies selected were equivalence studies or non-inferiority trials performed as required for regulatory approval. Thus, not surprisingly, if the hypothesis that preceded the meta-analysis was to demonstrate HbA1c superiority of LAIAs over NPH, this was not found because it was not the intent, nor was it in concordance with the objective of the majority of the published study data used for the analysis. Moreover, the differences in hypoglycaemia observed between human insulins and insulin analogues are greater as glycaemic control approaches the usual target levels, HbA1c 7.0 or $6.5 \%$. Non-inferiority studies generally do not aim to optimize control, and therefore may minimize this advantage. A statistical analysis of this problem of interpretation has recently been published (Mullins et al, 2007) and is very relevant to the conclusions of the metaanalysis. A leading point is that when rates of hypoglycaemia are adjusted for baseline or achieved HbAlc levels, differences between human insulin and analogues become more apparent.

Thirdly, the authors stated that "no trial reported data on quality of life". We believe this is misleading and inaccurate, as aspects of quality of life, such as treatment satisfaction, have been reported at various congresses with full reports in progress. Data sets would have been fully available from the sponsors had the authors requested them. Their findings are consistent with the study by Eliaschewitz, which is cited in the review.

Finally, the secondary endpoints of the meta-analysis were mortality/cardiovascular morbidity/diabetic late complications. The studies analysed did not aim to investigate these variables and their duration was not long enough to take these into consideration. Even though the authors acknowledge this in their discussion, they still conclude that no important improvements in the development of microvascular complications would be expected from treatment with LAIAs. This is correct because there is no reason to believe that these new insulins should have any intrinsic or direct effect to benefit complications. What it is incorrect is to advise caution in the conclusion when using LAIA. Caution implies by definition "avoiding danger or harm; close attention or vigilance to minimize risk". We think this advice is premature, and the evidence for potential harm is scanty and should not have been given a place in their conclusion. Any strong remarks or recommendations based on theoretical risks of LAIAs should await completion of ongoing outcome studies on retinopathy and cardiovascular parameters, and results fully analyzed and published.

In conclusion, we believe the clinical benefits of LAIA over NPH insulin are more than "minor" in many situations, and that the advice to use LAIAs with "caution" is not warranted and is inappropriate on the basis of existing findings. Long-acting insulin analogues are widely used tools that have facilitated insulin management to achieve glycaemic control more safely and more predictably with significantly less risk of hypoglycaemia, allowing more active self-titration by patients with type 2 diabetes. Ongoing studies will provide more complete answers to the questions about long-term risks and benefits of these agents, and will allow more definitive conclusions. References

Mullins P, Sharplin P, Yki-Jarvinen H, Riddle MC, Haring HU. Negative binomial meta-regression analysis of combined glycosylated hemoglobin and hypoglycemia outcomes across eleven Phase III and IV studies of insulin glargine compared with neutral protamine Hagedorn insulin in type 1 and type 2 diabetes mellitus. Clin Ther 2007; 29: 1607-1619.

\section{Reply}

We thank Drs. Rosenstock, Fritsche and Riddle for their interest in our review and their comments.

We agree that hypoglycaemia is indeed an important clinical problem affecting the wellbeing and treatment satisfaction of patients, and the extent to which blood glucose concentration can be lowered. Indeed, the effectiveness of insulin therapy can only be evaluated by considering HbA1c change and the corresponding number of hypoglycaemic events together. The fact that we considered hypoglycaemia as being of high importance is also reflected by the fact that we chose the "number of overall, severe and nocturnal hypoglycaemia" (along with HbA1c) as our primary endpoint.

Also it seems that those same considerations were the basis for conducting the non-inferiority trials at hand: with the same efficacy in reducing HbA1c (non-inferiority) an additional benefit of reduced hypoglycaemic events was expected. Since for our review lowering $\mathrm{HbA1c}$ was not the sole crucial endpoint, but corresponding hypoglycaemia rates were considered as important, the inclusion of noninferiority trials does not undermine the conclusions that can be drawn from our results.

Long-acting insulin analogues versus NPH insulin (human isophane insulin) for type 2 diabetes mellitus (Review) 
At any rate, it is essential that the studies were conducted in such a way, that results could be considered largely as unbiased. Among those items that determine the methodological quality of trials is blinding of patients and caregivers for treatment.

It is true that blinding was not feasible in the studies comparing insulin glargine or detemir with NPH-insulin. However, the simple fact that patients and caregivers were not blinded, does raise the risk for bias regardless of whether blinding would have been possible or not. Also in a situation where blinding is not possible or feasible, other precautionary measures, such as adequate concealment of allocation, blinding of endpoint assessment or unequivocal definitions of endpoints have to be taken to minimize the chance for bias. In most of the included studies either this was not done or not reported (see also Table 03 "Study quality" and Table 07 "definition of hypoglycaemia in study as reported"). Also, the lack of blinding was not the only item leading us to conclude that methodological quality was insufficient to rule out bias. Thus, from the information which is available to us, we have to conclude that the results are open for bias.

"Quality of life" is a multidimensional construct. While quality of life and health status instruments are measuring the outcomes of treatment, treatment satisfaction instruments assess the level of satisfaction with health status outcomes (Revicki 2008). Differentiating between these two concepts, the published trials did not provide any information on aspects of quality of life. However, we still reported the results on treatment satisfaction.

We also contacted all authors of the included studies, among them Drs. Rosenstock, Riddle and Fritsche, asking for additional information. Not all responded. Among those who did was Dr. Riddle. In his letter he told us, that although he had the information we were asking for, he was not able to disclose them to us, because it was the property of Sanofi-Aventis. We also contacted the producers of long-acting insulin analogues "Sanofi-Aventis" and "Novo Nordisk". In the answering letter from Sanofi Aventis (Dr. Vaur) we were told: "With respect to this request I must unfortunately inform you that our company policy is to not provide any third parties with our confidential information such as, e.g. unpublished information contained in study reports or study databases." We did not receive an answer from Novo Nordisk. In contrast, some authors did provide us with additional data which we incorporated in the review we also acknowledged this wherever applicable.

For insulin therapy in diabetes mellitus, NPH is an effective, safe substance which has been tested over decades. In such cases where a proven effective therapy is available, the introduction of new substances should only be advised if there is a major improvement in efficacy, or if the new substance is proven both effective and safe. Introducing new substances while safety issues are still unanswered could result in harm to patients, as the examples of rosiglitazone, vioxx and others show. So, our advocacy of a cautious approach to therapy with long-acting insulin analogues at this time is justified.

Karl Horvath

Klaus Jeitler

Andrea Berghold

Susanne Ebrahim

Thomas W. Gratzer

Johannes Plank

Thomas Kaiser

Thomas R Pieber

Andrea Siebenhofer

(Revicki DA. Patient assessment of treatment satisfaction: methods and practical issues. GUT online 2008.)

\section{Contributors}

Julio Rosenstock, Andreas Fritsche, Matthew Riddle

Submitter has modified conflict of interest statement:

Julio Rosenstock has received grants for research from and/or has been a consultant to Amylin, Boheringer-Ingelhein, Bristol-Myers Squibb, Centocor, Eli Lilly, Emisphere, GlaxoSmithKline, Johnson \& Johnson, MannKind, Merck, Novartis, NovoNordisk, Pfizer, Roche, Sankyo, sanofi-aventis and Takeda. Andreas Fritsche has received honoraria for lectures from sanofi-aventis, MSD, NovoNordisk and Bayer. Matthew Riddle has received grant/research support from Amylin, Eli Lilly and sanofi-aventis, has been a consultant to Amylin, Eli Lilly, NovoNordisk, sanofi-aventis and Valeritas, and has received lecture honoraria from Amylin, Eli Lilly and sanofiaventis

Long-acting insulin analogues versus NPH insulin (human isophane insulin) for type 2 diabetes mellitus (Review) 


\section{WHAT'S NEW}

Last assessed as up-to-date: 10 December 2006.

Date Event Description

17 August 2009 Amended missing author added (Thomas Kaiser)

\section{H I S T O R Y}

Protocol first published: Issue 1, 2006

Review first published: Issue 2, 2007

\section{CONTRIBUTIONSOFAUTHORS}

Karl Horvath: protocol development, quality assessment of trials, data extraction, development of final review, corresponding author

Klaus Jeitler: protocol development, searching for trials, quality assessment of trials, data extraction

Andrea Berghold: protocol development, statistical analysis, development of final review

Johannes Plank: development of final review

Thomas Pieber: protocol design

Andrea Siebenhofer: protocol development, quality assessment of trials, data extraction, development of final review

Thomas Kaiser: protocol development

Susanne Ebrahim: trial selection, data extraction, development of final review

Thomas W. Gratzer: quality assessment of trials, data extraction

\section{DECLARATIONSOF INTEREST}

Karl Horvath, Klaus Jeitler, Thomas W. Gratzer, Johannes Plank and Andrea Siebenhofer are part of a research group who performed several studies in short and long-acting insulin analogues with the companies Sanofi-Aventis, Eli Lilly and Novo Nordisk. Thomas R. Pieber was or is currently a paid consultant for these companies. All the authors, except Johannes Plank and Thomas R. Pieber were involved in the preparation of a report on the effects of long-acting insulin analogues versus other basal insulins in the therapy of patients with type 1 and type 2 diabetes mellitus for IQWiG, the German Institute for Quality and Efficiency in Health Care. Susanne Ebrahim and Thomas Kaiser are employees of IQWiG.

Long-acting insulin analogues versus NPH insulin (human isophane insulin) for type 2 diabetes mellitus (Review) 


\section{SOURCES OF SUPPORT}

\section{Internal sources}

- Department of Internal Medicine, University Hospital Graz; Institute for Medical Informatics, Statistics and Documentation, University of Graz, Austria.

\section{External sources}

- Institute for Quality and Efficiency in Health Care (IQWiG), Germany.

\section{N D EX TERMS}

\section{Medical Subject Headings (MeSH)}

Diabetes Mellitus, Type 2 [*drug therapy]; Hypoglycemic Agents [ ${ }^{*}$ therapeutic use]; Insulin [analogs \& derivatives; therapeutic use]; Insulin, Isophane [*therapeutic use]; Insulin, Long-Acting [*therapeutic use]; Randomized Controlled Trials as Topic

\section{MeSH check words}

Humans 